Florida International University FIU Digital Commons

$10-3-1979$

\title{
International tourism : is this the answer to Jamaica's developmental problem?
}

Geli M. Eldemire

Florida International University

DOI: $10.25148 /$ etd.FI15101286

Follow this and additional works at: https://digitalcommons.fiu.edu/etd

Part of the Hospitality Administration and Management Commons, and the Tourism and Travel Commons

\section{Recommended Citation}

Eldemire, Geli M., "International tourism : is this the answer to Jamaica's developmental problem?" (1979). FIU Electronic Theses and Dissertations. 3134.

https://digitalcommons.fiu.edu/etd/3134 


\title{
INTERNATIONAL TOURISM: IS THIS THE ANSWER TO JAMAICA'S DEVELOPMENTAL PROBLEM?
}

\author{
by
}

Geli M. Eldemire

\begin{abstract}
A thesis submitted in partial fulfillment of the requirements for the degree of MASTER OF SCIENCE in

HOTEL AND FOOD SERVICE MANAGEMENT

at

FLORIDA INTERNATIONAL UNIVERSITY
\end{abstract}

Committee in charge:

Professor William J. Morgan, Jr. Chairperson Asst. Prof. Norman Hall 
To: Professors William J. Morgan, Jr.

Asst. Professor Norman Hall

This thesis, having been approved in respect to form and mechanical execution, is referred to you for judgment upon its substantial merit.

Dean Gerald W. Lattin School of Hospitality Management

The thesis of Geli M. Eldemire is approved.

Assistant Professor

Major Professor

Date of Examination:

$$
101319
$$


INTERNATIONAL TOURISM: IS THIS THE ANSWER JAMAICA'S DEVELOPMENTAL PROBLEM?

by

Ge1i M. Eldemire

A thesis submitted in partial fulfillment of the requirements for the degree of

MASTER OF SCIENCE

in

HOTEL AND FOOD SERVICE MANAGEMENT

at

FLORIDA INTERNATIONAL UNIVERSITY

1979 
International Tourism:

Is This The Answer To Jamaica's Developmental Problem

by

Geli Eldemire

The years since World War II have witnessed a rapid growth in International Tourism consequent on improved technologies, increased affluence and leisure time in developed nations. Many of the poorer third World Nations lacking major marketable resources have opted for tourism as a developmental strategy hoping to draw some of the "free-spending" visitors to their shores thereby reducing the World's unequal distribution of wealth.

Tourism promises beneficial effects such as the generation of urgently needed foreign exchange, employment and promotes overall economic growth.

The objective of this thesis is to present information on the contribution of tourism when compared to the other major industrial sectors in Jamaica, in order to assist the island's planners in the decision as to whether or not tourism can be relied on to provide the economic development needed. In addition, to suggest possible strategies and areas for improvement to derive increased benefits from tourism while minimizing the negative impacts.

The data for this paper comes from primary sources such as government publications and secondary sources mainly hospitality industry literature.

Tourism can be an effective method of earning foreign exchange with proper planning and foresight to reduce to minimum tourism's negative impacts. Jamaica should carefully choose between a mere quantitative market expansion, the "mass" market or a "fewer but better" tourist market, the "class" market. The specific market chosen will determine the economic and social implications on the country and the type of facility planning necessary. Jamaica needs also to revitalize the tourist industry to build on its uniqueness, improve services and employee attitudes while indulging in a balanced policy of import substitution. 
Acknowledgement

A paper of this nature involving aspects of International Tourism, the Caribbean and Janaica could not have been completed successfully without the assistance and cooperation of many individuals.

Foremost among the people to whom $I$ am indebted is Doctor William Morgan, my chief advisor on this thesis. This truly gentle man has guided my learning in Hospitality Management from my very first semester at Florida InternationaI University when I was accidentally enrolled in two of his graduate courses. Through his encouragement, patience and friendship he has made the completion of this thesis a reality.

Special thanks to the Trade Commissioner at the Jamaican Consulate, Denzil Miles, to Professor Huse, Professor Darby and Professor Hall for making available to me their special collection of books, papers, articles and notes on Tourism and the Caribbean. In Professor Hal1, my other committee advisor, I found a friend who is always willing to $l$ isten and have time to talk.

Thanks to my sister-in-1aw, Monica West Mitchel1, Reynold Scott of Jamaica and Druscilla from the Bahamas for their generous assistance in the Research and collection of materials for this thesis and to my secretaries, Grace and Natalie, for the time they devoted to typing this paper for presentation. 


\section{Table of Contents}

List of Tables

Page

vi

List of figures.................. ix

Introduction

$\cdot \mathrm{x}$

Objectives

xii

Chapter I - Tourism and the Demand for Travel . . 1

A Brief History of Tourism . . . . . . . . . . I 1

Trends in International Tourism . . . . . . 7

Tourism in Developing Countries . . . . . . . 19

Who is a Tourist? . . . . . . . . . . 21

Motives for Trave1.......... . 22

Chapter II - The Caribbean Economies and Jamaica . 29

An Introduction to the Structure of the

Caribbean Economies: Location 29

History .. . . . . . . . . . . 30

Effects of Migration . . . . . . . . 35

Political Situation . . . . . . . . . . 36

Economic Situation .. . . . . . . . 37

Social Situation . . . . . . . . . . 39

Jamaica . . . . . . . . . . . . . 43

Population ............. . . . 44 4

The Economy . . . . . . . . . . . 48

Tourism in the Caribbean .. . . . . . . 50

Definition of Tourism . . . . . . . . 51

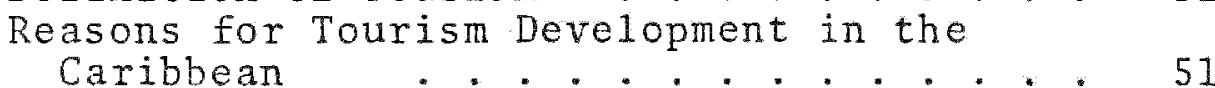

Trends in Tourism Development in the

Caribbean . . . . . . . . . . . 54

Who is the Tourist to the Caribbean. . . 65

Chapter III - The Sectoral Contributions of Janaica's Major Industries to Overall Development 68

The Economy . . . . . . . . . . . . . 68

External Trade.............. 77

Imports . . . . . . . . . . . . 82

Domestic Exports . . . . . . . . . 86 
Consumer Prices... . . . . . . . . . 92

Agriculture . . . . . . . . . . . 93

The Mineral Industry .. . . . . . . . . 102

Discovery and Development........ . 102

Performance of the Bauxite/Alumina Industry 107

Industrial Materials . . . . . . . . 115

Manufacturing . . . . . . . . . 116

Performance ............. 116

Problems Encountered in the Industry : : 116

Construction and Installation . . . . . . 121

Cement .............. 121

Steel ............... 122

Other Local Materials... . . . . . 122

Contribution of the Industry . . . . . . 124

Tourism

Introduction . . . . . . . . . . . 125

Performance of the Industry . . . . . . 127

Contribution of the Industry . . . . . 136

Chapter IV - The Structure of the Industry as it Exists in Jamaica ......... 142

Criticisms of the Tourist Industry..... . 142

Structure of the Industry in Jamaica.... . 143

The Economic Impact . . . . . . . . . . 149

The Socio-Cultural Impact . . . . . . . 153

Tourism Causes Social Tensions...... . 155

Tourism Causes a Decline in Local Customs . . 156

Tourism Causes Class Tensions . . . . . . 158

Political Impact . . . . . . . . . . 159

Environmental Impact . . . . . . . . . 161

Chapter V - Summary and Conclusions . . . . . . 163

Recommendations ........... . 182

Choose the Tourist Market Carefully . . . 182

Need to Revitalize the Industry . . . . . 186

Improvement of Services......... 187

Government Incentives to Tourism . . . . 188

Domestic Tourism . . . . . . . . . . . 189

Import Substitution. . . . . . . . . . 189

Conclusion . . . . . . . . . . . . . 191 
Page

Selected Bibliography . . . . . . . . . . . 192

Books and Collections of Papers . . . . . 192

Articles and Published Papers . . . . . . 193

Reports, Unpublished Papers, Government

Publications and Other Sources... . . . 196

Vita ................... 198 
Chapter I

1. International Tourist Arrivals and Receipts, 1958-1976

2. Effect of Two Year Recession on World Tourism

3. International Tourist Arrivals 1950 , 1960 and 1970 by Regions

4. Growth in U.S. Per Capita Disposable

Personal Income, 1950-1975

5. United States Passports Issued and Received 1960-1977 by Calendar Year

6. Departure of U.S. Citizens by Air to Selected Areas 1961-1975

7. World Airline Statistics

8. The Growth of International Tourism in the Developing Countries 1962-1973

9. The Share of Developing Countries in World Trade and in International Tourism 19621973

Chapter II

1. Natural Increase and Net Migration in the Commonwealth C.A., 1950-1970

2. Migration in Puerto Rico 35

3. Demographic Statistics 44

4. Caribbean Visitors Arriving by Air 59

5. Arrivals of Cruise-Ship Passengers in

Selected Countries, 1970-1977 60

6. Foreign Exchange Earnings from Tourism 62

7. Contribution of Travel Earnings to Balance Payments, Selected Years

Chapter III

1. Gross Domestic Product 72

2. Income Distribution 73

3. Gross Domestic Product by Economic Activity in Purchasers' Values at Constant Prices 
Chapter III (cont'd)

4. Rate of Growth of Gross Domestic Product by Industrial Sectors at Constant Prices

$\underline{\text { Page }}$ 75

5. Percentage Contribution of Gross Domestic Product by Industrial Sectors at Constant Prices

6. Externa1 Trade for 1977 and 1978

7. Rate of Exchange

8. Total External Trade, 1938, 1948, 1958-1977, by Quarters 1975-1977

9. Foreign Debt and Net Exchange Reserves

10. Annual Changes in Total Imports: 1960-1978 83

11. Imports by Economic Function or End-Use $1975-1977$

12. Raw Material Imports 1975-1977

13. Value of Imports at Exchange Rate Existing Dec. 31, 1978

14. Domestic Exports 1960-1977

15. Value and Percentage Distribution of Tota1 Domestic Exports 1975-1977

16. Major Exports-at Exchange Rate Existing Dec. 31, 1978

17. Value of Exports - at Exchange Rate Existing Dec. 31,1978

18. Value of Imports from Principal Countries $1975-1977$

19. Value of Domestic Exports to Principal Countries 1975-1977

20. Land Use Distribution

21. Distribution of Land in Farm by Major Types of Use, 1968

22. Volume of Agricultural Production: 1973-1977

23. Sugar Cane Acreage Reaped and Tonnage per Acre: $1972-1977$

24. Domestic Exports of Sugar and Banana 1955-77

25. Ownership in the Jamaican Bauxite/Alumina Industry 
26. Target and Actual Output of Bauxite and Alumina

108

27. Bauxite and Alumina Production: 1973-77

109

28. Bauxite Production by Selected Countries as a Percentage of Total World Production

29. Domestic Exports of Bauxite and Alumina $1955-1977$

30. Payment of Production Levy and Royalties by Bauxite and Alumina Companies to the Government of Jamaica

31. Employment - Mining and Quarrying 1974-77

32. Production of Industrial Minerals 1974-77

33. Classifiable Labor Force and Employment in Manufacturing: 1974-1977

34. Production and Sales of Cement 1973-1977

35. Output and Sales of Steel for 1973-1978

36. Composition of Fixed Capital Formation by Type of Capital Goods

37. Labor Force and Employment in Construction $1974-1977$

38. Stop-Over Visitors on Annual Basis

39. Total Visitors to Jamaica: 1964-1978

40. Visitor Accommodation: 1970-1977

41. Downward Trend in Hotel Occupancy Rate 1968-1977 - Jamaica

42. Number of Jamaican Guests in Hotels 1976-1977

43. Government Ownership of Hotel Rooms 1977

44. Ownership of Hotel Rooms at January 1978

45. Receipts from Tourism 1972-1978 137

46. Earnings from Tourism as a Percentage of Gross Domestic Product

.47. Major Export Items to Total Exports,1972-77

48. Employment in Visitor Accommodation in Jamaica for 1971-1977 
List of Figures

Chapter II I

Page

1. Import and Export Volume Indices 1969-1977

81 


\section{INTRODUCTION}

In the past two decades, International Tourism has surfaced to become a development tool in the less advanced nations of the World. Governments of these countries responsible for the economic welfare of their people lacking capital, mineral resources and valuable sources of energy, while possessing natural tourist attractions and salubrious climates have embraced tourism as a vehicle of national development and a possible solution to their dilemma.

With the first eagerness for the tourist dollar came wholesale tourism development in these countries by invitation and concessions. These countries were aided in commencing these intensive tourism development programs by the period of prosperity in the 1960's, improved standards of living and technologies existing in the more advancod countries. The coming of the Jet Age and charter flights, increased demand for leisure and acceptance of paid vacations as a way of life. The lifting of travel restrictions also which together accounted considerably for their success in attracting tourists from developed World Urban Centers.

Tourism promised beneficial effects in the generation of employment of the unskilled which is abundant in developing nations; large Foreign Exchange receipts to reduce outstanding balance of payment deficits, and the redistribution of income both on a World wide and National scale. It caused no reduction in the country's natural resources in the same way that the traditional production of goods does. At the same time it places revenue in the government coffers in the form of taxation. 
Considering the amount of resources funneled into its development, tourism must justify its existence by demonstrating to the people of these countries that the socio-economic benefits derived from the industry far outweigh the costs involved. Increasingly the tourist industry is being challenged to prove itself in the third world developing countries. In the introduction to E.F. Schumacher's Small is Beautiful, Theodore Roszak wrote:

"Consider the poor countries that sell themselves to the international tourist industry in pursuit of those symbols of wealth and progress the West has taught them to covet: Iuxurious airports, high-rise hotels, six-lane motor lanes. Their people wind up as bellhops and souvenir sellers, desk clerks and entertainers, and their proudest traditions soon degenerate into crude caricatures. But the balance sheet may show a marvelous increase in foreign exchange earnings."(1)

And as Louis Turner stated in The Golden Hordes:

"Those individuals who are drawn into the service industry may make a temporary financial gain, but it is arguable that they will lose in culture and psychological terms whatever they may gain financially. It is necessarily difficult for a nation of waiters, barmen, guides, hustlers and prostitutes to retain any sense of dignity or identity."(2)

Tourism once viewed as the 'smokeless industry' which could stimulated economic development and generate income and employment is today being weighed more carefully in terms of the cost-benefits.

${ }^{1}$ Theodore Roszak, Introduction to Small is Beautiful: Economics as if People Mattered, by E.F. Schumacher (New York: Harper and Row, 1973)

${ }^{2}$ Louis Turner and John Ash, The Golden Hordes: International Tourism and the pleasure pheriphery, p. 198. 
As George Doxey remarked "at the time we were more preoccupied with these economic questions and less conscious of the sociological aspects of development," as they were economists. ${ }^{1}$

One can question what is development. Is the acquiring of al1 the outer symbols existing in developed countries development? The large scale construction of high-rise condominiums, resort hotels and airports is not development. Development includes but is not exhausted by:

1. balanced economic growth;

2. price stability;

3. balance of payment equilibrium;

4. adequate medical care;

5. provision of a sanitary environment;

6. 1ow unemployment rates;

7. various labor opportunities to match diverse individual talents; (2)

8. a chance to acquire skills and develop the mind;

9. a sense of inner security and safety;

10. adequate housing;

11. economic production systems that are in balance with the environment; and

12. equality in social and political settings, where differentation by class, sex, color, wealth and religion is absent, or at least not degrading.(3)

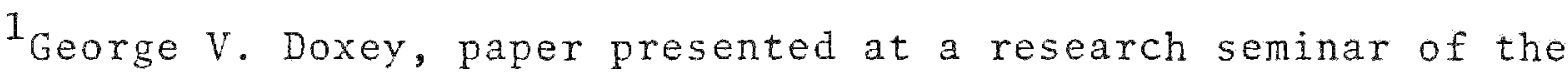
Pacific Area Trave1 Association, Suva, Fiji, 15-19 October 1973.

${ }^{2}$ Anthony R. Desouza and Phillip W. Porter, The Underdevelopment Modernization of the Third World, (Washington: Commission on College Geography Association of American Geographers, 1974), pp. $3-4$.

3 Ibid. 
The purpose of this study is:

1. to seek to assess the effect of international tourism as a developmental strategy on the Jamaican economy;

2. to examine the advantages and disadvantages of tourism and tourism's comparative performance measured against the other sectors such as mining, agriculture and 1 ight manufacturing industries' its failures, successes and contribution to the Gross National output, Foreign Exchange earnings, employment and overall national development.

The tourist industry in Jamaica normally, competes with sugar for second place in the nation's earnings of Foreign exchange behind the bauxite/alumina industry which is the number one export. However, owing primarily to the continued depressed conditions in the world market price for sugar during 1977 , tourism was able to maintain its 1976 number two position ${ }^{1}$ despite a steady decline in hotel occupancy rates between 1970-1977 and reduced arrivals in Jamaica for the years 1976 and 1977 . Visitors expenditures is a product of the number of visitors (NV) times average duration of stay (ADS) times average expenditure per day (AED). Much of the increase in tourist expenditure can be attributed to increased inflation.

Tourism, however, due to its position relative to other sectors of the Jamaican economy is an important economic activity. In 1977 there were on $1 y 386,500$ visitors and the estimated gross earnings from tourism for the same year was $3 \$ 95.5$ million. ${ }^{2}$

${ }^{1}$ Economic and Social Survey, Jamaica 1977 prepared by the National Planning Agency, p. 169.

${ }^{2}$ Bank of Jamaica, Quarterly Bulletin, March, 1978. 
Total domestic export earnings for 1977 was recorded at $J \$ 707.3$ million, ${ }^{1}$ that is tourism contributed only about $13.5 \%$ of domestic export earnings and approximately $5 \%$ of gross domestic production at constant prices.

Tourism is not an end in itself, but merely a means of attaining a level of economic growth similar to today's standards and requirements for countries lacking other resources, or as an impetus for the development of other industries.

The economic contributions of tourism is difficult to analyze and measure. Some costs and benefits can be measured qualitatively. Strict balancing of costs and benefits are difficult to measure as often the data does not exist or is incorrect. Most involve trade-offs.

Chapter I, discusses tourism and the historical demand for travel, the trends in International Tourism worldwide and for developing countries, defines who is a tourist, tourist expenditures, origins, motivations and needs. Chapter II zeroes in on tourism in the Caribbean and Jamaica and the factors determining demand for tourism in the region and assesses how wel1 Jamaica compares with other Caribbean areas that have made tourism the main thrust of their economic development in terms of local environment and climate, level of infrastructure and physical limitations. Chapters III and IV form the core of this report. Chapter III presents tourism's performance and those of the other sectors or contributors to the Jamaican economy-mining, agriculture, Iight

${ }^{1}$ Bank of Jamaica, March 1979. 
manufacturing industries in achieving national development and the objectives as defined in the 5 year Development Plan 197882.

Chapter IV examines the diverse impact of tourism in Jamaica, the way in which the industry is structured and the social, cultural, economic, political and environmental effects. The non-pecuniary impacts such as the dangers of overcommercialization of original hospitality, problems related to high tourist densities, dependence and demonstration effects in a post colonial society are also explored.

Chapter $\mathrm{V}$ considers possible alternative strategies and makes recommendations.

The data for this paper comes mainly from secondary sources, Iiterature already existing in the social sciences and the hospitality industry specialized publications. Primary data comes from Government Publications, Tourists Boards and International Organizations. 


\section{TOURISM AND THE DEMAND FOR TRAVEL}

This chapter lays the foundation for what will follow in the successive chapters. It gives a brief history of travel, trends in International Tourism arrivals and expenditures worldwide and for less developed countries. It also defines who a tourist is and considers their needs, motivations and origins.

\section{A Brief History of Tourism}

Mass trave 1 as it exists today in the 20 th century using jet airplanes and automobiles has been the outgrowth of years of development.

The Romans were probably the first pleasure travellers although it is believed that in China and Japan pleasure travel existed by the time of the birth of christ. The ancient Romans both the rich and government officials could travel throughout the empire on good roads as much as a hunàred or more miles per day by using relays of horses furnished from rest post five or six miles apart. Romans traveled to Egypt and Greece to baths, shrines and seaside resorts, to theatrical productions, festivals athletic competition and then amusements. They were interested in history and religion seeing the Greek temples and the pyramids and monuments of Egypt.

"Those who could afford to travel before the time of Christ had the Seven wonders of the ancient world to see. A Greek guidebook from before the 
time of Christ listed them as: The Great Pyramid of Khufu, the largest of the Pharash's tombs in Egypt, built about 2600 B.C.: the Hanging Gardens at Babylon, built about the same time for his bride by King Nebuchadnezzar; the statue of Zeus at olympis, a 40-foot statue of the King of Gods on the site of the original games in Greece; the temple of Artemis at Ephesus on the coast of what is now Turkey; the Mausoleum at Halicarnassus from which we get the word mausoleum today; the Collosus at Rhodes built in $280 \mathrm{~B}$.C. at the harbour entrance of that island city in the Aegean Sea, and a lighthouse outside of Alexandris known as the Pharos, built about 240 B.C.1

With the collapse of the Roman empire in the fifth century, travel declined to almost a standstill as barbarians roamed Europe making travel indeed precarious. In the medieval period most of society was immobile, bound to the land, ekeing out an existence from the soil and travel for pleasure was unheard of for most.

Travel for religion existed in the form of pilgrimages to the Holy Land for Christians, Mecca for Moslem's and others to various shrines. Chaucer's Canterbury Tales are about travel to the Cathedral of Cantertury in the 14th century. With the Renaissance came increased travel both in Europe and via navigations the discoveries of the world beyond. The origin of the Grand Tour, in the 16 th century was the beginning of travel for education and the first example of the pleasure - motivated international travel of the modern era. ${ }^{2}$ The young aristocracy, children of British nobility plied the European continent to round out their

IDonald E. Lundberg, The Tourist Business (Boston, Cahners Books International, 1976$)$ p. 5

${ }^{2}$ Christopher Hubbert, The Grand Tour, New York: G.P. Putnam's Sons, 1969). 
education, socially and educationally, the itinerary included Paris (or elsewhere in France) Genoa, Milan, Florence, Rome, Venice, Switzerland, Germany and the low countries; lasting sometimes up to three years. The French revolution and Napoleonic wars ended the Grand Tour.

Next came travel for health. 17 th century physicians recommended those with bona fide illness to the medicinal waters of the spas. The word spa is taken from the town of Spa, Belgium which in turn is from the Wallon word espa, or fountain. 1

The Belgian resorts date to the early 14 th century although warm springs were used in early Greek and Roman times. Though the exact curative properties were unknown, "taking the waters" was expected to cure gout, dropsy, stomach maladies, even infertility and hysteria. ${ }^{2}$ Spas included both curative aspects as we11 as social events such as games, dancing anả gambling. 3

Sea bathing became popular by the $1730^{\prime} \mathrm{s}$. Some believed that salt water was even more beneficial than inland spas, so developed Brighton, the most popular, also Margate Ramsgate, Blackpool and Scarborough in Britian.

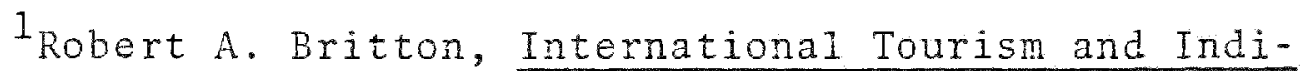
genous Development Objectives: A Study with Special Reference to the West Indies (University of Minnesota Ph.D 1978) p. 69

${ }^{2} \mathrm{H}$. Robinson, A Geography of Tourism, (London: MacDonald and Evans, 1976), p. 12.

${ }^{3}$ Robert $W$. McIntosh, Tourism: Principles, Practices, Philosophies, (Ohio: Grid Inc., 1977) p. 6. 
The masses of the people made one day excursion trips to the seaside and back. Patronage of seaside hotels modeled after the spas was limited to the elite.

It was the railway which really democratized travel. Passengers were first carried by rail in 1830. The newly completed railway between Liverpool and Manchester featured. special provisions for carrying passengers in addition to freight. The railway directors never anticipated there could be such a great demand for passenger travel. The typical charge was only 1 penny per mile, much lower than stagecoach fares and encouraged the pleasure-travel boom. Prior to this period travel was the exclusive preserve of the elite, the nomad, the merchants or people of the arts - actors, musicians, poets, philosophers, athletes. Soon, day excursions became a middle class activity as the working class neither had the money for such pursuit or the free time available. By the 1970's the proletariat began to patronized the seaside areas, the wealthier aristocracy moved further inland to South France, Swiss Alps and via steamship to various parts of the British Empire and America.

The birth of organized mass tourism is said to be biblical. In 1341, a book salesman, Baptist Preacher and Tract distributor of Derbyshire was on his way to a temperance meeting in Leicester when he conceived of the idea of runing a special train to carry friends of temperance from Leicester to Loughborough and back to attend quarter $1 y$ delegate meetings. The man was Thomas Cook and on the 5 th of 
July 1841, the train he ordered carried 570 passengers on this trip and back. The price was one shilling per passenger. It is arguable that Cook's real beginning as a "Mass excursionist" was the Liverpool - Caernarvan trip of 1845. The tourists travelled by rail to Liverpool from where they took a steamer to Caernarvan. The advertisement for the trip is said to have caused a sensation and the response was so overwhelming that a second trip had to be arranged. ${ }^{1}$ $\mathrm{Mr}$. Cook's company grew rapidly providing excursion tours to the continent and later to the United States and various British colonies. The company bearing his name is still one of the world's largest travel organizations.

Tourism in America was also aided by the railways. Early travel was on foot or horseback or small boats on rivers and lakes throughout the interior of the country. Most travel was from east to west. As roads were built stagecoach travel increased and "ordinaries" (small hotels) were built to cater to the travel-weary. Then came the railway and the inauguration of the Pullman Palace Sleeping car in the 19th century, which reduced the inconvenience of long distance travel for those who could afford it. ${ }^{2}$

Early 20 th century saw the development of tourism in the tropical regions of the world starting first with the French Riviera. The mediterrean sun was no longer shunned

${ }^{1}$ Louis Turner and John Ash, The Golden Hordes, International Tourism and the pleasure periphery, (Loncon:

Constable and Company Limited 1975) p. 51

${ }^{2}$ W.F. Rae, Westward by Rail, (New York: Appleton 1871) 
as the region became the in-place to be for the wealthy Americans, the international artistic and the literary elite. The wealthy Americans fleeing the protestant work ethic and a resurgence of puritan ways found the simple life agreeable. Sun tanning was IN. The deliberate darkening of the skin by exposure to the sun was previously abhorred by the leisured class prior to $1920^{\prime} \mathrm{s}$ when this same class of people had cultivated their 'milk and roses' with extreme care. Any deliberate tanning action savoured of identification with the lower and largely rural class and colored subject people. For the ladies, a pale complexion was a symbol of superior delicacy and even seclusion. ${ }^{1}$

The suntan became an essential picturesque element in the pursuit of 'expensive simplicity'. It was now sought after for precisely the reasons it had been avoided. It was associated with the simple virtues and closeness-to-the-soil of the peasant, and it was associated with what a liberal intelligensia conceived to be the superior spontaneity and natural sexuality of blacks. 2

The automobile age came in 1920. Construction of roads and highways has culminated in the 41,000 -mile network of the national system of Interstate highways. This system will link all cities of 50,000 or more and should be completed by 1980.3 The U.S. has in excess of 100 million autos registered and the number is growing.

\footnotetext{
${ }^{1}$ Louis Turner and John Ash, op.cit., p. 79. 2 Ibid. 3 Robert MeIntosh, op.cit., p. 8.
} 
Lastly came the commerical airplane which came into its own in the $1950^{\prime} \mathrm{s}$. In the United States $85 \%$ of travel in 1972 was by the automobile and $12 \%$ of total travel was by airplane. Buses declined to $2 \%$ and $.5 \%$ used trains for long distance travel.

Trends In International Tourism

Travel is not a new phenomeon to mankind but to the extent that it exists today as a large scale 20 th century commercial activity it has indeed surpassed itself. The past two decades have been the years of the most rapid growth in International Tourism. International Tourism as a "invisible" export plays an increasingly important role in International Trade.

During the years 1950-1972, prior to the oil crisis, the value of world trade increased at an annual rate of 9.0 percent whereas world receipts from tourism recorded annual rates of 11.7 percent. ${ }^{1}$ With the oil crisis in 1973-1974 the price of oil quadrupled and world trade showed a more rapid increase. Tourism receipts as a proportion of total world exports increased from 3.4 percent in 1950 to 5.8 percent in 1972 and dropped back to 3.4 percent in $1974 .^{2}$

World Tourism Organization (WTO) provisionally announced that in 1977 there were 245 million international tourist

${ }^{1}$. Burger, The Economic Impact of Tourism in Nepal, an input-output analysis, (Cornel1 University, Ph.D 1978)

${ }^{2}$ Ibid, p. 1 
Arrivals in the world; $12 \%$ more than in 1976. Total international tourist receipts during the same year came to over U.S. \$50,000 million, an increase of $15 \% .^{1}$ In 1976 there were approximately 220 million tourist arrivals around the world. that is one arrival for every twenty people. ${ }^{2}$ In 1976, receipts from International tourists were U.S. $\$ 40$ billion, with inflation being one of the major contributors to the increase.

IUOTO's study on long term forecasts expects international tourism will reach between 250 and 280 million arrivals by 1980 out of a global tourist movement of between 780 to 1050 million arrivals throughout the world. This means that although tourist movement since 1950 has been remarkable, the pace of growth may be yet greater in the future due to many social, technological, cultural and economic reasons. ${ }^{3}$ International Tourism is maturing and is no longer an elite activity but a mass production industry. This is indeed big business.

Worldwide International travel has grown from 25 million tourist arrivals in 1950 to over 245 million arrivals in 1977. The rise in tourism derives from several factors, the most important being improved technology, greater dis-

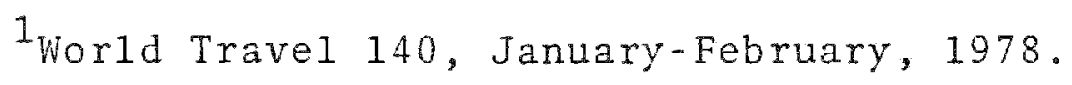

${ }^{2}$ ASTA Travel News, Trave1 $177 / 78$ : The Big Picture (New York: ASTA Travel News 1977), p.5

${ }^{3}$ Salah Wabab, Tourism Management, Press (London: Tourism International Press, 1975) p.18 
posable income, increased discretionary time, reduced cost of travel, higher educational levels and changing lifestyles. 


\section{TABLE I-1}

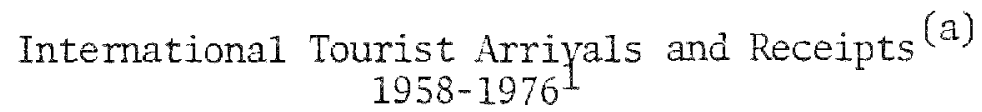

Tourist arrivals $\%$ change fror

Year

1958

1959

1960

1961

1962

1963

1964

1965

1966

1967

1968

1969

1970

1971

1972

1973

1974

1975

1976

1977 in millions previous year

55.3

63.0

71.2

75.3

81.4

92.8

106.4

117.8

128.2

138.0

141.6

154.0

168.4

181.5

198.0

215.0

209.2

213.0

220.0

$245.0^{*}$
Foreign exchange receipts in billion U.S. dollar

5.4

5.8

6.8

7.3

7.8

8.3

9.6

11.0

12.5

13.4

13.8

15.4

17.9

20.9

24.2

28.0

29.0

32.0

40.0

50.0
$:$ change from previous year

7.3

17.0

7.4

6.8

6.4

15.7

14.6

13.6

7.2

3.0

11.6

16.2

16.8

15.8

14.3

5.0

10.0

25.0

25.0

* Provisional figures by wTO

(a) Excluding payments for international transport

${ }^{1}$ Salah Wabab, op.cit, p. 18. 
Despite worldwide recession in 1973-74, international tourism held up very wel1. By 1975 global international arrivals totaled 213 million, within 1 percent of the 215 million arrivals in the pre-recession year 1973. At the same time domestic tourism in most countries was on the rise. ${ }^{1}$ One thing became apparent, that is despite recession, inflation and political turmoils, the consuming public continued to give priority to vacation travel, putting it ahead of the purchase of high priced material articles ${ }^{2}$ such as automobiles, household appliances and other high priced items. In fact, recession did not damage world tourism, it only changed it. People merely took vacations closer to home, chose less expensive accommodations and ate in more modest priced restaurants and did less long-haul foreign travel. International tourist arrivals increased 2 percent in 1975, world air traffic increased 3 percent, domestic auto travel in Europe and U.S. outpaced international trave1. 3 Tourism is a major growth industry, however, with the present fuel crisis pending one can predict a shift for the future to destinations closer to each tourist-generating country.

${ }^{1}$ ASTA Travel News, Travel '76', The Big Picture, p.2. 2 Ibid, p.2.

3 Ibid, p. 3 . 
TABLE $\quad$ - 2

EFFECT OF TWO YEAR RECESSION ON WORLD TOURISM

International Tourist Arrivals

(millions)

\begin{tabular}{|c|c|c|c|c|}
\hline Region & 1973 & 1974 & 1975 & $\begin{array}{l}\% \text { change } \\
1973-1975\end{array}$ \\
\hline Africa & 2.9 & 3.0 & 3.5 & 20.6 \\
\hline The Americas & 44.6 & 46.0 & 47.0 & 5.3 \\
\hline Europe & 157.0 & 149.0 & 151.5 & $3.5)$ \\
\hline Middle East & 3.8 & 4.0 & 3.0 & $21.0)$ \\
\hline Pacific and East Asia & 5.6 & 5.85 & 6.5 & 16.0 \\
\hline South Asia & 1.1 & 1.15 & 1.5 & 36.0 \\
\hline TOTAL & 215.0 & 209.0 & 213.0 & $0.9)$ \\
\hline
\end{tabular}

International Tourist Receipts (millions of U.S. dollars)

Africa

The Americas

Europe

Middle East

Pacific and East Asia

South Asia

TOTAL

$\begin{array}{rrrr}2,300 & 2,500 & 3,000 & 30.4 \\ 5,100 & 5,500 & 6,400 & 25.5 \\ 16,200 & 16,800 & 17,600 & 8.6 \\ 400 & 460 & 420 & 5.0 \\ 3,400 & 3,500 & 4,200 & 23.5 \\ 210 & 240 & 280 & 33.3 \\ 27,610 & 29,000 & 31,900 & 15.5\end{array}$

Source: World Tourism Organization (Provisional)

Recent years reveal five critical factors causing major shifts in the distribution of World Tourist traffic. These are:

1. Floating currency values which change the relative positions of various countries based on the cost of services purchased by the traveller.

2. Different rates of inflation that exaggerates cost differences between countries.

3. Higher airline fares due to increased gasoline costs.

4. Political disturbances that produced unfavorable press reports in important market areas.

5. Economic recessions occuring simultaneously in North America, Europe, and Japan. 


\section{TABLE I- 3}

INTERNATIONAL TOURIST ARRTVALS 1950, 1960 and 1970 BY REGIONS

\begin{tabular}{|c|c|c|c|c|}
\hline Region & 1950 & 1960 & 1970 & 1974 \\
\hline Africa & 523,480 & $1,137,624$ & $2,275,000$ & $3,000,000$ \\
\hline $\begin{array}{l}\text { Americas (North and } \\
\text { Latin America and } \\
\text { Caribbean }\end{array}$ & $7,484,660$ & $17,903,235$ & $32,400,000$ & $46,000,000$ \\
\hline Europe & $16,839,400$ & $50,351,156$ & $126,235,000$ & $149,000,000$ \\
\hline Middle East & 196,620 & 883,024 & $2,815,000$ & $4,000,000$ \\
\hline $\begin{array}{l}\text { Pacific and East } \\
\text { Asia* }\end{array}$ & 237,250 & 863,635 & $4,435,000$ & $6,000,000$ \\
\hline South Asia* & & & 850,000 & $1,000,000$ \\
\hline
\end{tabular}

*These regions are newly reorganized by IUOTO under two regional comittees; previously being one region, namely, Asia/Australia.

Source: IUOTO

It is estimated that 15 countries of the 148 independent nations in the World receive approximately 90 percent of the world's foreign tourist arrivals. These are in descending order the United States, Spain, France, Italy, Mexico, Austria, Federal Republic of Germany, United Kingdom, Canada, Switzerland, Netherlands, Yugoslavia, Belgium, Denmark, Greece and Portugal. ${ }^{1}$

In 1975,85 percent of the foreign travellers emanate from approximately one dozen countries such as the United States Federal Republic of Germany, France, Canada, United Kingdom, Japan, Italy, Netherlands, Belgium, Austria, Sweden and Switzer1and. The United States and Germany accounted for about 48

${ }^{1}$ Somerset Waters and William D. Patterson, "World Tourism Perspective" CTA: Domestic and International Tourism (Wellesley Institute of Certified Travel Agents, 1977) p. 38. 
percent of the total world international tourist expenditured in 1975 (excluding transportation). ${ }^{1}$

The largest source of International travellers, the United States spent about $\$ 70$ billion for domestic and foreign travel. Foreign travel accounted for about $\$ 9.5$ billion or 13.5 percent of the total. ${ }^{2}$ This shows that considering the large size and weath of the United States, Americans do not spend heavily for foreign travel.

Expenditures by Germans come to about 114,000 per thousand population; for Canada the figure is $\$ 70,000$ and for the U.S. only $\$ 28,000$ (1974 expenditures). 3

The international tourist constitutes only a small percentage of the worlds 4 billion population. The overseas travellers from the United States which is the largest tourist - generating economy constitutes less than three percent of the population in 1970 .

As George Newman of Pan American World Airways said in his definition of the potential foreign travel market "... subtract 30 percent for the very old, the very young, the sick and the poor who will always be with us. Another 15 percent might be classified as 'hard core non-travellers' leaving 55 percent." 4

$1_{\text {Ibid. }}$

${ }^{2}$ Somerset Waters and William D. Patterson, op.cit. p. 38. 3 Ibid.

${ }^{4}$ Donald Lundberg, The Tourist Business, p. 8. 
A 1971 study found that 35 percent of all U.S. consumers (about 48 million people) said they had never used air travel. Of those who had not flown 30 percent said they had no reason to fly, and 21 percent said they were afraid to fly. About 13 million persons, according to the survey said they could not afford to do so. 1

Holidays are products of advanced customer societies which can only survive by finding fresh incentives to motivate the labor force into further bursts of production. ${ }^{2}$ Although people want more leisure they work harder than they ideally want to just so they can save the money necessary to allow them to spend their leisure time in the style they choose. Thus, by making leisure relatively expensive, the tourist industry helps to keep the industrial machinery of these developed country's well oiled and running smoothly.

Per capita income of a country correlates closely with the amount of travel engaged in by its citizens both domestic and International. U.S. citizens comprise about 6 percent of the world's total population yet account for one third of all domestic and international trave1. 3

One can, therefore, take a look at the growth in disposable income for the U.S.

$1_{\text {Albert E. Sindlinger, Sindlinger's Air Travel Demand }}$ Study (presentation for the Eastern Council for Travel Research, Dec. 7, 1971).

${ }^{2}$ Louis Turner and John Ash, op.cit., p. 181.

${ }^{3}$ Donald Lundberg, op.cit. p. 10. 
TABLE I - 4

GROWTH IN U.S. PER CAPITA DISPOSABLE PERSONAL INCOME, 1950-1975

Type of Measure

Current Dollars

1972 Constant Dollars

$$
1950
$$

1955

1960

$\$ 1355 \$ 1654$

2386 2577
$\$ 1934$

2698

\section{5}

1970

1975

Source: U.S. Bureau of the Census, Statistical Abstract of the Inited States: 1976,97 th edition, p. 396.

Issuance and renewal of U.S. passports is a indicator of the desire for international travel as seen in Table $I-5$

\section{TABLE I-5}

\begin{tabular}{|c|c|c|c|}
\hline Year & Number & Year & Number \\
\hline 1960 & 853,087 & 1969 & $1,820,192$ \\
\hline 1961 & 857,961 & 1970 & $2,219,159$ \\
\hline 1962 & 906,900 & 1971 & $2,398,068$ \\
\hline 1963 & $1,055,504$ & 1972 & $2,728,021$ \\
\hline 1964 & $1,133,228$ & 1973 & $2,729,104$ \\
\hline 1965 & $1,330,290$ & 1974 & $2,415,003$ \\
\hline 1966 & $1,547,725$ & 1975 & $2,334,359$ \\
\hline 1967 & $1,685,512$ & 1976 & $2,560,000$ \\
\hline 1968 & $1,748,416$ & 1977 & $2,800,000$ \\
\hline
\end{tabular}

Growth rates: $1950-1975=679$ percent

$$
\begin{aligned}
& 1960-1975=174 \text { percent } \\
& 1965-1975=75 \text { percent }
\end{aligned}
$$

Source: Passport Office, U.S. Department of State, Summary of Passport Statistics, January 1976, p. 18. 
TABLE I- 6

DEPARTURE OF U.S. CITIZENS BY AIR TO SELECTED AREAS $1961-1975$

\begin{tabular}{lrrrr} 
Year & Caribbean & Eurode & Asia & Mexico \\
\hline 1961 & 381,085 & 643,297 & 124,345 & 174,993 \\
1963 & 377,738 & 882,213 & 170,126 & 225,185 \\
1965 & 609,966 & $1,218,961$ & 252,094 & 288,940 \\
1967 & 904,165 & $1,632,447$ & 293,934 & 421,820 \\
1969 & $1,285,135$ & $2,227,099$ & 367,375 & 534,671 \\
1971 & $1,326,034$ & $3,047,944$ & 518,788 & 656,725 \\
1973 & $1,530,847$ & $3,755,395$ & 596,800 & 983,976 \\
1975 & $1,426,949$ & $3,092,838$ & 621,837 & 966,231
\end{tabular}

Source: Immigration and Naturalization Services, U.S. Department of Justice Reports of Passenger Travel Between the United States and Foreign Countries, annually, 1961-1976.

In addition, due to the size of the American Market, U.S. aircrafts account for approximately $40 \%$ of all world air travel measured in revenue passenger miles. 1

${ }^{1}$ Somerset Waters and William patterson, op.cit. p.38 
TABLE I-7

WORLD AIRLINE STATISTICS

Includes scheduled carriers throught the world but does not include supplemental carriers

\begin{tabular}{|c|c|c|c|c|}
\hline & $\begin{array}{l}\text { Passengers } \\
\text { (millions) }\end{array}$ & $\begin{array}{l}\text { Percent } \\
\text { Increase } \\
\end{array}$ & $\begin{array}{c}\text { Passenger Miles } \\
\text { (millions) }\end{array}$ & $\begin{array}{l}\text { Percent } \\
\text { Increase }\end{array}$ \\
\hline 1965 & 177 & 14 & 123,000 & 16 \\
\hline 1966 & 200 & 13 & 142,000 & 16 \\
\hline 1967 & 233 & 17 & 169,500 & 19 \\
\hline 1968 & 262 & 12 & 192,500 & 14 \\
\hline 1969 & 293 & 12 & 218,000 & 13 \\
\hline 1970 & 314 & 7 & 239,000 & 9 \\
\hline 1971 & 329 & 5 & 252,000 & 5 \\
\hline 1972 & 361 & 10 & 287,000 & 14 \\
\hline 1973 & 404 & 12 & 323,000 & 12 \\
\hline 1974 & 423 & 5 & 339,000 & 5 \\
\hline 1975 & 433 & 2 & 348,000 & 3 \\
\hline \multicolumn{5}{|c|}{ WITH USSR INCLUDED } \\
\hline 1970 & 383 & -- & 287,000 & $\cdots$ \\
\hline 1971 & 407 & 6 & 308,000 & 7 \\
\hline 1972 & 443 & 9 & 345,000 & 12 \\
\hline 1973 & 489 & 10 & 384,000 & 11 \\
\hline 1974 & 514 & 5 & 406,000 & 6 \\
\hline 1975 & 529 & 3 & 420,000 & 3 \\
\hline
\end{tabular}

Source: ICAO 
The years 1950-1960 called 'The Golden Age' of tourism saw destinations closest to the tourist generating economies growning most such as Spain, Italy, Caribbean and Hawaii. Today the developing countries have slowly increased their share of world tourism receipts to around 20 percent of the total. However, 45 percent of this is accounted for by two countries: Mexico and Yugoslavia.

The figures given in Table I - 8 are for developing countries reporting to IUOTO. Although the statistics for receipts and arrivals in developing countries are incomplete and their coverage and composition may have changed, the figures are an indication of a trend in the International Tourism Industry in developing countries.

\section{TABLE I-8}

THE GROWTH OF INTERNATIONAL TOURISM IN THE DEVELOPING COUNTRIES 1962-1973

Tourist Arrivals

\begin{tabular}{|c|c|c|c|}
\hline Years & Numbers $(000)$ & Annual growth (\%) & of world total \\
\hline 1962 & 5,973 & $\ldots$ & 7,3 \\
\hline 1968 & 10,300 & - & 7.4 \\
\hline 1969 & 13,374 & 29.8 & 8.7 \\
\hline 1970 & 16,151 & 20.8 & 9.6 \\
\hline 1971 & 20,100 & 24.4 & 11.1 \\
\hline 1972 & 26,655 & 32.6 & 13.5 \\
\hline 1973 & 29,400 & 10.3 & 13.7 \\
\hline
\end{tabular}

Tourist Receipts

\begin{tabular}{lccc}
\hline Years & Amount (\$N) & Annual growth $(\%)$ & of world trade \\
\hline 1962 & 1,468 & -- & 18.8 \\
1968 & 2,348 & - & 17.0 \\
1969 & 2,539 & 8.1 & 16.5 \\
1970 & 3,389 & 33.5 & 18.9 \\
1971 & 3,865 & 14.0 & 18.5 \\
1972 & 4,909 & 27.0 & 20.3 \\
1973 & 5,737 & 16.9 & 20.8 \\
\hline
\end{tabular}


While total international tourist movements increased by 164 percent over the period $1962-1973$ and receipts rose by 254 percent, the increases for developing countries during this same period were 392 percent for arrivals and 291 for receipts. ${ }^{1}$ The trend is for an increase in the percentage of arrivals in developing countries.

\section{TABLE I-9}

THE SHARE OF DEVELOPING COUNTRIES IN WORLD TRADE AND IN INTERNATIONAL TOURISM $1962-1973$

Share of World Trade Share of Intemational Tourism Recei

\begin{tabular}{lcccc}
\cline { 2 - 5 } Years & Value $(\$ \mathrm{NW})$ & Share $(\%)$ & Value $(\$ N)$ & Share \\
\hline 1962 & 29,100 & 20.5 & 1,468 & 18.8 \\
1968 & 44,350 & 18.5 & 2,348 & 17.0 \\
1969 & 49,520 & 18.1 & 2,539 & 16.5 \\
1970 & 55,450 & 17.8 & 3,389 & 18.9 \\
1971 & 63,010 & 18.0 & 3,865 & 18.5 \\
1972 & 74,650 & 18.0 & 4,909 & 20.3 \\
1973 & 102,500 & 18.1 & 5,737 & 20.3
\end{tabular}

Sources: GATT: International Trade IUOTO

International tourism weathered the economic recession of 1974 much better than expected. In 1974 tourist arrivals reached $\$ 209$ million, a drop of less than 3 percent from the 215 million arrivals of 1973. With the exception of Europe where there was a fall off in the long-haul travel from North America, other regions showed increases in international tourist arrivals. The years since 1974 shows tourism rapid growth recovery to 245 million arrivals and expenditure of

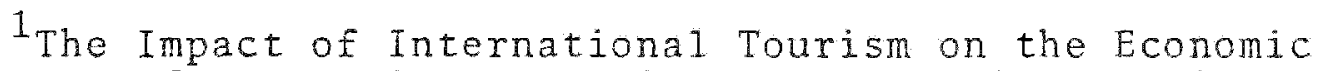
Development of Developing Countries - International Union of Official Travel Organizations, p. 3. 
U.S. $\$ 50$ billion in 1977. Developing countries will continue to play an increasingly significant role in International Tourism and larger roles in the individual economies.

International travel is dependent on and will continue to depend on disposable incomes, shorter work week and increased leisure time, increases educational levels, reduced value placed on material possessions, changing lifestyles and greater mobility. Population growth is not a significant contributor as out of the total world population of 4 bilition only a small percentage will cross international borders.

Who is a Tourist?

According to the International Union of Trave1 Organizations (now the World Tourism Organization, WTO) "The term "visitor' describes any person visiting a country other than that in which he has his usual place of residence, for any reason other than following an occupation which is renumerated from within the country itself."

This definition covers two categories:

A. Leisure (recreation, holiday, health, study, reIigion and sport), and

B. Business, family, mission, meetings.

Travellers staying for less than twenty-four hours are classified under "excursionists".

Tourist themselves are not a homogenous group each is an individual with separate needs, motives and attitudes. Travel today, to a large extent is a reflection of age bracket, disposable income, occupation, educational level, social status, race, place of residence and life style. 
The younger generation tend to travel somewhat more than elders for example half of the population in the U.S. (approximately 107 milion) is under age 27. People in their early 20's tend to be more adventureous and therefore more willing to travel. With increasing age, over 60 years the individual becomes more passive. People in managerial and professional jobs tend to be more mobile internationally so do people who receive long paid holiday benefits. The key factor seem to be income. Obviously there is a minimum income below which any form of holiday is totally out of the question. In the U.S.A., this minimum would be around $\$ 10,000$.

Motives for Trave1

It is possible for as many motives for leisure travel as there are individuals traveling. In general, the majority of reasons seem to belong at the very top levels of Maslow's pyramidal chart, in the region of self-actualization and gratification.

Todays lifestyle in the late 20 th century favors increased travel. The decreased work week, 3 day holiday weekends, higher education, improved transportations and communications, and stable if not actually decreasing travel fares. There is also increased awareness of other countries, places and cultures, a larger percentage of populations living in urban centers in developed, greater affluence, smaller Eamilies, early retirement increase in longevity and improved government securtiy programs are all forces which increase people propensity to travel. 
Generally there are more than one factor combined which explains why a person chooses a trip. The majority of the reasons, however, are physical, cultural sociological or status-prestige related.

Physical motives relate to the desire for rest, relaxation, recreation for reasons including health. Cultural is the desire to learn more about the world, to leave the things one is familiar with and get acquainted with other cultures, lifestyles, see ancient monuments. Sociological could involve travel just for the sake of overcoming boredom and monotony of economically developed countries where the daily pressure of working and living in highly urbanized centers are heightened or to visit friends and relatives. The escape motive has been fully explored, that is the need to escape repetitive, unchallenging work and boring homelife to a place where one can for a short while make believe the good life of the privileged few. Status-prestige involves keeping up with the Joneses and 'one upmanship'.

Travel for several years has been 'chic' and a way' of impressing others. From the very early 20 th century

"a deep sun tan was the visible proof that the bourgeois had the money and leisure to escape from the northwest European metropolis to the south and the sun of the Mediterrean. For a suntan always provokes the question 'where have you been this year?" "1

John A. Thomas 1 isted 18 motivations he believes to be important causes of people traveling in ASTA Travel News, August 1964 .

${ }^{1}$ Louis Turner and John Ash, op.cit., p. 80 , 
1. To see how people in other countries live, work and play

2. To see particular sights

3. To gain a better understanding of what goes on in the news

4. To attend special events

Relaxation and Pleasure

5. To get away from everyday routine

6. To have a good time

7. To achieve some sort of sexual or romantic experience

Ethnic

8. To visit places your family came from

9. To visit places your family, or friends have gone to

Other

10. Weather (for instance to avoid winter)

11. Hea1th (sun, dry climate and so on)

12. Sports (to swim, ski, fish or sail)

13. Economy (inexpensive living)

14. Adventure (new areas, people, experience)

15. One-upmanship

16. Conformity (keeping up with the Joneses)

17. To participate in history (ancient temples and ruins, current history)

18. Sociological motives (to get to know the world) 
Trave1 makes good conversations and so does home movies, souvenirs, T-shirts and frayed bagged tags deliberatly collected and revered.

H. Peter Gray provides an interesting distinction between two basic reasons for pleasure travel: "Wanderlust" and "Sunlust". He defines them as:

Wanderlust is that basic trait in human nature which causes some individuals to want to leave things with which they are familiar and to go and see at first hand different existing cultures and places, or the relics of past cultures in places famous for their historical associations, ruins, and monuments.... Wanderlust is a basic a human characteristic as curiosity....

Suniust generates a special type of travel which depends upon the existence elsewhere of different or better amenities for a specific purpose than are available locally....

The crucial differences between the two types of travel relate to the degree to which they are likely to be international (as opposed to domestic) and in the type of travel facilities required by the destination. Wanderlust may be expected to be much more largely international in character than sunlust travel.....

Most travellers, however, on their first few trips across international borders tend to seek the familiar, they seek a home away from home, close not only in distance but more importantly in culture and speech. They desire food and beverage they are accustomed to. As Robert McIntosh states:

"Often the modern tourist is not so much abandoning his accustomed environment for a new one as he is being transported to foreign soil in an 'environmental bubble' of his nature culture. To a certain extent he views the people, places and culture of that society through the protec- 
tive walls of his familiar 'environmental bubble', within which he functions and interacts in much the same way as he does in his own habitat. 1

As the traveller becomes more adventureous, the distances he will travel increase both physically and cultural$1 y \cdot$

In the fall of 1974 , a survey was done by Attitudes of U.S. travel agents. Travel agents were selected as the focus of the investigation because of their influence on the selection of their client's for vacation destinations. Forty percent of destination decisions made by individuals planning international trips through travel agents were made in the recommendation of their travel agent. U.S. travel agents play a strategic role in directing the flow of U.S. citizens travel to foreign countries. The agents were discovered to be primarily concerned with cleanliness, safety and reliability, the three factors very important to the potential traveler. Other factors considered were:

1. quality of the accommodation;

2. price-cost;

3. sightseeing opportunities;

4. reliability of hotel reservations;

5. interesting cities;

6. climate, beautiful scenery;

7. personal and property safety;

8. friendiness of locals;

9. reputed food and water contamination;

1Robert McIntosh, Tourism, Principles, Practices, Philosophies, op.cit., p. 49. 
10. cultural attractions;

11. popularity of destination;

12. resort-beach areas;

13. stability of government;

14. endemic diseases;

15. reliability of local transportation;

16. shopping, outstanding food;

17. distance to be traveled;

18. recreationa 1 facilities;

19. courtesy of customs officials;

20. language difficulties;

21. gambling facilities;

22. ethnic heritage;

23. spectator sporting events;

24. racial dissimilarity;

25. exit/airport taxes;

26. religious affiliations 1

The tourist has demonstrated to be overly concerned with convenient location, comfortable surroundings, pricevalue, reputation for good food and beverage, size of the room and security-safety from robbery and abuse. For pleasure trips, price-value ranks first, followed by recreation and size of the room. For business location plays the dominant role. ${ }^{2}$ The international tourist is preoccupied with his

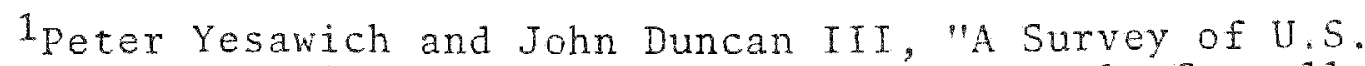
Travel Agents": Latin American and Caribbean Trave1, Corne11 Quarter1y, May 1975.

${ }^{2}$ Malcolm Noden, "Consumer Habits in the Hospitality 
own creature comforts in most cases the demand is for luxurious service and care, high quality of hotels and services of an international standard; drawn by an image created by advertisements and promotions by books and brochures aimed to stir the imagination and create certain expectations of vacation destinations relating to scenery, people and climate.

The pattern emerges for Americans. Usually they take their holidays primarily within the U.S. With some overflow into Mexico. However, once he decides to go overseas, in 1972 over $55 \%$ of the $\operatorname{cases}^{1}$ they make the transatlantic flight to Europe with the Caribbean and Central America a low second, under 30 percent. 


\section{CHAPTER II}

This chapter introduces the Caribbean economies and Jamaica. It assesses how well Jamaica compares with other Caribbean areas that have made tourism the main thrust of their economic development. It also seeks to analyze the factors determining demand for tourism in the region by Governments and by tourists themselves and discusses Caribbean Tourism An Introduction to the Structure of the Caribbean Economies: Location

For both climatic and geographic reasons the Caribbean is regarded as one. It is a tropical region lying between the Equator and the Tropic of Cancer. The Caribbean Islands stretch from the southeast of Florida to the northeast of South America, and are washed by the Caribbean Sea. They are said to be summits of sunken mountain chains and coral reefs. By definition, the Bahamas to the north of the region is not a part of the Caribbean but because their history and economy are similar they are treated as Caribbean. The Caribbean Sea is part of the Atlantic Ocean lying south of the Gulf of Mexico and bounded by the West Indies Islands. It is blown by the "Trade Winds" which in the days of sailing vessels enhanced trading in the area. It also serves the purpose of separating each island and adding to their insularity. The distances between them are far, however a close look will reveal numerous basic commonalities of problems and potentials. Except for Guyana, the territories are all small is 1 and economies. 
History

The Caribbean Islands were discovered by Columbus between the years 1492-1502 in the name of Spain. Spain was not able to hold onto them for long as soon they passed to other nations, France, Great Britain, Netherlands "according to the vieissitutes of war", 1

However before Colonisation, it is said the first people to populate parts of the West Indies were the Siboney Indians who migrated from Florida to the Bahamas, then to Cuba, Hispaniola and Jamaica. Little is known of them. About 1000 A.D. they were overwhelmed by Arawaks moving north, island by island, from the Guiana region of South America. The Arawaks were a peaceful people so assimilation of the Siboneys was probably achieved through intermarriage. ${ }^{2}$ The Arawaks were fleeing their warlike enemies, the Caribs. Their densest settlement was in Hispaniola where they practised primitive agriculture for subsistence. The Colonisers cultivated a variety of tropical crops, such as cotton, coffee, tobacco, bananas, cocoa, ginger and sugar - with emphasis on export. With the second half of the eighteen century sugar became the most important crop as there were markets in Europe and North America and the climate in the West Indies was very appropriate for its production. Colonial sugar was given the incentive of preferential tarriffs in

${ }^{1}$ Isedeo Jainarain, Trade and Underdevelopment, a study of the sma11 Caribbean Counties and Large Multinational Corporates (Guyana: Institute of Development Studies 1976) p.69.

${ }^{2}$ George Metcalf, "An Outline of West Indian History" Caribbean Yearbook $1978 / 79$, p. xxv 
Britain. The tariff structure however related only to raw sugar, and by 1805 Jamaica was the 1 argest sugar producer with 105,000 tons. At first the Indians were forcibly put to work, however before the end of the sixteenth century the Indians ceased to exist. Hard work and European diseases proved to be too much for them. With increased demand for Labor, slaves were imported from Africa. With emancipation in 1830, ex-s1aves left the estates and cultivated their own small holding or worked only part time or on a seasonal basis on the sugar estates. By the $1850^{\prime} \mathrm{s}$ many planters were bankrupt. The chief reasons were emancipation (1838); abolition of preferential duties on colonial sugar (1846-54); the high incidence of absentee landlordism; and the failure of landlords to improve their estates during good times. 1

In the 19 th century Indian immigrants arrived from India to ease the labor shortage and later Chinese, Lebanese and other Europeans. At the same time sugar from beets was on the increase. Whereas in 1955 sugar from beets accounted for only 10 per cent of world sugar, in 1875 its share was about 40 per cent. By 1899 this had increased to approximately two thirds. With the increase in beet sugar, the price of sugar fell from 520 per ton in 1875 to $E 10$ per ton in 1895. The West Indies sugar industry was threatened.

Since her discovery over 200 years before "Cuba had slept economically" ${ }^{2}$ Then in the 18 th century Cuba was producing the

${ }^{1}$ Iserdeo Jainarain, op. cit. p. 70.

${ }^{2}$ George Metcalf, op.cit., p. xxviii. 
best tobacco in the world and started to get into sugar production - slowly Cuba mechanized sugar production. Between 1801 and 1865, they imported over 600,000 slaves and pushed their way to the top of the sugar business. Cuba was now Spain's chief colony.

As the economic difficulties increased all British islands, except Bahamas, Barbados and Bermuda, by the 1880's gave up representative government and accepted direct rule from London. Martinique and Guadeloupe moved closer to France. The Colonial Governments encouraged diversification. Rice exports began in British Guiana and bananas introduced. Population was increasing at a rapid rate and the great depression saw the colonies in a bad state. The mother countries had their problems and were not of much help, with the world war on their hand. During the mid-thirties, there were riots in the British Caribbean and an abortive rebeliion in Puerto Rico. The riots in the British West Indies started the development of labor unions and the demands for independence. After 1948, these trends continued but West Indian Nationalism was hampered by the economic limitations of the individual countries. The British colonies sought to solve the problem for federation inaugurated in 1958 but this collapsed three years later. ${ }^{1}$

With the disintegration of Federation, Jamaica, Trinidad and Barbados became independent, in addition to British Guiana (now Guyana) who had never joined the Federation. The other 
British Colonies maintained their Iink with Great Britain. The French west Indies chose full union with France rather than Independence. In 1954 the Netherlands reformed into a tripartite state consisting of Holland, Surinam and Netherland Antilles. 1

In the revolution in Cuba in 1958 Fidel Castro overthrew the Batista Government. Today the West Indian Islands seek economic diversification and foreign investment and slowly Tourism, despite its unreliability has evolved to be one of the major industries in the region.

Population

The islands are al1 small and densely populated, for example, Barbados is only $166 \mathrm{sq}$. miles but it has a population density of 1,438 persons per sq. mile; Puerto Rico's total 1 and area is $3,435 \mathrm{sq}$. miles including the offshore island and has a density of 955 per sq. mile. Jamaica with a land area of $4,243.6 \mathrm{sq}$. miles showed an increase in density from 293 in 1943 to 410 per sq. mile in 1978. Trinidad and Tobago has 1880 square miles and 519 persons per sq. mile and Guyana has an overall density of 8.5 persons per sq. mile but on the coastal region where ninety percent of the population lived in 1970 , the density was over 120 per sq. mile. ${ }^{2}$

${ }^{1}$ George Metcalf, op.cit. p.xxviii.

${ }^{2}$ Five Year Development P1an, 1978-82 - Government of Jamaica. 
The net population growth rate for all the islands, except for Dominican Republic are modest at less than 2 percent per year. A high birthrate, over 3 percent of the population is offset by an even higher migration rate. The density for both Jamaica and Barbados would have been much higher but for emigration. Between 1948-1970 Jamaica and Guyana showed the highest rates of natural population increase, yet Jamaica"s population increase was lower than Guyana and Trinidad-Tobago. The explanation is the high emigration rate for Jamaica adults. Between 1950-1970 the natural increase totalled 976 thousand while net migration was about 321 thousand, that is 33 percent of the natural increase. 1

Table II-1

Natural Increase and Net Migration in the Commonwealth C.A. $1950-1970$

$\begin{array}{lccc} & \text { Natural Increase } & \text { Net Migration } & 2 \text { as } \% \text { of } 1 \\ & (000) & (000) & \\ \text { Jamaica } & 976 & 321 & 32.9 \\ \text { Trinidad \& Tobago } & 456 & 48 & 10.5 \\ \text { Guyana }^{*} & 208 & 37 & 17.9 \\ \text { Barbados } & 92 & 33 & 35.9\end{array}$

* 1960-1970 Sources: Jamaica - Statistical Abstract Trinidad \& Tobago - Annual

Statistical Abstract Guyana - Annual Statistical Abstract Barbados : Abstract of Statistics

${ }^{1}$ Iserdeo Jainarain, op. cit. p. 79. 
Migration also plays an important part in the economy of Puerto Rico as indicated in Table II-2.

Table II- 2

\begin{tabular}{lrrrr}
$\begin{array}{l}\text { Population } \\
\text { Total }\end{array}$ & 1970 & 1972 & 1974 & \multicolumn{1}{c}{1975} \\
$\begin{array}{l}\text { Births } \\
\text { Total }\end{array}$ & $2,712,000$ & $2,868,000$ & $3,031,000$ & $3,121,000$ \\
$\begin{array}{l}\text { per 1,000 } \\
\text { Deaths }\end{array}$ & 70,000 & 72,000 & 73,000 & 72,000 \\
$\quad$ Total & 25.8 & 25.1 & 24.0 & 23.0 \\
per 1,000 & 18,000 & 19,000 & 19,000 & 19,000 \\
Migration & 6.6 & 6.6 & 6.2 & 6.0 \\
Arrivals & $3,032,628$ & $2,347,483$ & $2,565,900$ & $2,399,533$ \\
Departure & $2,076,710$ & $2,306,399$ & $2,539,783$ & $2,359,959$ \\
Balance & $-44,082$ & $+41,084$ & $+36,117$ & $+39,574$
\end{tabular}

At the Census taken on April 1970, the total population was 2,712,033. Other figures are estimates, July 1 , based on natural increase and migration trends.

Source: Caribbean Yearbook 1978/79.

The St. Kitts group of islands officially lost $19 \%$ of their total population between 1961 - 1968, St. Vincent lost $13 \%$. One has to note also that in the estimates published for migration, there is a lot of migration which goes unrecorded, so the actual figures are much higher. ${ }^{1}$

\section{Effects of Migration}

Migration has played its part in reducing population - 1and pressures but there are various problems associated with it.

1. It leaves the population with a high proportion of very young and old, both of which require a high level of social services without being able to make a commensurate social contribution. ${ }^{2}$

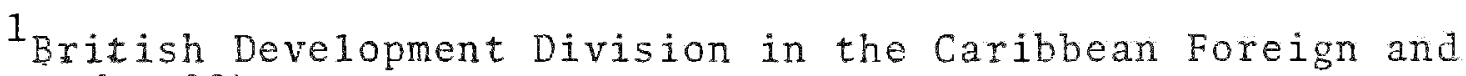
Commonwealth office, Overseas Development Administration, "Anguilla, A Report to Her Majesty's Commissioner," Dec. 1971, p. 6. 
2. It deprives the country of young leadership and an adequate return on the investment in the education of the person who later migrates.

3. The returning migrants, often they have developed values "antithetical" to the agricultural society they are to be in.

Political Situation

The Caribbean is a heterogeneous region. The area is divided into British Commonwealth territories, French, Dutch and Spanish territories. As a result four different major languages are spoken in the region, English, French, Dutch and Spanish The culture and basic political and economic structures differ according to each territories' past relationship with their particular colonial mother country. This helps to explain the absence of cohesion of these societies. The legacy of the past colonial regimes is fragmentation. A11 attempts at operating as a region has basically failed. The legacy of "divide-and-rule"l is today internalized by the small bureacracy in each island. Caribbean peoples are noted for their "non participation" in the political life of their country. Whereas this could have been understood in the colonial era, this should not be so today as a former Senator from Trinidad summarized it: "Democracy is carricatured by five minutes in a polling booth every five years." 2

1 Action for Community in the Caribbean, a Cadec Publication (Island Press, Barbados) p. 7.

2 Ibid. p. 8. 
Economic Situation

Kari Levitt and Lloyd Best aptly describe the "Character of Caribbean Economy", they state:

"Essential1y, the Caribbean economy has undergone little structural change in the four. hundred-odd years of its existence. By this we mean that the character of the economic process in the region seems not to have been significantly altered over the periods. Neither the modifications which, through time, have been made to the original institutions, nor the new institutions which have from time to time been incorporated into the economy, have relieved its dependence on external development initiatives. The economy remains, as it has always been, passive1y responsive to metropolitan demand and metropolitan investment. (1)

The following economic conditions still exist in the Caribbean:

1. "A high-cost export agricultural sector, highly dependent on preferential shelter in metropolitan markets.

2. External decision-making by large corporations, and a shortage of local entrepreneurship, local technological innovation and appropriate local institutions.

3. A relatively undiversified and unintegrated structure of production and very heavy dependence on exports and imports. The situation is made worse by the small size of the economies and the lack of regional integration.

${ }^{1}$ Kari Levitt and Lloyd Best, "Character of Caribbean Economy: Caribbean Economy: (Institute of Social and Economic Research edited by George L. Bechford), p. 37. 
4. A very undeveloped domestic agricultural sector producing food for local consumption.

5. Deep-seated and growing structual unemployment and under-employment.

6. Apart from the usual "class" inequalities growing unequalities as between the privileged workers in the modern sector on the one hand and the unemployed and persons in the rural sector on the other hand.

7. A pattern of consumer taste and aspiration heavily influenced by those in the developed metropolitan countries, and the persistent pressures of commercial advertisers through the media. ${ }^{1}$

The mainstay of the Caribbean economics are agriculture and Tourism. Cuba the largest island has had very little tourism from about 1959. Their most important product is sugar. The Dominican Repub1ic, the next largest, has a small tourist business and is dependent on sugar, like Cuba. Haiti has a small developing Tourist Industry but not much else, the majority of the people are at subsistence level. Puerto Rico has a small manufacturing industry, agriculture and Tourism. Jamaica in 1977 was the second largest producer of Bauxite behind Australia, in addition Jamaica

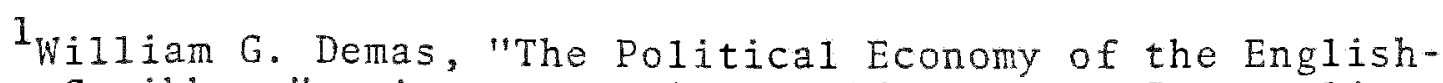
speaking Caribbean" - A summary view, Bridgetown, 1971, p. 14. (A very similar list has been prepared by Mr. John Mayers of the Institute of the Social and Economic Research of the University of the West Indies.) 
has bananas, sugar and tourism. Barbados and Antigua have sugar and Tourism. Trinidad has oil and agriculture and a small amount of Tourism. For the Bahamas, U. S. Virgin Islands, the Cayman Islands and Bonaire, tourism is the chief economic activity. The salt making islands of Curacao and Aruba have oil refining and Tourism. Bananas is the chief product of the Windward Is Iands.

Social Situation

The social situation of pre-colonial times still exist today. In most cases Independence has brought a reduction of the numbers of expatriates traded for local personnel and a changed relationship with the metropolitan countries. Often the United States is chosen over the United Kingdom and the currencies of the region tied closer to the United States dollar rather than the sterling pound. In addition there is an emerging national pride and development of a midale class. 


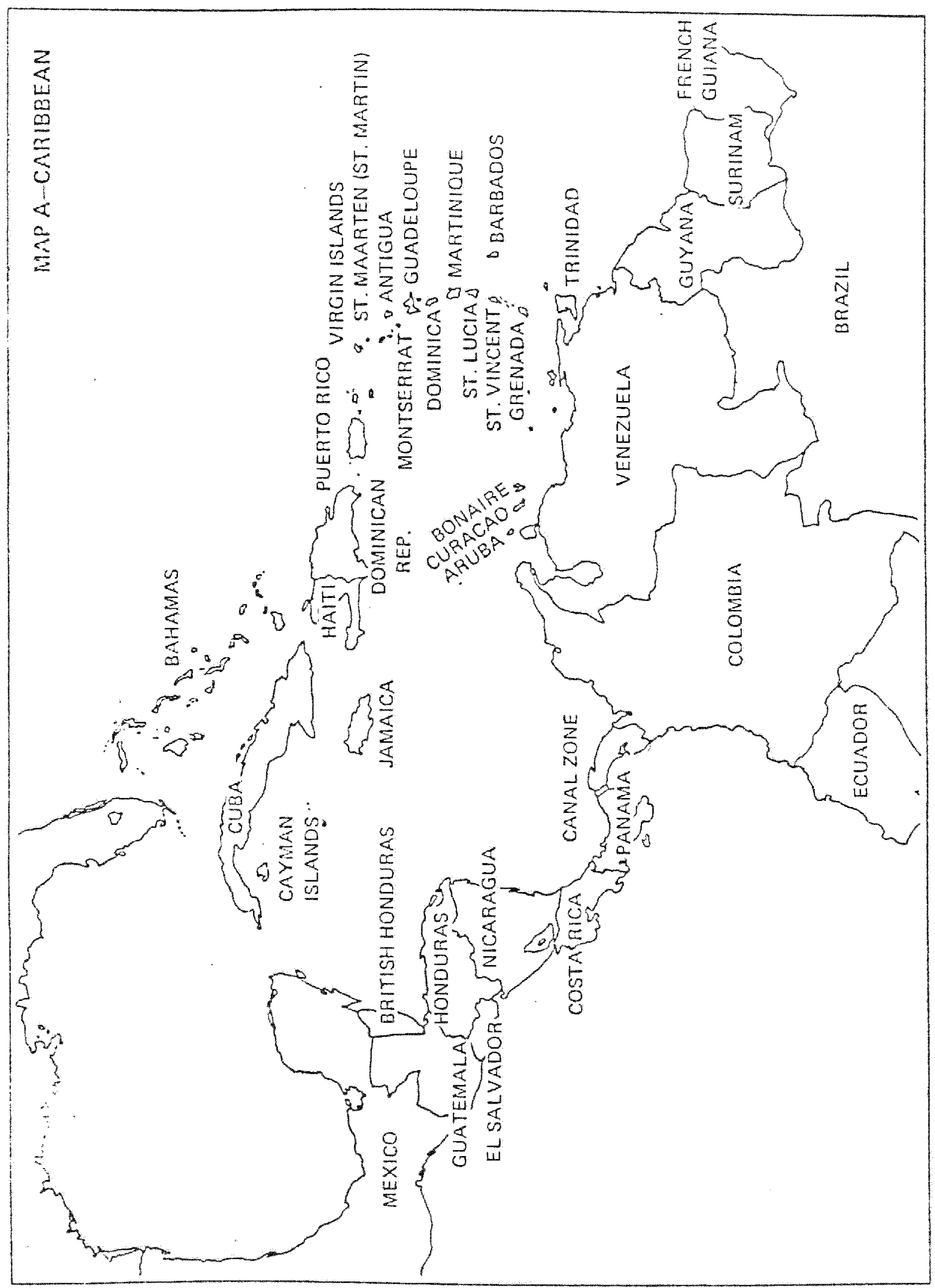

Source: Donald E. Lundborg, The Tourist Business 


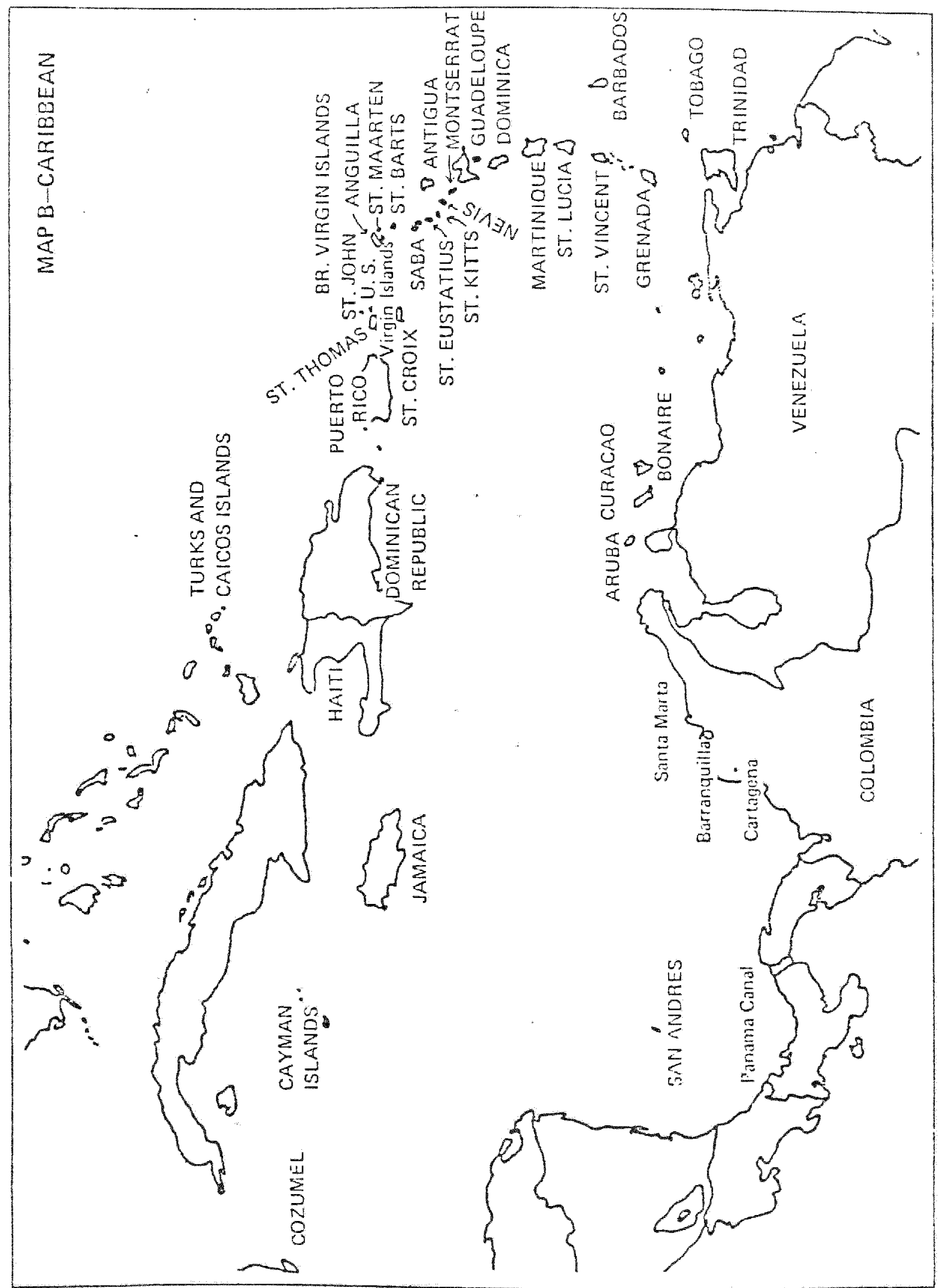

Source: Donald E. Lundberg, The Tourist Business 


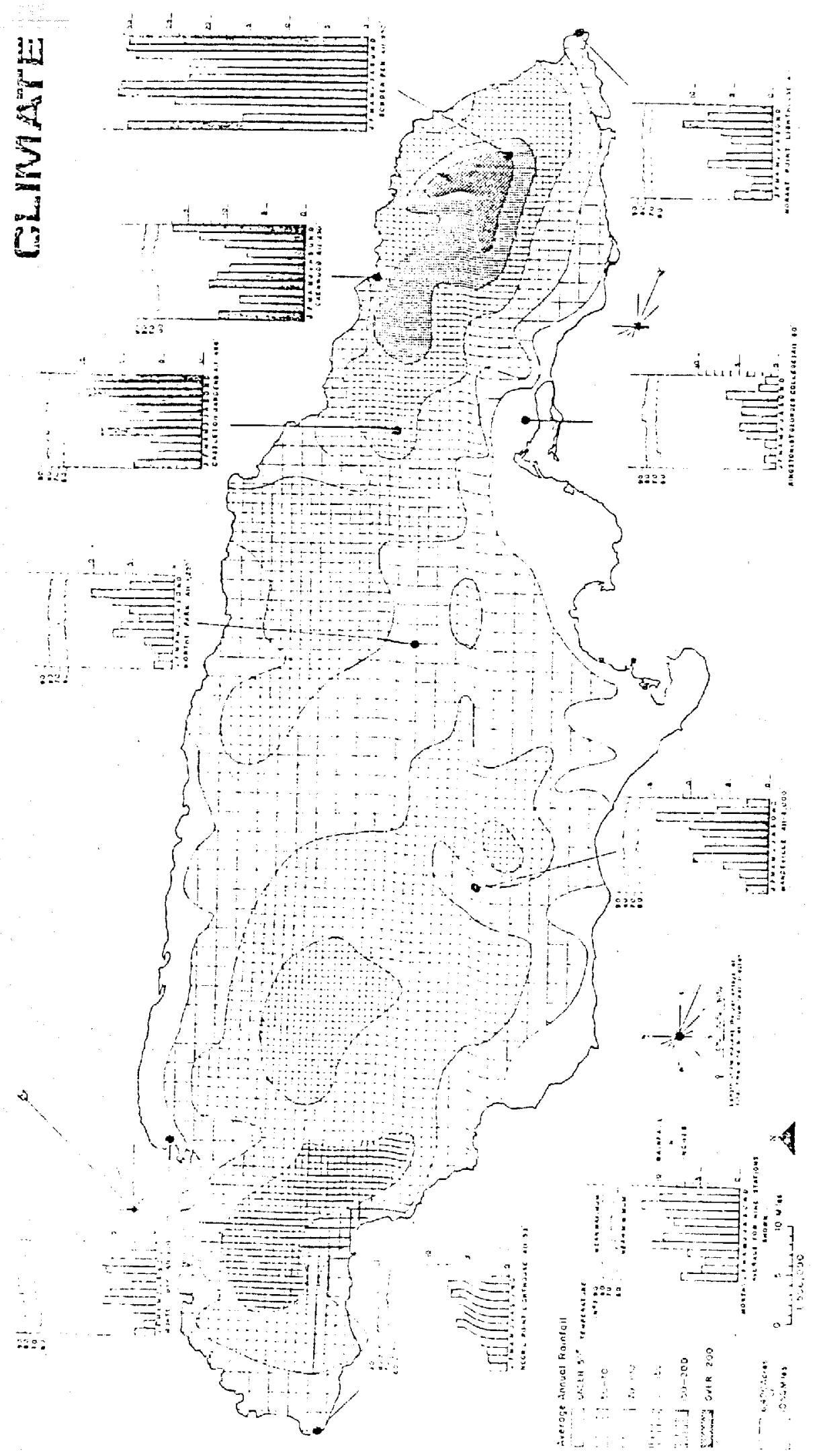




\section{Jamaica}

Jamaica is situated in the Caribbean Sea, South of the Eastern tip of Cuba, lying between latitudes $17^{\circ} 43^{\prime}$ and $18^{\circ}$ $32^{\prime} \mathrm{N}$., and 1ongitudes $76^{\circ} 11^{\prime}$ and $78^{\circ} 21^{\prime} \mathrm{W}$. It is approximately 100 miles southeast of Cuba and 100 miles west of Haiti. The island at its greatest length is 146 miles, its greatest width is 51 miles and its least width (from Kingston to Annotto Bay) is $221 / 4$ miles, covering a total land area of 4,411 square miles.

Jamaica has been described as "a long jagged spine of mountain set in a ring of plain". It has a chain of mountains running East-West through the central part of the island. The B1ue Mountains rise to 7,402 feet; more than half of its surface is about 1,000 feet above sea level, only 20 percent is flat compared to other West Indian Islands which are almost totally flat. There are many rivers flowing from the central mountains area but owing to the porous nature of the 1 imestone which covers over $50 \%$ of the interior, the rivers only appear intermittently. The rivers are usually narrow and fast-flowing, some have rapids. Limestone is no good for agriculture so most agriculture occurs in the valleys, the coastal plains are composed of mixed alluval clays and sands, about $60 \%$ of the land is used for planting, pasturing and forestry. Of the unutilized land, approximately $12 \%$ is potentially productive for agriculture, another $20 \%$ for forestry; $10 \%$ is permanent wasteland. Apart from its soil the 
only other natural resources of any importance is bauxite which occurs in the Limestone region. ${ }^{1}$

The climate is tropical with basically four seasons, two rainy seasons and two dry seasons distinguished mainly by the difference in rainfal1. However conditions vary depending on altitude and position.

Population

At the end of December, 1977 the population of Jamaica was estimated to be $2,109,400$.

Table II - 3

Demographic Statistics

\begin{tabular}{llllllc}
\hline & $\begin{array}{l}\text { Population } \\
\text { at 31 Dec. }\end{array}$ & $\begin{array}{l}\text { Mean } \\
\text { Year } \\
1977\end{array}$ & $\begin{array}{l}\text { Crude Birth } \\
\text { rate (per } \\
1000 \text { ) }\end{array}$ & $\begin{array}{l}\text { Death } \\
\text { Rate } \\
\text { (per } \\
\text { 1000) }\end{array}$ & $\begin{array}{l}\text { Rate of } \\
\text { Natural } \\
\text { Increase } \\
\text { (per 1000) }\end{array}$ & $\begin{array}{l}\text { Infant } \\
\text { Mortality } \\
\text { (per 1000) } \\
\text { live births }\end{array}$ \\
\hline 1972 & $1,953,500$ & $1,932,400$ & 34.3 & 7.2 & 27.1 & 30.9 \\
1973 & $1,990,900$ & $1,972,100$ & 31.4 & 7.2 & 24.2 & 26.2 \\
1974 & $2,025,000$ & $2,007,900$ & 30.6 & 7.2 & 23.5 & 25.9 \\
1975 & $2,060,300$ & $2,042,700$ & 30.1 & 6.9 & 23.2 & 23.5 \\
1976 & $2,084,200$ & $2,072,300$ & 29.3 & 7.1 & 22.2 & 20.3 \\
$1977^{*}$ & $2,109,400$ & $2,096,800$ & 28.9 & 6.8 & 22.1 & 15.1 \\
& & & & & & \\
\hline
\end{tabular}

"Provisional estimates from Registrar General's office.

Source: Economic and Social Survey, Jamaica 1977.

Iserdeo Jainarain, op. cit. p.66. 
Population by age and sex $\left(000^{\circ} \mathrm{s}\right)$

\begin{tabular}{|c|c|c|c|c|}
\hline \multirow{3}{*}{$\begin{array}{l}\text { Age } \\
\text { Group }\end{array}$} & \multicolumn{4}{|c|}{1976 October } \\
\hline & \multirow{2}{*}{ Male } & \multirow{2}{*}{ Female } & \multicolumn{2}{|c|}{ Tota1 } \\
\hline & & & Number & Percent \\
\hline $3-9$ & 284.1 & 285.6 & 596.7 & 27.4 \\
\hline $10-19$ & 266.5 & 270.2 & 536.7 & 25.8 \\
\hline $20-29$ & 132.0 & 147.6 & 279.6 & 13.4 \\
\hline $30-39$ & 84.8 & 97.0 & 181.8 & 8.7 \\
\hline $40-49$ & 75.2 & 85.5 & 160.7 & 7.7 \\
\hline $50-59$ & 74.1 & 69.0 & 143.1 & 6.9 \\
\hline over 60 & 100.5 & 110.7 & 211.2 & 10.0 \\
\hline
\end{tabular}

Estimates based on results of a demographic sample survey conducted by the Department of Statistics.

Source: Economic and Social Survey, Jamaica 1976.

Jamaica is a very racially mixed society. The National Motto is "Out of Many, one people", which gives an indication of the numerous racial groups, intermixing, yet in harmony. The principal racial groups are African, European, East Indian, Chinese and Syrians. The past three centuries of miscegenation has produced a society where every Jamaican carries with him some trace of some other racial strain. The majority of the population is of African origin, decendents of slaves brought to Jamaica between the 17 th Century and 1838 .

Migration abroad has been a part of the history of Jamaica. Between 1950-1960 over 200,000 Jamaicans emigrated to Britian. 
In recent years recorded migration from Jamaica has exceeded 20,000 per annum or more than 1 per cent of the total population. Since the virtual close of Britian to emigrants the migrants have been going to the U.S.A. and Canada. The result of adult migration and a high birth rate gives rise to serious problems. In 1911, children under 14 years of age represented less than 40 per cent of the population. In 1960, the proportion was about the same. However in 1975,45 percent of Jamaica's population was under 14 years of age. ${ }^{1}$ This places a heavy social burden on the remaining adult population.

\section{Main Streams of Jamaican Migration 1972-1977}

\begin{tabular}{|c|c|c|c|c|c|c|}
\hline Country & 1972 & 1973 & 1974 & 1975 & 1976 & 1977 \\
\hline \multicolumn{7}{|l|}{ United } \\
\hline States & 13,427 & 9,963 & 12,408 & 11,076 & 9,026 & $* \mathrm{n} . \mathrm{a}$ \\
\hline Canada & 3,092 & 9,363 & 11,286 & 8,211 & 7,282 & 6,230 \\
\hline $\begin{array}{l}\text { United } \\
\text { Kingdom }\end{array}$ & 1,620 & 1,872 & 1,397 & 1,397 & 1,198 & 1,029 \\
\hline \multirow[t]{2}{*}{ Tota 1} & 18,139 & 21,198 & 25,091 & 20,681 & 17,506 & n.a. \\
\hline & availab & & & & & \\
\hline So & ce: & mic and & Social Su & vey, Jam & ica 1977. & \\
\hline
\end{tabular}

The change in the direction of migration from Britain to North America is accompanied by a change in the type of migrant. The migration to Britain was mostly unselective. 
As Adam Kuper stated in his book "Changing Jamaica":

"Although various surveys suggest that the emigrants were on the whole more skilled, more experienced in urban employment, and perhaps better educated than the average Jamaican, none the less this migration certainly included large numbers of unskilled and unemployed men and women. The picture of the North American migration is very different." 1

The U. S. immigration laws which came into force in 1968, placed Jamaica in a Western Hemisphere group of countries which was given an entitlement of 120,000 immigrants per year. Jamaica took a large percentage of this figure, over 10 percent for many years. This was recently changed at the end of 1976 when each independent foreign state in the Western Hemisphere is given an annual 1imitation of 20,000 visas. ${ }^{2}$

Immigrants fall into two categories, either they are allowed into the U.S.A. because of a family relationship - that is, have a parent, child or spouse there, or the individual is awarded a "labor certificate", which favors special categories of workers, in particular skilled workers and craftsmen.

It is a noticable feature that more women that men are migrating which may have the effect of reducing the birth-rate in the future. Approximately 50 per cent of the migrants in 1976 were under twenty after having had several years to all of their education subsidized by Jamaica.

${ }^{1}$ Adam Kuper, op. cit., p.12.

${ }^{2}$ Economic and Social Survey, Jamaica 1977 , prepared by the National Planning Agency, Kingston, Jamaica. 
The Economy

With the demand for sugar in Europe in the 17 th Century, Jamaica was transformed into a "mono-culture plantation economy". Sugar cane necessitates large operating units and is heavily dependent on preferential markets. The twentieth century has not seen much in the change of the economies structure. Jamaica suffers from the same ailments as all other Caribbean territories, lacking land space, skilled manpower and having a very fast growing population and with the exception of Trinidad and Tobago lacking available sources of energy.

However Jamaica has the advantage of being the third largest territory in the Caribbean, topped only by Cuba and the island of Hispaniola shared by the two nations of Haiti and Dominican Republic. Although only 60 percent of the total land area is said to be presently utilized for productive use-planting, pasturing and forestry, at least another 24 per cent of the unutilized portion can be so used. This is much more than the productive land area of many of the smaller islands, in some cases even more acres than the islands themselves. When one realizes that many of these small islands are coral reefs where the soil is only a few feet thick, the picture emerges.

Whereas many of these small islands are flat, Jamaica possesses one of the highest mountain ranges in the Caribbean over 7,402 feet. The central spine of mountain running East to west produces varying rainfall quantities ranging from nearly 300 inches on the 
Eastern Blue Mountain slopes to less than 30 inches on some parts of the South-coast. ${ }^{1}$ Average rainfall for the island is $78.04 .^{2}$ This makes it possible to develop a level of subsistence agriculture beyond the scope of the smaller Caribbean islands and a greater range of export crops. Tropical crops can be cultivated in the hotter drier regions, sub-tropical crops and cattle-rearing in the cooler wetter areas. Agricultural crops include annotto, bananas, citrus, cocoa, coconuts, coffee, corn, ginger, pimento, pineapples, rice, sugar, tobacco. There is livestock development in process also fisheries and forestry.

The chief minerals worth mining in the island are bauxite, ceramic clays, marble, silica sand and gypsum. Jamaica is the second largest producer of bauxite and alumina.

In the last decade the manufacturing industry has been improving from processing of a few agricultural products to the production of a range of commodities dependent on local and imported raw materials. These include asbestos pipes, cement, chemicals, clothing, footwear, glass, metal products, petroleum products, rum, paper products, textiles and tobacco.

Finally, there is tourism. Since the end of the second World War, the tourist industry has grown to be one of the major foreign exchange earners.

${ }^{1}$ Statistical Yearbook of Jamaica 1977, p. 10. 2 Ibid. 


\section{Tourism in the Caribbean}

Tourism seems tailored for the Third World developing countries in particular the tropical region called the Caribbean. Governments of these islands, possessing abundant supplies of sun, warm climates, in addition to Third World poverty, limited resources and physical 1 and and people constraints, have found it necessary to embrace tourism. The objectives were basically:

-- to revive the once flourishing sugar-cane producing economies that have falled into decline as in Puerto Rico and Barbados,

-- to serve as an impetus for the development of other industries and the achievement of national development goals as in Jamaica, Mexico, Portugal, Brazil and Turisia. ${ }^{1}$

- to act as a political and cultural bridge between the developed tourist generating economies and the various host countries, while creating a multiplier effect for local cultural expressions.

For the island economies of Bahamas, Bermuda and U.S. Virgin Islands, tourism represents their major industrial activity. In

${ }^{1}$ James J. Eyser, "Economic and Development and Public Policy: Tourism as an Alternative", Cornell Quarterly, November, 1976. 
1975 the Bahamas received 1.4 million visitors and the Industry accounted for about half of the nations $\$ 130$ million tax revenue and about 70 per cent of its G.D.P. 1

In Bermuda it is estimated that about US $\$ 210$ million is spentannually by tourists, contributing about 68 percent of total Foreign Exchange earnings and is the largest employer. Definition of Tourism

Jafar Jafari in the editor's page of "Annals of Tourism Research" provides a short simple yet adequate definition of tourism:

"Tourism is a study of man away from his usual habitat, of the industry which responds to his needs, and of the impacts that both he and the industry have on the host socio-cultural, economic and physical environment."

(2)

Reasons for Tourism Development in the Caribbean

For the Caribbean, tourism is seen as a highly desirable and feasible method to achieve increased economic development. The topography, cultural attractions and low cost labor are abundant in the region. All that seem to have been needed was the construction of the hotel superstructure--the hotel accommodations and recreation facilities, and supporting infrastructure-the roads, airports, public utilities to put the tourism sector in motion. There is a "short gestation period" involved and tourism could produce revenues within 1 to 2 years after a strong advertising campaign. Tourism as an invisible export earns Foreign

${ }^{1}$ Somerset Waters and William Patterson, ASTA Travel News, The Big Pichire Travel 1976 (New York, Travel Communication 1976) p. 42 .

Jafar Jafari, "Annals of Tourism Research", Volume V, Oct./Dec. 1977. 
Exchange without the remittance of a nation's natural resources. The only materials escaping are local souvenirs and craft work. The earnings of convertible currency by developing countries is urgently needed to reduce the greatly increasing balance of payments deficits. This situation has been the result of the growing demand for imports by these developing countries which has been coinciding with $10 \mathrm{w}$ and even declining growth rates in export of primary commodities. Foreign Exchange is required to pay for the badly needed manufactured and semifinished products needed to keep economies going. Earning of Foreign Exchange is often preferable to begging economic aid from developed countries. Today with the increased cost of oil, intense competition among Caribbean destinations develop for the tourist market and dollars with all the adverse effects involved with such program. In this battle for "survival" only the fittest" can survive--those territories who politically, socially, culturally and economically showed balanced development.

Tourism promises large-scale reduction of the unemployed and maximum usage of the unskilled and semi-skilled, in addition to growth in the agricultural sector in response to increased demand of the tourism industry and a stimulus to overall development of other industries via the multiplier effect of tourism expenditures.

International tourism has tended not to show the sudden fluctuations in demand on a yearly basis in the same way that the commodity trade does. It's hard to predict export revenues 
too far in advance as it varies with supply and demand that is, volume and its corresponding price. Commodity Trade has not provided an increase in revenues to match increased import volume requirements and increased price of imports. Tourism market potential is good. In addition, the tourist markets in developed countries are not very protected as primary commodities markets are. Tourist markets are more easily accessible. Attempts by developing countries to use their comparative advantage in terms of labor costs for manufacturing has been frustrated by both limited domestic markets and restricted access to foreign markets via tarriffs and quota barriers. These mechanisms protect the developed countries' markets higher cost home industry from the relatively cheaper imports.

By the standards of traditional commodities tourism is stable. Until 1974 tourism was one of the few commodities where Third World developing countries has been consistently increasing their share of the world market.

The question has often been asked of what is the "opportunity cost" of tourism. Whether by employing the resources, the residents, on jobs directly and indirectly related to the tourism product, is there a cost involved, the cost of alternative productive employment?

According to Donald Lunberg, this type of analysis may have little meaning for many Caribbean destinations where other means of employment have been tried and proved uneconomical. I 
He states that the Bahamas tried producing pineapples, cotton, fishing--even rum running--but none proved economical, therefore, the "opportunity cost" for tourism employment in the Bahamas under present conditions is small, as few other opportunities exists. 1

The Bahamas and most of the smaller Caribbean Islands can barely subsist as agricultural economies. Per capita income on some of the islands is less than $\$ 400$ a year. They are too remote to be competitive as small manufacturers. They have little choice but to consider tourism for future development.

The major thrust of the promotional efforts of the Caribbean has been the developed Western markets, who possess the valuable convertible, currency backed by silver or gold, where standards of living are high. There are high rates of economic growth, where the bulk of the population is urbanized and mass media is very developed. These countries are the United States of America, Canada, Federal Republic of Germany and Great Britain. Tourism involves a redistribution of income and. wealth from these developed countries to the developing Third World economies of the Caribbean and also redistribution of income on the local domestic level.

Trends in Tourism Development in the Caribbean

Tourism development in the Caribbean has certain common elements with other tourist developments elsewhere.

\footnotetext{
${ }^{1}$ Donald Lundberg, op. cit., p. 150. 2 Ibid.
} 
1. "The area must be conveniently accessible to sizable markets." The Caribbean is a short distance away by aircraft and there are regular flight schedules to Caribbean destinations from the North American Continent and the Eastern seaboard of the U.S. in particular.

2. "The cost of transportation to the destination area must be relatively reasonable". The travel cost has been decreasing even further with the trend towards increased use of charters and pre-paid inclusive tours as the tourist industry become more "mass" oriented.

3. "Hotel accommodations must be relatively plentiful and preferably available in a range of prices". This request is easily complied with for the more tourist developed Caribbean destination.

4. "Promotion and advertising is necessary to keep the destination area in the eye of the potential traveller to the area". The National Tourist offices for the individual territories, often located in the tourist-generating economies is primarily involved with the achievement of this objective. 
5. "The destination area must give the traveller the impression he is welcome and wanted". Today with achievement of independence by many Caribbean islands and growing nationalism and local pride this is harder to achieve. Most importantly the maturing phase of tourism for most territories in the Caribbean region carries its own implication. The vicious circle seems to be at the third stage of development. First was the eagerness for the tourist dollar; next came wide-scale tourist development via Government incentives and legislation, and finally the recognition by many that tourism has been providing an inadequate return to the people.

6. The area must offer a variety of attraction and experience which the Caribbean has--night life, duty-free shopping, beach, water sports, and cultural entertainments.

Statistics on the tourism sector of OAS member states which includes the Caribbean show that for the years 1970-1977 the number of arrivals increased by an average of 9.1 percent annually. For the period 1974-1977 which saw a world energy crisis, recession and a later recovery, arrivals was even showing a higher percentage rate of 12.3 percent. 1

1 Thomas Reigert "Statistical Bulletin of the OAS", January-March 1979. 
Income for the same OAS member states from tourists increased by an average of 12.0 percent for the period 1970 1977 but only 6.5 percent during the years 1974-1977.1

The trend in the Caribbean has been for a receipts from tourism to be much slower than increase in arrivals. This is indicative of the tourist's success in economizing costs, greater use of charters, cheaper accommodations and prepaid inclusive tours. In addition as the tourist market moves from "class" to "mass", "the length of stay" also declines. Another reason for the wholesale group charters is that into a group package tour is built experiences people want at a price they are willing to pay, while safety in numbers is reassuring.

According to OAS, the lowest rates of growth was registered in Mexico and the Caribbean, partly the result of the maturity of tourism for both places as well as the results of disturbances in Jamaica and Grenada for the period 1974-1977.

$1_{\text {I } \text { Iid. }}$. 
Graph I

GROWTH OF TOURIST ARRIVALS

IN SELECTED AREAS

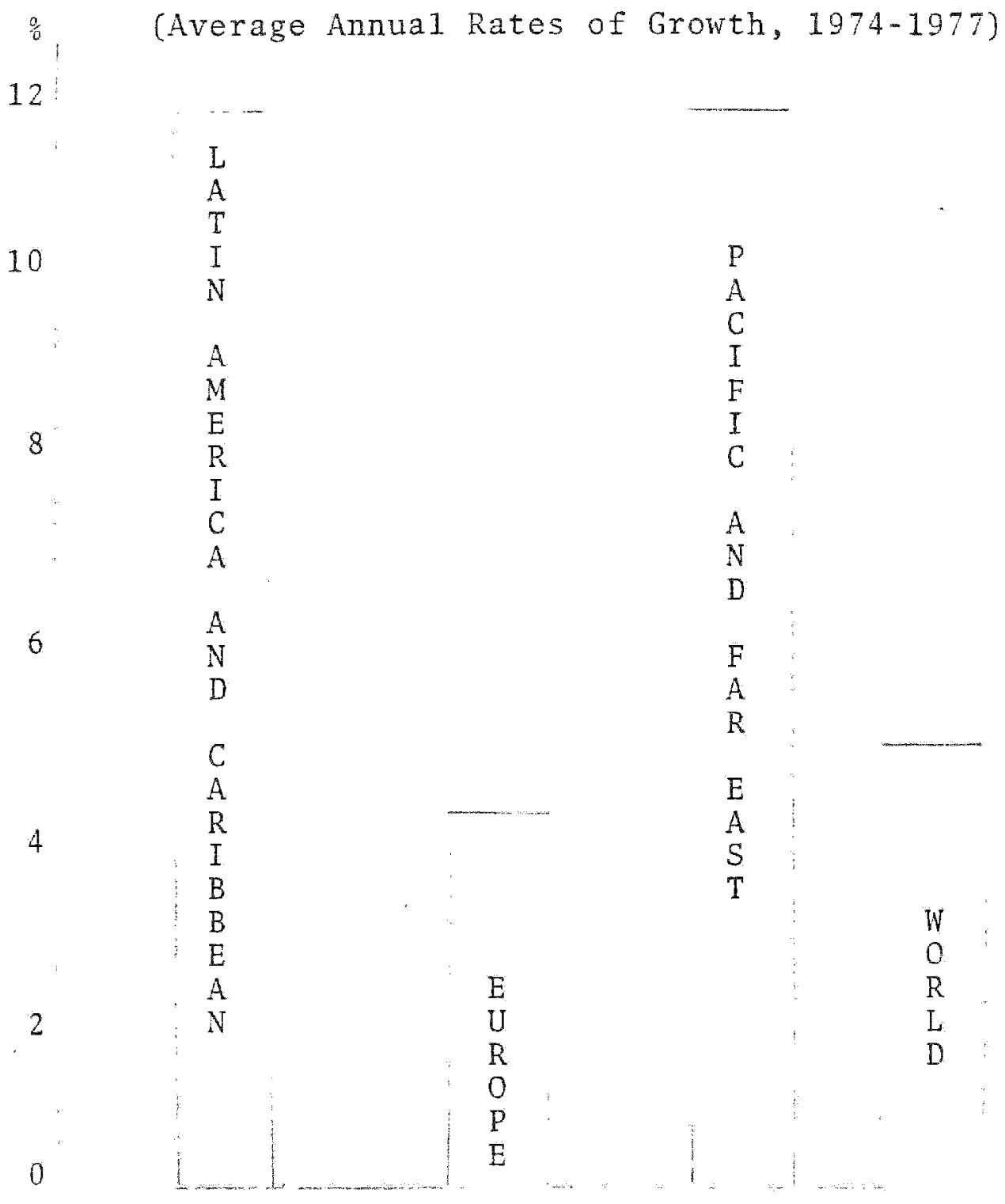

Source: OAS 
Statistics for visitor arrivals by air in the Caribbean is presented in Table II 4.

Table I I -4

CARIBBEAN VISITORS ARRIVING BY AIR

Country

Antigua

Aruba

Bahamas

Barbados

Bonaire

British Virgin Islands

Cayman Islands

Cuacao

Dominica

Dominican Republic

Greneda

Guadeloupe

Haiti

Jamaica

Martinique

Montserrat

Puerto Rico

St. Kitts-Nevis

St. Lucia

St. Maarten

St. Vincent

Trinidad \& Tobago

Turks \& Caicos
U.S. Virgin Islands

$\begin{array}{rrrc}70,140 & 71,065 & 68,897 & 62,114 \\ 88,078 & 93,028 & 100,814 & 123,000 \\ 1,044,973 & 1,021,842 & 966,560 & 917,000 \\ 208,995 & 220,753 & 230,718 & - \\ 8,067 & 10,883 & 11,102 & - \\ 22,000 & 24,995 & 29,194 & 31,737 \\ 30,646 & 45,751 & 53,104 & 54,000 \\ 126,683 & 123,192 & 109,263 & 103,304 \\ 14,737 & 14,904 & 16,298 & 16,805 \\ 91,451 & 134,152 & 168,000 & 235,000 \\ 35,081 & 30,620 & 13,751 & 19,451 \\ 42,160 & 42,554 & 57,495 & 72,000 \\ 67,625 & 70,000 & 79,063 & 79,000 \\ 404,704 & 415,157 & 406,381 & 377,530 \\ 68,947 & 82,798 & 108,784 & -- \\ 10,449 & 10,500 & 10,141 & -- \\ 1,172,885 & 1,322,258 & 1,441,002 & 1,339,137 \\ 15,991 & 14,773 & 13,120 & 14,480 \\ 41,586 & 43,902 & 48,585 & 44,040 \\ 108,980 & 107,916 & 110,018 & -- \\ 15,701 & 15,594 & 19,242 & -- \\ 112,350 & 123,570 & 126,550 & - \\ 4,390 & 5,575 & 7,604 & 7,760 \\ 774,474 & 720,876 & 622,647 & --\end{array}$

Source: Caribbean Travel Association and Childs \& Waters, Inc. 
For the year 1975, traffic to the Caribbean declined by about 6 percent. The decline was more pronounced in the larger resort areas which already had a surplus of hotel rooms. Some hotels closed, others were taken over by Governments. Some of the smaller islands were capturing a larger share of the tourist market from the older more established resort areas.

The figures for cruise passengers indicate that between 1974 and 1977, cruise ship passengers have been on the increase. Cruise ship passengers live aboard the ship and therefore spend less than tourists living at a destination.

Table II-5 gives cruise ships passenger arrivals for selected Caribbean territories and the annually average growth rates for the period $1970-1977$.

Table II - 5

Arrivals of Cruise-Ship Passengers in

Selected Countries, 1970-1977

Subregion

and

Country

1970

1974

1975

1976

Annual average

growth rates $(\%)$

CARIBBEAN

Barbados

$79,635 \quad 119,524$

98,546

$95,901 \quad 103,077$

$3.8-4.8$

Grenada

n.a. $\quad 57,644$

85,460

$106,882108,465$

n.a 23.5

Haiti 28,613

129,911

196,667

$201,808 \quad 186,433$

$31.0 \quad 12.7$

Jamaica

105,598

97,739

157,449

$142,008 \quad 121,593$

3.27 .6

Sources: Statistical bulletins of national tourism authorities.

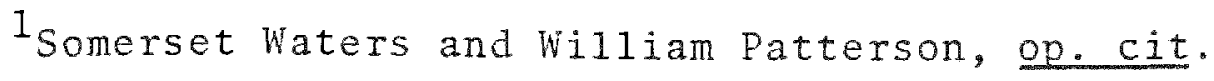


For the year 1974, total earnings from tourism in the Caribbean was estimated at about $\$ 2$ billion, according to a study published by the Federal Reserve Bank of Atlanta. 1976 showed greater promises of increases in arrivals and the $\$ 2$ billion mark should be surpassed.

Foreign-exchange earnings from tourism for OAS member states of Mexico, Central America and Panama, Caribbean Andean Group, Southern Cone and Brazil is presented for 19701977 in Table II-6 as a possible comparison, also the annual average growth rates. Table II-7 gives an idea of the contribution of tourist expenditures to Balance of Payment for the same OAS member states including the Caribbean. 
गे।

-

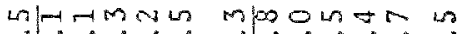

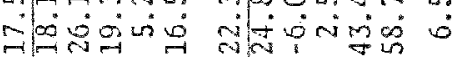

गेण

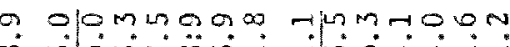

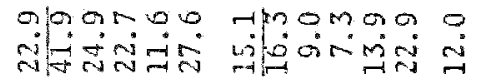

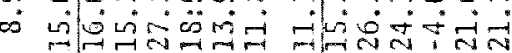

फा वे से ฯ voon $\hat{\sim}$

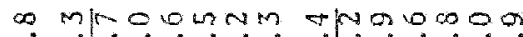
लु si

$\stackrel{20}{\circ}$

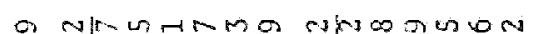

0
9
9 $\therefore$

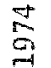

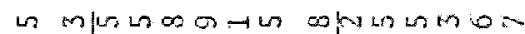

出 $\mathrm{si}^{3}$

$\stackrel{0}{2}$

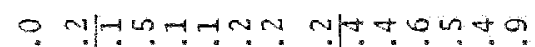

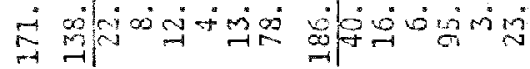

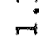

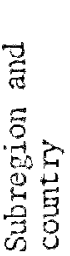

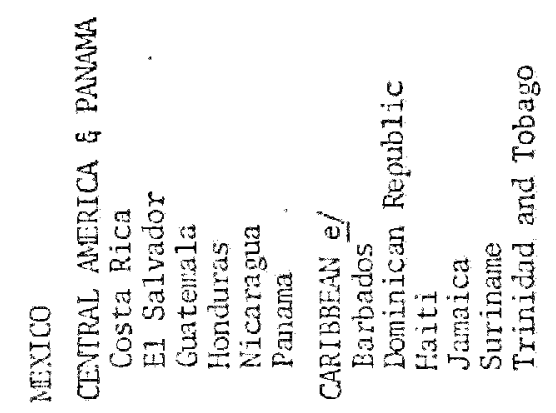

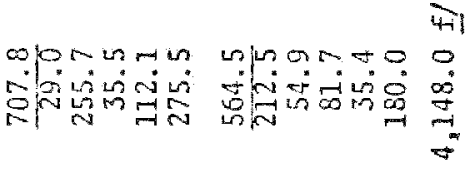

m|rmmo m|

aponar okguma o

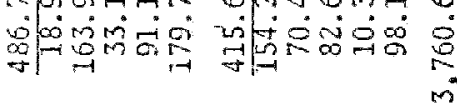

oponant matrogon

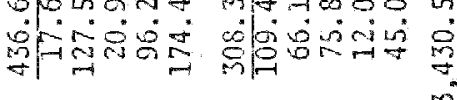

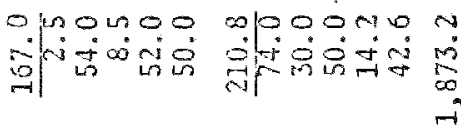

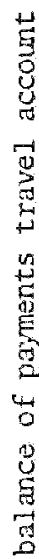

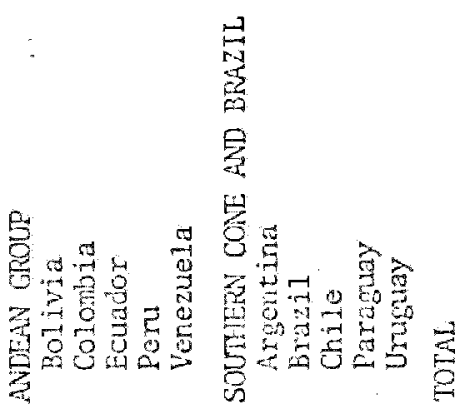


TABLE II - 7

CONTRIBUTION OF TRAVEL EARNINGS TO BALANCE OF PAYENTS, SELECTED YEARS (in percentages of total exports of goods and non-factor services

\begin{tabular}{|c|c|c|c|c|c|}
\hline $\begin{array}{l}\text { Subregion and } \\
\text { country }\end{array}$ & 1970 & 1974 & 1975 & 1976 & 1977 \\
\hline MEXICO & 39.9 & 31.6 & 33.3 & 30.3 & 26.3 \\
\hline $\begin{array}{l}\text { CENTRAL AMERICA \& PANAMA } \\
\text { Costa Rica } \\
\text { El Salvador } \\
\text { Guatemala } \\
\text { Honduras } \\
\text { Nicaragua } \\
\text { Panama }\end{array}$ & $\begin{array}{r}8.1 \\
7.8 \\
3.5 \\
3.4 \\
2.0 \\
5.9 \\
19.7\end{array}$ & $\begin{array}{r}7.2 \\
8.7 \\
2.9 \\
7.2 \\
2.7 \\
4.8 \\
11.2\end{array}$ & $\begin{array}{r}7.5 \\
8.3 \\
2.9 \\
8.8 \\
2.9 \\
5.4 \\
10.6\end{array}$ & $\begin{array}{r}\frac{6.3}{7.4} \\
2.4 \\
5.3 \\
2.4 \\
4.4 \\
11.9\end{array}$ & $\begin{array}{l}\frac{\text { n.a. }}{6.4} \\
2.1 \\
4.3 \\
2.3 \\
\text { n.a. } \\
12.3\end{array}$ \\
\hline $\begin{array}{l}\text { CARIBBEAN a/ } \\
\text { Barbados } \\
\text { Dominican Republic } \\
\text { Haiti } \\
\text { Jamaica } \\
\text { Suriname } \\
\text { Trinidad \& Tobago }\end{array}$ & $\begin{array}{r}10.9 \\
39.2 \\
6.2 \\
13.2 \\
17.9 \\
1.9 \\
4.0\end{array}$ & $\begin{array}{r}7.0 \\
37.2 \\
6.9 \\
14.2 \\
11.9 \\
1.9 \\
2.6\end{array}$ & $\begin{array}{r}6.8 \\
32.5 \\
5.6 \\
11.9 \\
10.7 \\
1.5 \\
3.4\end{array}$ & $\begin{array}{r}6.6 \\
35.8 \\
8.0 \\
9.7 \\
10.2 \\
2.4 \\
2.8\end{array}$ & $\begin{array}{r}\frac{\text { n.a. }}{38.0} \\
8.7 \\
10.6 \\
6.6 \\
\text { n.a. } \\
\text { n.a. }\end{array}$ \\
\hline $\begin{array}{l}\text { ANDEAN GROUP } \\
\text { Bolivia } \\
\text { Colombia } \\
\text { Ecuador } \\
\text { Peru } \\
\text { Venezuela }\end{array}$ & $\begin{array}{l}3.0 \\
1.4 \\
5.3 \\
3.5 \\
4.2 \\
1.7\end{array}$ & $\begin{array}{l}2.4 \\
2.7 \\
6.3 \\
1.5 \\
5.0 \\
1.4\end{array}$ & $\begin{array}{l}\frac{3.0}{3.4} \\
7.1 \\
2.5 \\
5.1 \\
1.8\end{array}$ & $\begin{array}{l}3.3 \\
3.8 \\
6.4 \\
2.1 \\
5.5 \\
2.1\end{array}$ & $\begin{array}{l}\frac{3.7}{3.9} \\
7.4 \\
2.3 \\
5.1 \\
2.5\end{array}$ \\
\hline $\begin{array}{l}\text { SOUTHERN CONE \& BRAZIL } \\
\text { Argentina } \\
\text { Brazil } \\
\text { Chile } \\
\text { Paraguay } \\
\text { Uruguay }\end{array}$ & $\begin{array}{r}3.0 \\
3.4 \\
1.0 \\
3.9 \\
15.7 \\
14.8\end{array}$ & $\begin{array}{l}\frac{1.8}{2.3} \\
0.7 \\
3.1 \\
5.5 \\
9.0\end{array}$ & $\begin{array}{r}2.6 \\
4.2 \\
0.7 \\
4.7 \\
4.4 \\
17.3\end{array}$ & $\begin{array}{l}\frac{2.1}{3.8} \\
0.5 \\
3.6 \\
5.3 \\
9.5\end{array}$ & $\begin{array}{r}2.3 \\
3.2 \\
0.4 \\
3.1 \\
8.4 \\
20.2\end{array}$ \\
\hline TOTAL & 9.9 & 6.8 & 7.8 & 7.1 & $6.6 \mathrm{~b} /$ \\
\hline
\end{tabular}

a. Excludes Grenada

b. Estimate

Source: Intemational Monetary Fund, Balance of Payments tapes. 
For Barbados tourism accounted for 2.5 of total earnings from goods and services in 1977. In Jamaica the industry saw a period of decline in receipts.

A study of the attitude of 1,400 travel agents towards the Caribbean, Mexico, Central and South America was conducted by a faculty group from Cornel1's School of Hotel Administration and Robinson's, Inc., of Orlando, Florida in 1975. 1

The results showed that the attitude of U.S. travel agents was slightly more favorable towards the Caribbean than toward Latin America. In "perceived attractiveness: the five regions were ranked as following: Andean Countries, Caribbean, Southern South America, Mexico, Central America.

In "perceived cleanliness", the ranking order was: Caribbean, Southern South America, Andean Countries, Central America, Mexico.

In "perceived safety", the ranking order was: Mexico, Caribbean, Andean Countries, Central America, Southern South America.

In "perceived friendiness", the order of ranking was:

Mexico, Central America, Southern South America, Andean Countries and lastly the Caribbean. For both "popularity" and"activity" Mexico was ranked first, the Caribbean next, followed by Southern South America, Central America, Andean Countries.

$1_{\text {peter Yesawich and John Duncan III, "Survey of Attitudes }}$ of U. S. Trave1 Agents", Corne11 Quarter1y, May 1975. 
For all destinations the net operating profit is a function of (1) tax placed on the industry, (2) average tourist expenditures, (3) average occupancy rates. With the exception of local tariff situation the other deciding factors are externally determined from the host territory. The small Caribbean territory has no control over the income of the tourist in their home countries, in addition these small host countries are also vulnerable to economic fluctuations in the countries of origin of the tourist. Many of the Caribbean resort destinations have tried to reduce dependency on the tourist generating capacities of the U.S.A. and Canada and are actively seeking the European market. The fuel shortage and increased oil cost however have demonstrated a trend for reduction in the demand for long-haul destination points as the Caribbean is to the European tourist markets. As a result the international traveller from Europe stays increasingly closer to home in the same manner in which the Americans will choose vacation destinations nearby.

Who is the Tourist to the Caribbean

The Caribbean in general appeals to the North American middle class. For North Americans, the Caribbean projects balmy breezes, the 1 imbo dance, straw markets, new hotels set in scenic beauty. 1

${ }^{1}$ Donald Lundberg, op. cit., p. 239. 
-.-"because it seems to approximate to the romantic myths of the paradise isle or the tropical Eden. The younger, more fashion-conscious tourists may add freely available dope, reggae music and a touch of Rastafarian mysticism to the basic idyllic ingredients, but their attitude remains equally "mystified". Since the mythology of escape is indispensible to tourism it is not easy to reject the paradisal imagery." (1)

The mass tourist to the Caribbean is there on a vacation from the anxieties and frustrations to his world back home. He cannot be expected to be interested in the social and economic issues of small island nations struggling to see their way in a world of economic turmoil and Third World poverty. He is not interested, not when the destination has been sold to him either by his travel agent or by the host country's Government Tourist office in his home country. The tourist has come "in search of a world of pleasure, and island of lotus eaters". ${ }^{2}$ He expects the beaches to be clean and the native welcoming. Anything other than his expectations makes him feel cheated and angry. He does not want to know the reason behind the poliuted beach and the hostility of the local peoples, that they hate to be called "natives". He has spent his money and wants his money"s worth.

The tourist to the Third World nations and the Caribbean has rigidly polarized views of the world. He sees no connection between the wealth of his class and the poverty he sees. The

${ }^{1}$ Louis Turner and John Ash, op. cit., p. 206.

${ }^{2}$ Ibid. 
Caribbean tourist is often exposed to extremes of wealth and poverty not witnessed in Europe and other developed countries. often he feels superior to the local people and regards himself as their saviour.

For many independent Caribbean countries although the industry is courted, many local people will reject it for demanding too much subservience. The white tourist has replaced the old colonial masters. 


\section{CHAPTER III}

This chapter provides an overview of Jamaica's economic performance for 1976,1977 and 1978 and presents the sectoral contributions of Agriculture, the Mineral Industry, Manufacturing Construction and Installation, and Tourism to Gross National Output, Foreign Exchange Earnings, employment and general overall development.

\section{THE ECONOMY}

Like most developing countries Jamaica is a producer and exporter of primary products and an importer of manufactured goods, capital and industrial raw materials, that is, secondary products. The nature of this trading agreement has been increasingly disadvantageous for developing countries.

The trend of rising prices for secondary products and oil in addition to unstable world prices for primary products becomes accentuated. The overall import price index grew by 139 percent between 1973-1976 for Jamaica. ${ }^{1}$ Exports have not kept pace with this increase. The result is a largely increasing adverse balance of trade with its implications for the balance of payments.

The year 1975 saw a steadily worsening economic situation in Jamaica with both the Visible Balance of Trade and Balance of Payments showing considerable increases over 1974. 1976 saw no improvements due to drought and political develop-

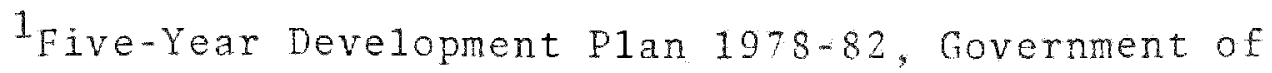
Jamaica. 
ments in Jamaica. The major difficulties were centered on the external sector resulting in reduced foreign exchange earnings and capital inflows and depleted foreign exchange reserves.

There was both a fall in export earnings and importations. The fall in import demand was due to a deliberate government policy aimed at reducing the outflow of foreign exchange. A total ban was put on the importation of motor vehicles and an increased consumption duty placed on both consumer and capital goods. Limits were put on categories of goods to be imported and local production was encouraged via government incentives. However the incentives had a nominal effect due to frequent industrial disputes and labor unrest within the export-oriented sectors. In particular, the Bauxite and Alumina Industry were most affected where production declined below the 1975 leve1. In addition adverse publicity and reports of violence within the country reduced tourist arrivals by approximately 15 percent and estimated tourist expenditure by 18 percent. ${ }^{1}$

Due to the import-restriction measures, the merchandise trade deficit of $\$ 254$ million in 1976 was lower than in 1975 (\$281 miliion). The real problem was in the Capital accounts. Private outflows of capital was considerable and private inflow insubstantial. A net private outflow of $\$ 90$ million was recorded. However the illegal outflows was estimated to be about $\$ 300$ million in the years 1974-1976. The net capital inflows in 1976 totaled only $\$ 50.5$ million, compared to 1975 
when it was $\$ 189.9$ million. Foreign exchange reserves of $\$ 240.5$ million had to be used to finance the current account deficit. By the end of 1976, gross foreign reserves had fallen to the minimum required to finance daily transactions. New measures were adopted to contract import demand, and increase exports while new external financing was sought. Additional Taxation had been introuduced early in 1976 but revenues were adversely affected by falling exports and domestic production. ${ }^{1}$

In the elections of December 15, 1976 the Jamaican populace supported the ruling party's ideology of Democratic Socialism and their policies of social reform and economic sovereignity. However the poor performance of the basic producing sectors and depletion of foreign exchange reserves at the end of 1976 made it increasingly difficulty to maintain the existing programmes.

The year 1977 commenced with a government announcement of a new package of additional taxation and tighter foreign exchange and import controls. An import ceiling of $\$ 600$ million, later revised to $\$ 800$ million was set, with priorities given to raw materials particularly those intended for export industries and basic food. One of the conditions of the loan from the International Monetary Fund was a partial devaluation of the Jamaican dollar. In April 1977 the devaluation was $371 / 2$ percent and a dual exchange rate system established.

${ }^{1}$ Economic and Social Survey, Jamaica 1976, op.cit. 
Under this "two-tiered" rate system, there was a basic or original rate and a special rate equivalent to 37,5 percent devaluation. The basic rate was the original rate of exchange of J\$1. - U.S.\$1.10. This rate was applied only to importation of certain basic commodities and transactions relating to the Government or bauxite/alumina industry. The special rate representing the 37.5 percent devaluation of the Jamaican dollar was set at J\$1 = U.S.\$0.80 or U.S.\$1.00 = J\$1.25. A11 commodities with the exception of bauxite and alumina were exported at the special rate.

In October 1977, six months later, there was a further devaluation of the special rate by 2.5 percent completing the round at 40 percent. The special rate moved from $J \$ 1.25$ to $J \$ 1.28=U . S . \$ 1.00$.

The strategy was aimed at restricting non essential consumer items and capital equipment. About 72 percent of all imports was classified "essential" and were imported at the basic rate. The effect, therefore, on the import sector was not as severe as a full devaluation strategy would have been and the value of the imports could be maintained within the revised $\$ 800$ million level. Serious shortages of raw materials and products resulted. Domestic agriculture increased but this was still insufficient to meet demand.

Devaluation in general has the effect of making the exports of the devaluating countries more competitive vis-a-vis similar exports of other countries. It was expected to give a boost to Jamaica's exports, particularly, the nontraditional 
exports as the traditional exports are sold under prearranged trading agreement. 1

The measures adopted to stem the outflow of foreign currency by restricting imports and stimulating exports were still insufficient. The International Monetary Fund provided a stand-by agreement making available a loan of U.S. $\$ 74$ million to be paid in installments. U.S. \$24.4 million was paid during $1977 .^{2}$ A further U.S. $\$ 22.0$ million due in December 1977 was not paid as one of the conditions of the loan, that of net domestic assets test was not met. Balance of Payment support was provided by other loans and lines of credit from some of Jamaica's trading partners.

Overall there has been a negative real growth of about 11 percent between the years 1972-1977..$^{3}$ Table III-1 gives the annual growth rate of the G.D.P.

TABLE III - 1

Gross Domestic Product (constant 1974 prices), 1977 - \$2011.1.

Annual rate of growth by G.D.P. (constant 1974 prices)

$\begin{array}{ll}1971 / 1970: & +2.4 \% \\ 1972 / 1971: & +9.3 \% \\ 1973 / 1972: & -0.1 \% \\ 1974 / 1973: & +0.3 \% \\ 1975 / 1974: & -1.0 \% \\ 1976 / 1975: & -6.7 \% \\ 1977 / 1976: & -4.0 \%\end{array}$

Source: Five-Year Development Plan (1978-82 Govermment of Jamaica)

${ }^{1}$ Economic and Social Survey, Jamaica 1977 , op.cit. p. 49

${ }^{2}$ External Trade 1977 , Department of Statistics, Jamaica.

${ }^{3}$ Five-year Development Plan 1978-82, Government of Jamaica. 
The distribution of real G.D.P. has also fallen as depicted in Table III-2 for the period 1971-1977.

TABLE III -2

\section{INCOME DISTRIBUTION}

Real G.D.P. per capita (1974 prices)

$1971 \quad \mathrm{~J} \$ 1,088.2$

$1976 \quad J \$ 1,010.6$

$1977 \quad$ J\$ 959.5

Change $(1971-1976)-7.2 \%$

Change $(1971-1977)-11.9 \%$

Source: Five Year Development Plan 1978-82 Government of Jamaica

When the influence of price changes is removed, the output of goods and services at constant values produced in 1977 declineł by 4.0 percent instead of the reported 9.1 percent indicated by current value measurements. This is depicted in Table III-3 
TABLE III - 3

Gross Domestic Product by Economic Activity in Purchasers' Values at Constant Prices

$(\$ 000)$

Industry

and Fishing

1973

1974

1975

1976

1977

Sugar Cane

Other Main Exports

33,109

21,048

Domestic Agriculture

Root Crops

Other Primary Prod.

Livestock \& Hunting

Fishing

Forestry \& Logging

Mining and Quarrying

Bauxite \& Alumina

Quarrying Incl.

Gypsum

Manufacture

Construction \& Installation

Electricity \& Water

Transportation, Storage $\&$ Conmunication

Distributive Trade

(Wholesale \& Retail)

Financial Institution

Real Estate

Products of Government Services

Miscellaneous Svcs

Households \& Private Non-Profit Inst.

Less Imputed Service Charges

12,061

65,993

37,071

28,922

38,931

17,052

4,316

261,895

251,403

10,492

379,918

230,827

22,221

123,856

491,561

86,156

173,206

222,895

129,593

43,246

65,878
159,401

162,645

36,479

22,226

14,253

70,154

40,338

29,816

37,161

16,148

2,703

297,326

287,646

9,680
386,517

386,517

213,537

22,238

137,036

409,329

94,109

180,276

251,341

136,553

164,908
32,437
20,692
11,745
72,330
41,669
30,761
41,240
16,148
2,753

227,586

220,912

6,674
385,824

385,824

214,828

23,142

141,587

432,170

101,263

182,317

40,334

265,218

135,895

36,893

38,886

67,972

65,872

68,762

2,839

183,340

177,765

5,575

176,254

23,757

343,172

92,892

183,363

311,660

176.609

29,487

18,648

10,839

81,361

44,210

37,151

$\begin{array}{ll}42,799 & 46,372 \\ 16,147 & 16,148\end{array}$

3,241

214,468

209,694

4,774

352,557

143,313

23,431

$135,117 \quad 140,600$

315,182

89,413

179,283

286,934

122,166

68, 762

Total Gross Domestic

Product

$2,258,897$

$2,265,369$

$2,243,660$

$2,094,174$

$2,011,072$

Source: Economic and Social Survey, Jamaica 1977. 
TABLE III -4

RATE OF GRONTH OF GROSS DOMESTIC PRODUCT BY INDUSTRIAL SECTORS AT CONSTANT PRICES

\begin{tabular}{|c|c|c|c|c|c|}
\hline Industrial Sector & 1973 & 1974 & 1975 & 1976 & 1977 \\
\hline Agriculture, Forestry and Fishing & -6.6 & 2.0 & 1.4 & 0.8 & 6.2 \\
\hline Mining and Quarrying & 12.8 & 13.5 & -23.5 & $-19 \cdot 4$ & 17.0 \\
\hline Manufacture & -1.3 & 1.7 & -0.2 & -3.3 & -5.5 \\
\hline Construction and Installation & -11.2 & -7.0 & 0.6 & -18.0 & -18.7 \\
\hline Electricity and Water & 5.6 & 0.1 & 4.1 & 2.7 & -1.4 \\
\hline $\begin{array}{l}\text { Transportation, Storage and } \\
\text { Communication }\end{array}$ & 1.8 & 10.6 & 3.3 & -4.6 & 4.1 \\
\hline Distributive Trade & -3.5 & -16.7 & 5.6 & -20.6 & $-8,2$ \\
\hline Financial Institutions & -1.1 & 9.2 & 7.6 & -8.3 & -3.7 \\
\hline Real Estate & 3.7 & 4.1 & 1.1 & 0.6 & -2.2 \\
\hline Producers of Government Services & 19.8 & 12.8 & 5.5 & 17.5 & -7.9 \\
\hline Miscellaneous Servies & -6.3 & 5.4 & -0.5 & -0.5 & -9.7 \\
\hline $\begin{array}{l}\text { Households and Private } \\
\text { Non-Profit Institutions }\end{array}$ & 13.5 & -6.7 & -8.5 & 5.4 & -3.7 \\
\hline $\begin{array}{l}\text { Total Gross Domestic Product } \\
\text { in Purchasers' Values }\end{array}$ & -0.1 & 0.3 & -1.0 & -6.7 & $-4,0$ \\
\hline
\end{tabular}

Source: Economic and Social Survey, Jamaica, 1977 
PERCENTAGE CONTRIBUTION OF GROSS DOMESTIC PRODUCT BY INDUSTRIAL SECTORS AT CONSTANT PRICES

\begin{tabular}{|c|c|c|c|c|c|}
\hline Industrial Sector & 1973 & 1974 & 1975 & 1976 & 19.77 \\
\hline Agriculture, Forestry and Fishing & 7.0 & 7.2 & 7.4 & 7.9 & 8.8 \\
\hline Mining and Quarrying & 11.6 & 13.1 & 10.1 & 8.7 & 10.7 \\
\hline Manufacture & 16.8 & 17.1 & 17.2 & 17.8 & 17.5 \\
\hline Construction and Installation & 10.2 & 9.4 & 9.6 & 8.4 & 7.1 \\
\hline Electricity and Water & 1.0 & 1.0 & 1.0 & 1.1 & 1.1 \\
\hline $\begin{array}{l}\text { Transportation, Storage and } \\
\text { Communication }\end{array}$ & 5.5 & 6.0 & 6.3 & 6.5 & 7.0 \\
\hline Distributive Trade & 21.8 & 18.1 & 19.3 & 16.4 & 15.7 \\
\hline Financial Institutions & 3.8 & 4.1 & 4.5 & 4.4 & 4.4 \\
\hline Real Estate & 7.7 & 8.0 & 8,1 & 8.8 & 8.9 \\
\hline Producers of Government Services & 9.9 & 11.1 & 11.8 & 14.9 & 14.3 \\
\hline Miscellaneous Services & 5.7 & 6.0 & 6.1 & 6.5 & 6.1 \\
\hline $\begin{array}{l}\text { Household and Private Non-Profit } \\
\text { Institutions }\end{array}$ & 1.9 & 1.8 & 1.6 & 1.9 & 1.8 \\
\hline Less Imputed Service Charges & 2.9 & 2.9 & 3.0 & 3.3 & 3.5 \\
\hline Total & 100.0 & 100.0 & 100.0 & 100.0 & 100.0 \\
\hline
\end{tabular}

Source: Economic and Social Survey - Jamaica 1977 
The manufacturing sector was the major contributor to G.D.P. in 1977 ( $17.5 \%$ ), despite a decline of 5.5 percent in output. The distributive sector declined ( -8.2 percent), government $(-7.9$ percent $)$ and miscellaneous services $(-9.6$ percent). Real growth was achieved by only three sectors in 1977; Agriculture $(+6.2 \%)$, Mining and Quarrying $(+17.0 \%)$ and Transportation, Communication and Storage $(+4.1 \%)$.

Net investments in 1977 declined by 83 percent. The decline in investment was reflected in a 18.7 percent contraction in real output of the Construction and Installation sector; following a similar decline of 18.0 percent in 1976. National Savings was also negative and external borrowings declined by 51 percent. At the same time that National Savings was negative in 1977, the financial institutions, in particular commercial banks, experienced a high degree of liquidity as bank deposits continued to increase while demand for loans declined. Aggregate saving is determined by both savers and dissavers. The sum of corporate and personal savings in 1977 totalled $\$ 37.2$ million, while government savings were negative $\$ 1564$ miliion.

\section{External Trade}

The year 1977 ended with a reduced deficit on visible trade due to the restrictions placed on the importation of non-essential items and the improved performance of the Bauxite/Alumina industry.

However, provisional trade data for the year 1978 (at exchange rates existing at December 31 , 1978) show a trade 
deficit of J\$131 million. This is a considerable deterioration compared to a deficit of J\$22.5 mil1ion for 1977.

The surge in imports for 1978 was due to increased raw material importations for manufacturers, in particular, exporters. Provisional data on External Trade for January to December 1977 and 1978 is compared in Table III-6.

\begin{tabular}{|c|c|c|c|c|}
\hline \multicolumn{5}{|c|}{ External Trade For 1977 and 1978} \\
\hline & $\begin{array}{c}\text { Jan-Dec. } \\
1977 \\
\end{array}$ & $\begin{array}{c}\text { Jan-Dec. } \\
1978 \\
\end{array}$ & Change & : Change \\
\hline Exports (f.o.b.) & 707,312 & $1,094,838$ & $+387,526$ & +54.8 \\
\hline Imports (c.i.f.) & 781,639 & $1,256,952$ & $+475,213$ & +60.8 \\
\hline Trade Balance & $-74,327$ & $-162,014$ & $-87,687$ & -117.9 \\
\hline
\end{tabular}

At Exchange Rate Existing at Dec. 1978 Jan-Dec. Jan-Dec.

$1977 \quad 1978$ Change

Exports (f,o.b.)

$1,243,399$

$1,261,330$

$+17,931$

$+14.4$

Imports (c.i.f.)

$\frac{1,265,876}{-22,477} \quad \frac{1,392,634}{-131,304}$

$+126,758+10.0$

$-1.08,827 \quad-484.1$

Source: Bank of Jamaica, March 1979

The year 1978 also saw further devaluations and in May 1978, a unified rate of exchange was established.

Table III- 7 sets out the various exchange rates over the period April 1973 - August 1978. 


\section{TABLE III - 7}

\section{Rate of Exchange}

1973 - April 21, 1977

Apri1 22, 1977 - Oct. 24, 1977

Oct. $25,1977-\operatorname{Jan}, 13,1978$

Jan.18, 1978 - April, 1978

May 9, 1978

June 8, 1978

July 14,1978

August 10, 1978
$J \$ 1.00=$ US $\$ 1.10$

Basic Rate

$J \$ 1.00=0 S \$ 1.10$

Special Rate
J\$I.25 $=$ US\$I.00

$\mathrm{J} \$ 1.00=$ US\$1.10 J $\$ 1.28=$ US $\$ 1.00$

$J \$ 1.05=$ US\$1.00 J $\$ 1.35-$ US $\$ 1.00$

Unified Exchange Rate Established $\mathrm{J} \$ 1.55=\mathrm{US} \$ 1.00$

$\mathrm{J} \$ 1.57=\mathrm{US} \$ 1.00$

$\mathrm{J} \$ 1.60=$ US $\$ 1.00$

$J \$ 1.65=\mathrm{US} \$ 1.00$

In June, 1979 , the exchange rate was J\$1.78 - US\$1.00 or US\$0.57-J\$1.00.

The Balance of Visible Trade for the years 1938-1978 is shown in Table III-8. (see following page) 
TABLE III -8

TOTAL EXTERNAL TRADE $1938,1948,1958-1977$, BY QUARTERS 1975-1977

BY MONTH 1977 (MIXED AND BASIC RATES)

\begin{tabular}{|c|c|c|c|c|c|}
\hline \multirow[b]{2}{*}{ Period } & \multirow{2}{*}{$\begin{array}{l}\text { Balance of } \\
\text { Visible } \\
\text { Trade } \\
\end{array}$} & \multirow[b]{2}{*}{$\begin{array}{l}\text { Imports } \\
(\mathrm{C} . \mathrm{I} . \mathrm{F} .)\end{array}$} & \multicolumn{3}{|c|}{ EXPORTS (F.O.B.) } \\
\hline & & & Total & $\begin{array}{l}\text { Domestic } \\
\text { Exports }\end{array}$ & Re-Exports \\
\hline 1938 & $-\quad 2,905$ & 12,970 & 10,065 & 9,852 & 213 \\
\hline 1948 & $-16,587$ & 39,362 & 22,775 & 22,301 & 474 \\
\hline 1958 & $-34,071$ & 129,293 & 95,222 & 93,512 & 1,710 \\
\hline 1959 & $-45,059$ & 137,292 & 92,233 & 90,537 & 1,696 \\
\hline 1960 & $-41,672$ & 155,002 & 113,330 & 111,523 & 1,807 \\
\hline 1961 & $-27,677$ & 150,791 & 123,114 & 121,264 & 1,850 \\
\hline 1962 & $-29,514$ & 159,202 & 129,688 & 124,469 & 5,219 \\
\hline 1963 & $-16,855$ & 161,085 & 144,230 & 140,368 & 3,862 \\
\hline 1964 & $-52,199$ & 206,657 & 154,458 & 151,151 & 3,307 \\
\hline 1965 & $-53,327$ & 206,470 & 153,143 & 149,874 & 3,269 \\
\hline 1966 & $-70,833$ & 233,706 & 162,873 & 160,217 & 2,656 \\
\hline 1967 & $-89,265$ & 252,579 & 163,314 & 160,745 & 2,569 \\
\hline 1968 & $-137,343$ & 320,346 & 183,003 & 179,495 & 3,508 \\
\hline 1969 & $-151,521$ & 363,301 & 211,780 & 206,100 & 5,680 \\
\hline 1970 & $-153,007$ & 437,839 & 284,832 & 279,116 & 5,716 \\
\hline 1971 & $-177,050$ & 459,754 & 282,704 & 275,203 & 7,501 \\
\hline 1972 & $-189,110$ & 489,256 & 300,146 & 292,277 & 7,869 \\
\hline 1973 & $-260,515$ & 615,123 & 354,608 & 347,841 & 6,767 \\
\hline 1974 & $-208,700$ & 850,781 & 642,081 & 630,769 & 11,312 \\
\hline 1975 & $-247,267$ & $1,021,412$ & 774,145 & 760,889 & 13,256 \\
\hline $\begin{array}{l}1976 \\
1977 \text { Mixed }\end{array}$ & $-254,790$ & 829,785 & 574,995 & 560,872 & 14,123 \\
\hline Rate) & $-74,326$ & 781,639 & 707,313 & 793,411 & 13,902 \\
\hline 1977 (Basic & & & & & \\
\hline 1978 Ratel & $\begin{array}{l}-12,085 \\
-181,727\end{array}$ & $\begin{array}{r}678,951 \\
278,052\end{array}$ & $\begin{array}{r}666,865 \\
06,325\end{array}$ & $\begin{array}{l}655,267 \\
\text { N/A }\end{array}$ & 11,598 \\
\hline & $-101,128$ & $1,260,002$ & $1,020,320$ & & \\
\hline
\end{tabular}

Source: External Trade 1977; Department of Statistics 
IMPORT AND EXPORT VOLUNE INDICES

1969 - 1977

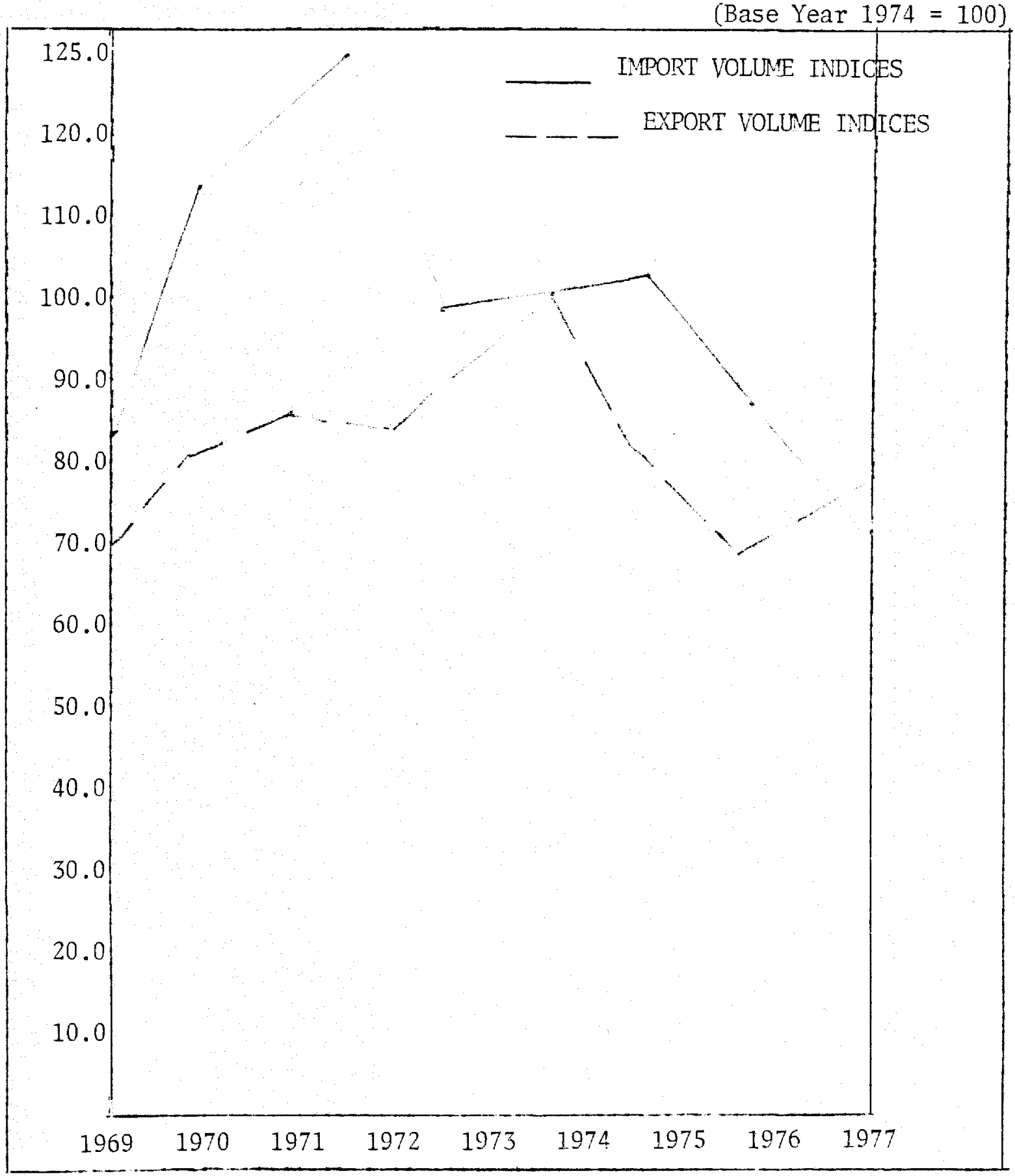

Source: Department of Statistics, Jamaica 
For the years 1973-1978, not only has Net Foreign Debt increased, but Jamaica's Net Foreign Reserves has taken an increasingly negative plunge. This is shown in Table I I I -9 .

TABLE III-9

FOREIGN DEBT AND NET EXCHANGE RESERVES J\$'000

\begin{tabular}{|c|c|c|c|}
\hline $\begin{array}{l}\text { End of } \\
\text { Period }\end{array}$ & $\begin{array}{l}\text { Total } \\
\text { Foreign } \\
\text { Debt }\end{array}$ & $\begin{array}{l}\text { Net } \\
\text { Foreign } \\
\text { Reserves }\end{array}$ & $\begin{array}{l}\text { Net Foreign } \\
\text { Reserves as } \\
\text { a } \% \text { of Net } \\
\text { Foreign Debt }\end{array}$ \\
\hline 1973 & 133,070 & 76,100 & 57.2 \\
\hline 1974 & 243,371 & 130,200 & 53.5 \\
\hline 1975 & 356,684 & 58,500 & 16.4 \\
\hline 1976 & 421,521 & $-181,400$ & - \\
\hline 1977 & 452,457 & $-196,000$ & -- \\
\hline 1978 & $1,128,397$ & $-447,400$ & $\cdots$ \\
\hline Jan., 1979 & $1,179,441$ & $-413,600$ & $\cdots$ \\
\hline Feb., 1979 & Not Available & $-469,300$ & - \\
\hline Mar., 1979 & Not Available & $-405,100$ & - \\
\hline
\end{tabular}

Source: Bank of Jamaica

Imports

Over the four year period 1973-1976, the overall import price index for Jamaica grew by 139 percent $^{1}$, and the economy's real capacity to import, calculated by dividing export earnings by the import price index, declined.

${ }^{1}$ Five Year Development PIan Jamaica 1978-82. op.cit., p. 6. 
Table III-10 gives annual changes in imports for the period $1960-1978$

TABLE III- 10

ANNUL CHANGES IN TOTAL IMPORTS: 1960-1978

\begin{tabular}{|c|c|c|c|}
\hline $\begin{array}{l}\text { Period } \\
\text { of Trade }\end{array}$ & $\begin{array}{l}\text { Total } \\
\text { Imports } \\
\$ 1000 \\
\end{array}$ & $\begin{array}{l}\text { Annual Changes } \\
\text { in Imports } \\
\text { \$:000 }\end{array}$ & $\begin{array}{l}\text { Annual } \\
\text { Percentage } \\
\text { Change } \\
\end{array}$ \\
\hline 1960 & 155,002 & $-\infty$ & - - \\
\hline 1961 & 150,791 & $-4,211$ & -2.7 \\
\hline 1962 & 159,202 & 8,411 & 5.6 \\
\hline 1963 & 161,085 & 1,883 & 1.2 \\
\hline 1964 & 206,657 & 45,572 & 28.3 \\
\hline 1965 & 206,470 & -187 & 0.0 \\
\hline 1966 & 233,706 & 27,236 & 13.2 \\
\hline 1967 & 252,579 & 18,873 & 8.1 \\
\hline 1968 & 320,346 & 67,767 & 26.8 \\
\hline 1969 & 363,301 & 42,955 & 13.4 \\
\hline 1970 & 437,839 & 74,538 & 20,5 \\
\hline 1971 & 459,754 & 21,915 & 5.0 \\
\hline $197 \overline{2}$ & 489,256 & 29,502 & 6.4 \\
\hline 1975 & 615,123 & 125,867 & 25.7 \\
\hline 1974 & 850,781 & 246,282 & 40.7 \\
\hline 1975 & $1,021,412$ & 170,631 & 20.1 \\
\hline 1976 & 829,785 & $-191,627$ & -18.8 \\
\hline 1977 (Mixed Rate) & 781,639 & $-48,146$ & $-5,8$ \\
\hline 1978 & $1,256,852$ & 475,213 & 60.8 \\
\hline
\end{tabular}

Source: External Trade

The value of consumer goods imported declined from 33 percent to 13 percent of total imports between 1972-1977. The target, according to the most recent five year Development Plan, is to have consumer goods decline to 6 percent by 1982.1

${ }^{1}$ Five Year Development Plan, Jamaica 1978-82, op.cit. 
Raw materials represented $65.2 \%$ of total imports in 1977. Fuel imports accounted for $28.5 \%$ of imports, due to increase in the price of oil and capital goods represented $22.0 \%$ of total imports in 1977 .

\section{TABLE III- 11}

IMPORTS BY ECONOMIC FUNCTION OR END-USE: 1975-1977

\begin{tabular}{|c|c|c|c|c|c|c|}
\hline \multirow{2}{*}{ Category } & \multicolumn{2}{|c|}{1975} & \multicolumn{2}{|c|}{1976} & \multicolumn{2}{|c|}{1977 (Mixed Rate) } \\
\hline & $\$ 000$ & $\frac{3}{6}$ & $\$ 1000$ & $\frac{6}{6}$ & $\$ 1000$ & $\frac{0}{3}$ \\
\hline ALL CATEGORIES & $1,021,412$ & 100,0 & 829,785 & 100.0 & 781,638 & 100.0 \\
\hline Consumer Goods & 212,642 & 20.8 & 149,499 & 18.0 & 99,876 & 12.8 \\
\hline Food & 118,101 & 11.5 & 80,024 & 9.6 & 52,317 & 6.7 \\
\hline Other Non-Durable & 43,825 & 4.3 & 32,497 & 3.9 & 24,717 & 3.2 \\
\hline Durable & 50,716 & 5.0 & 36,978 & 4.5 & 22,942 & 2.9 \\
\hline Raw Materials & 494,321 & 48.4 & 467,643 & 56.4 & 510,039 & 65.2 \\
\hline Fuels & 195,513 & 19.1 & 185,008 & 22.3 & 223,174 & 28.5 \\
\hline Other & 298,808 & 29.3 & 282,635 & 34.1 & 286,865 & 36.7 \\
\hline Capital Goods & 314,449 & 30.8 & 212,643 & 25.6 & 171,624 & 22.0 \\
\hline Construction & & & & & & \\
\hline Materials & 89,227 & 8.7 & 65,234 & 7.9 & 70,297 & 9.0 \\
\hline $\begin{array}{l}\text { Transport Equip- } \\
\text { ment }\end{array}$ & 78,708 & 7.7 & 24,226 & 2.9 & 15,333 & 2.0 \\
\hline Other Machinery & & & & & & \\
\hline \& Equipment & 137,420 & 13.5 & 108,867 & 13.1 & 72,615 & 9.3 \\
\hline Other Capital & 9,130 & 0.9 & 14,316 & 1.7 & 13,379 & 1.7 \\
\hline
\end{tabular}

Source: Department of Statistics, Jamaica 
TABLE III-12

RAW MATERIAL IMPORTS $1975-1977$

\begin{tabular}{|c|c|c|c|c|c|c|}
\hline \multirow{2}{*}{ Category } & \multicolumn{2}{|c|}{1975} & \multicolumn{2}{|c|}{1976} & \multicolumn{2}{|c|}{1977 (Mixed Rate) } \\
\hline & $\$ 000$ &.$\%$ & $\$ 000$ & $\frac{6}{3}$ & $\$ 000$ & $\frac{\pi}{3}$ \\
\hline ALL CATEGORIES & 494,321 & 100.0 & 467,643 & 100.0 & 510,039 & 100.0 \\
\hline Fuels & 195,513 & 39.6 & 185,005 & 39.6 & 223,174 & 43.8 \\
\hline Food and Tobacco & 62,993 & 12.7 & 84,940 & 18.2 & 69,357 & 13.6 \\
\hline Chemicals & 89,584 & 18.1 & 67,740 & 14.5 & 82,266 & 16.1 \\
\hline $\begin{array}{l}\text { Paper \& Paperboard } \\
\text { Ferrous and Non- }\end{array}$ & 25,320 & 5.1 & 21,045 & 4.5 & 20,219 & 4.0 \\
\hline Ferrous Metals & 8,185 & 1.7 & 4,069 & 0.8 & 7,301 & 1.4 \\
\hline Textiles & 36,717 & 7.4 & 34,015 & 7.3 & 31,591 & 6.2 \\
\hline $\begin{array}{l}\text { Non-Metallic Minerals } \\
\text { Manufactures of }\end{array}$ & 8,855 & 1.8 & 7,797 & 1.7 & 5,755 & 1.1 \\
\hline $\begin{array}{l}\text { Metals } \\
\text { Crude Materials, }\end{array}$ & 12,422 & 2.5 & 9,308 & 2.0 & 9,617 & 1.9 \\
\hline Inedible Except & & & & & & \\
\hline Fue1s & 14,512 & 2.9 & 14,576 & 3.1 & 24,838 & 4.9 \\
\hline Animal Feeds & 2,760 & 0.6 & 2,897 & 0.6 & 3,679 & 0.7 \\
\hline Other & 37,460 & 7.6 & 36,251 & 7.7 & 32,242 & 6.3 \\
\hline
\end{tabular}

Source: External Trade 1977, Jamaica

In 1978 most categories of imports recorded increases. Manufactured goods, food, machinery and transport equipment, and miscellanious manufactured goods. 
TABLE III- 13

J\$ 000 - Value of Imports - at Exchange Rate Existing Dec. 31, 1978

\begin{tabular}{|c|c|c|c|c|}
\hline S.T.T.C. & $\begin{array}{l}\text { Jan. -Dec. } \\
1977\end{array}$ & $\begin{array}{l}\text { Jan. -Dec. } \\
1978\end{array}$ & Change & : Change \\
\hline 0. Food & 214,784 & 270,826 & $+56,042$ & +26.1 \\
\hline 1. Beverage and Tobacco & 9,301 & 11,352 & $+2,051$ & 22.1 \\
\hline 2. Crude Materials & 62,008 & 57,778 & $-4,230$ & -6.8 \\
\hline 3. Mineral Fuels & 387,999 & 340,871 & $-47,128$ & -12.1 \\
\hline $\begin{array}{l}\text { 4. Animal \& Vegetable } \\
\text { Oil \& Fats }\end{array}$ & 16,088 & 16,589 & +501 & +3.1 \\
\hline 5. Chemicals & 153,910 & 166,955 & $+13,045$ & +8.5 \\
\hline 6. Manufactured Goods & 222,610 & 292,731 & $+70,121$ & +31.5 \\
\hline $\begin{array}{l}\text { 7. Machinery \& Transport } \\
\text { Equipment }\end{array}$ & 143,717 & 167,890 & $+24,173$ & +16.8 \\
\hline $\begin{array}{l}\text { 8. Miscellaneous Manufac- } \\
\text { tured Goods }\end{array}$ & 49,613 & 60,686 & $+11,073$ & +22.3 \\
\hline \multirow[t]{2}{*}{$\begin{array}{l}\text { 9. Miscellaneous Conmodi- } \\
\text { ties }\end{array}$} & 5,846 & 6,956 & $+1,110$ & +19.0 \\
\hline & $1,265,876$ & $1,392,634$ & $+126,758$ & +10.0 \\
\hline
\end{tabular}

Source: Bank of Jamaica, March, 1979,

Domestic Exports

Export earnings were estimated at $\$ 707.3$ million in 1977. ${ }^{1}$ The following Table III-14 give total Domestic Exports for 1960-1977 and the percentage change. Table III15 gives exports by product type for 1975-1977. 
TABLE III-14

DOMESTIC EXPORTS 1960-1977

\begin{tabular}{lccc}
\hline $\begin{array}{l}\text { Period } \\
\text { of Trade }\end{array}$ & $\begin{array}{l}\text { Total } \\
\text { Domestic } \\
\text { Exports }\end{array}$ & $\begin{array}{l}\text { Annual } \\
\text { Change } \\
\text { in Value }\end{array}$ & $\begin{array}{l}\text { Annual } \\
\text { Percentage } \\
\text { Change }\end{array}$ \\
\hline 1960 & 111,523 & -- & -- \\
1961 & 121,264 & 9,714 & 8.7 \\
1962 & 124,469 & 3,205 & 2.6 \\
1963 & 140,368 & 15,899 & 12.8 \\
1964 & 151,151 & 10,783 & 7.7 \\
1965 & 149,874 & $-1,277$ & -0.8 \\
1966 & 160,217 & 10,343 & 6.9 \\
1967 & 160,745 & 528 & 0.3 \\
1968 & 179,495 & 18,750 & 11.7 \\
1969 & 206,100 & 26,605 & 14.8 \\
1970 & 279,116 & 73,016 & 35.4 \\
1971 & 275,203 & $-3,913$ & -1.4 \\
1972 & 292,277 & 17,074 & 6.2 \\
1973 & 347,841 & 55,564 & 19.0 \\
1974 & 630,769 & 282,928 & 81.3 \\
1975 & 760,889 & 130,120 & 20.6 \\
1976 & 560,872 & $-200,017$ & -26.3 \\
1977 (Mixed & & & 26.1 \\
1978 & 707,312 & 146,440 & 54.8 \\
\hline & $1,094,838$ & 387,526 & \\
\hline
\end{tabular}

* Revised - Bank of Jamaica, March 1979

Source: External Trade, Jamaica 1977 
A breakdown of total Domestic Exports by value and percentage is shown in Table III-15. Food exports made up $16.6 \%$ of total Domestic Exports in 1977, falling from $23.5 \%$ in 1975. The volume of both sugar and bananas fe11, but the value in Jamaican dollars increased positively, due to the effects of the devalued Jamaican doliar as against the U.S. dollar standard on the world market.

TABLE III - 15

Value and Percentage Distribution of Total Domestic Exports 1975 to 1977

\begin{tabular}{|c|c|c|c|c|c|c|}
\hline \multirow{2}{*}{ S.I.T.C. Sections } & \multicolumn{2}{|c|}{1975} & \multicolumn{2}{|c|}{1976} & \multicolumn{2}{|c|}{1977} \\
\hline & $\$ 000$ & $\%$ & $\$ 1000$ & $\%$ & $\$ 1000$ & $\%$ \\
\hline ALL SECTIONS & 760,889 & 100.0 & 560,872 & 100.0 & 693,412 & 100.0 \\
\hline 0. Food & 179,096 & 23.5 & 94,703 & 16.9 & 114,583 & 16.6 \\
\hline 1. Beverage and Tobacco & 18,782 & 2.5 & 21,366 & 3.8 & 25,699 & 3.7 \\
\hline $\begin{array}{l}\text { 2. Crude Materials, In- } \\
\text { edible Except Fuels }\end{array}$ & 518,042 & 68.1 & 392,251 & 69.9 & 493,915 & 71.2 \\
\hline $\begin{array}{l}\text { 3. Mineral Fuels, Lubri- } \\
\text { cants and Related } \\
\text { Materials }\end{array}$ & 10,500 & 1.4 & 14,929 & 2.7 & 15,827 & 2.3 \\
\hline $\begin{array}{l}\text { 4. Animal and Vegetable } \\
\text { Oils and Fats }\end{array}$ & 71 & * & 27 & * & 222 & $*$ \\
\hline 5. Chemicals & 11,338 & 1.5 & 12,514 & 2.2 & 14,549 & 2.1 \\
\hline $\begin{array}{l}\text { 6. Manufactured Articles } \\
\text { Classified Chiefly } \\
\text { by Materials }\end{array}$ & 10,682 & 1.4 & 10,193 & 1.9 & 11,912 & 1.7 \\
\hline $\begin{array}{l}\text { 7. Machinery and Trans- } \\
\text { port Equipment }\end{array}$ & 2,420 & 0.3 & 3,420 & 0.6 & 4,180 & 0.6 \\
\hline $\begin{array}{l}\text { 8. Miscellaneous Manufac- } \\
\text { tured Articles }\end{array}$ & 9,956 & 1.3 & 11,464 & 2.0 & 12,494 & 1.8 \\
\hline $\begin{array}{l}\text { 9. Miscellaneous Trans- } \\
\text { actions and Commo- } \\
\text { dities }\end{array}$ & 2 & $*$ & 5 & $*$ & 31 & * \\
\hline
\end{tabular}

* Indicates less than $0.05 \%$

Source: External Trade, Janaica, 1977 
1978 saw the major export commodities - bauxite,

alumina, sugar and bananas accounting for 83.0 percent of total imports. This is slightly lower than 83.5 percent recorded for 1977. The value of bauxite exports was $10 w e r$ in 1978 but this was due to a higher level of conversion into alumina. Details of the four major export items are compared for years 1977 and 1978 in Table III-16.

\section{TABLE III- 16}

Major Exports - at Exchange Rate Existing December 31,1978 $J \$ 000$

\begin{tabular}{|c|c|c|c|c|}
\hline Value (JS'000) & $\begin{array}{c}\text { Jan-Dec. } \\
1977 \\
\end{array}$ & $\begin{array}{c}\text { Jan-Dec. } \\
1978 \\
\end{array}$ & Change & $\%$ Change \\
\hline Bauxite & 272,017 & 257,254 & $-14,763$ & -5.4 \\
\hline Alumina & 640,038 & 662,874 & $+22,836$ & +3.6 \\
\hline Sugar & 100,870 & 98,562 & $-2,308$ & -2.3 \\
\hline Bananas & 24,859 & 28,512 & $+3,653$ & +14.7 \\
\hline & $1,037,784$ & $1,047,202$ & 9,418 & $\div 0.9$ \\
\hline \multicolumn{5}{|c|}{ Volume (000 Metric Tons) } \\
\hline Bauxite & 6,355 & 6,472 & 117 & +1.8 \\
\hline Alumina & 2,034 & 2,140 & $+\quad 106$ & +5.2 \\
\hline Sugar & 217 & 199 & 18 & -8.3 \\
\hline Eananas & 76 & 76 & $*$ & $*$ \\
\hline
\end{tabular}

Source: Bank of Jamaica, March 1976 
Table III-17 shows the value of exports according to the Standard International Trade Classification compared for 1977 and 1978 .

TABLE III-17

VALUE OF EXPORTS - At Exchange Rate Existing December 31, 1978. $\mathrm{J} \$ 000$

S.I.T.C. Sections

0. Food

1. Beverage and Tabacco

2. Crude Materials

3. Mineral Fuels

4. Animals and Vegetable Oils and Fats

5. Chemicals

6. Manufactured Goods

7. Machinery and Transport Equipment

8. Miscellaneous Manufactured Goods

9. Miscellaneous Comnodities

Jan-Dec.

1977

177,346

38,596

919,351

24,294

332

21,884

18,555

22,330

20,068
Jan-Dec. 1978

171,379

35,425

929,919

37,139
Charge : Charge

$-5,967-3.4$
$-3,171$

$-3,171-8.2$

$+10,568+1.1$

$+12,845+52,9$ dities

\begin{tabular}{|c|c|c|c|}
\hline 643 & 395 & $-\quad 248$ & -38.6 \\
\hline $1,243,399$ & $1,261,330$ & $+17,931$ & +1.4 \\
\hline
\end{tabular}

Source: Bank of Jamaica, March 1979 
The U.S.A. continues to be both the major supplier of imports to Jamaica and principal purchaser of Jamaican Exports as depicted in Tables III-13 and Tables 19.

TABLE III -18

VALUE OF IMPORTS FROM PRINCIPAL COUNTRIES 1975 - 1977

\begin{tabular}{|c|c|c|c|c|c|c|}
\hline \multirow{2}{*}{ Countries } & \multicolumn{2}{|c|}{1975} & \multicolumn{2}{|c|}{1976} & \multicolumn{2}{|c|}{1977} \\
\hline & $\$ 1000$ & $\%$ & $\$ 1000$ & $\frac{9}{0}$ & $\$ 000$ & $\%$ \\
\hline ALL COUNTRIES & $1,021,412$ & 100.0 & 829,785 & 100,0 & 781,639 & 100.0 \\
\hline United States of America & 382,311 & 37.8 & 308,332 & 37.2 & 281,319 & 36.0 \\
\hline United Kingdom & 133,907 & 13.1 & 90,331 & 10.9 & 76,114 & 9.7 \\
\hline Canada & 49,558 & 4.9 & 48,880 & 5.9 & 43,555 & 5.6 \\
\hline Austra1ia (incl. Tasmania) & 8,037 & 0.8 & 6,282 & 0.8 & 6,571 & 0.8 \\
\hline New Zealand & 15,232 & 1.5 & 17,927 & 2.2 & 10,221 & 1.3 \\
\hline Trinidad and Tobago & 49,342 & 4.8 & 34,201 & 4.1 & 20,106 & 2.6 \\
\hline Guyana & 28,213 & 2.8 & 16,629 & 2.0 & 12,628 & 1.6 \\
\hline West Germany & 31,441 & 3.1 & 25,852 & 3.1 & 20,907 & 2.7 \\
\hline France & 9,027 & 0.9 & 6,118 & 0.7 & 7,299 & 0.9 \\
\hline Japan & 38,566 & 3.8 & 26,335 & 3.2 & 17,571 & 2.2 \\
\hline Netherlands - Holland & 11,185 & 1.1 & 6,999 & 0.8 & 7,490 & 1.0 \\
\hline Netherlands - Antilles & 25,439 & 2.5 & 46,788 & 5,6 & 85,392 & 10.9 \\
\hline Venezuela & 140,166 & 13.7 & 115,880 & 13.9 & 125,521 & 16.1 \\
\hline Others & 98,988 & 9.7 & 79,231 & 9.6 & 66,945 & 8.6 \\
\hline
\end{tabular}


TABLE III - 19

VALUE OF DOMESTIC EXPORTS TO PRINCIPAL COUNTRIES $1975-1977$

\begin{tabular}{|c|c|c|c|c|c|c|}
\hline \multirow{2}{*}{ Countries } & \multicolumn{2}{|c|}{1975} & \multicolumn{2}{|c|}{1976} & \multicolumn{2}{|c|}{1977} \\
\hline & $\$ 000$ & $\frac{8}{6}$ & 3000 & 6 & $\$ 000$ & $\frac{9}{6}$ \\
\hline ALL COUNTRIES & 727,312 & 100.0 & 560,872 & 100.0 & 693,411 & 100.0 \\
\hline United States of America & 270,581 & 37.2 & 231,850 & 41.2 & 302,919 & 43.7 \\
\hline United Kingdom & 169,696 & 23.3 & 98,776 & 17.6 & 138,165 & 19.9 \\
\hline Canada & 21,469 & 2.9 & 25,850 & 4.6 & 56,393 & 8.1 \\
\hline Trinidad and Tobago & 13,664 & 1.9 & 18,820 & 3.4 & 23,876 & 3.4 \\
\hline Guyana & 6,791 & 0.9 & 7,767 & 1.4 & 5,140 & 0.8 \\
\hline Norway & 87,613 & 12.2 & 73,793 & 13.2 & 78,212 & 11,3 \\
\hline Sweden & 15,673 & 2.2 & 26,250 & 4.7 & 14,262 & 2.1 \\
\hline West Germany & 2,335 & 0.3 & 3,365 & 0.6 & 3,426 & 0.5 \\
\hline Barbados & 4,645 & 0.6 & 6,028 & 1.1 & 7,979 & 1.1 \\
\hline Ghana & -- & $\cdots$ & - & -- & 12,571 & 1.8 \\
\hline Iran & 35,744 & 4.9 & - & -- & - & - \\
\hline Others & 99,101 & 13.6 & 68,373 & 12.2 & 50,468 & 7.3 \\
\hline
\end{tabular}

Source: Extemal Trade Jamaica 1977

Consumer Prices

On a point-to-point basis, the "A11-Items" index for Jamaica increased by 49.4 percent in 1978. This is considerable when compared to an increase of 14.1 percent in 1977 . This has been due to the effects of devaluation, in particular, the abolition of the dual exchange rate, monthly devaluations, new tax measures and relaxed price controls."

Jamaica's economy is heavily dependent upon six industrial sectors - agriculture, mining, manufacturing,

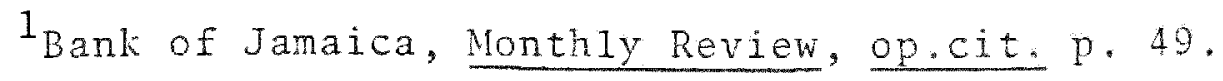


construction, distribution and miscellaneous services, including tourism. These sectors, and public administration are all "basic", or "generating" sectors. It is they which determine the level of production, employment and income for the entire economy in general.

Agriculture is export-oriented, almost all of mining is exported, whereas 85 percent of manufacturing output is consumed locally. ${ }^{1}$ The level of construction and public administration activity is influenced by overall economic conditions. In an export-oriented economy like Jamaica, domestic production and developmental achievements is determined by external demand forces of which Jamaica has very 1 ittle control.

\section{Agriculture}

Jamaica has a total 1 and area of 4,243 square miles, that is, 2,715,000 acres, half of which is at least 1,000 feet above sea level. A land use distribution table is given on the following page. 
TABLE III - 20

\begin{tabular}{lrc}
\hline Type of Land & Acres & Percentage \\
\hline Total & $2,715,000$ & 100.0 \\
Forestry & 655,000 & 24.0 \\
Other Woodland & 538,000 & 19.7 \\
Agricul ture, incl. pasture & $1,258,000$ & 46.4 \\
Natural range and grassland & 103,000 & 3.8 \\
Swamp & 50,000 & 1.8 \\
Mining & 7,000 & 0.4 \\
Urban & 100,000 & 3.7 \\
Barren & 4,000 & 0.1 \\
\hline
\end{tabular}

Source: United Nations Development Progranme, Town Planning Department.

The latest agricultural census of 1968 show that agriculture (including commercial forestry) occupied about 1.5 million acres of land, that is, 55 percent of Jamaica's total land area. According to the Census of Agriculture 1968-1969, in 1968 there were on $1 y 994$ farms over 100 acres, less than 1.0 percent of al1 farms, yet these farms accounted for $55 \%$ of all farm acreage. In 1968 the national average farm size was about 8 acres, small farms under 25 acres made up 98 percent of all farms, yet covered only 37 percent of farm acreage. Medium-size farms between 25 and 200 acres account for only 12 percent of total farm acreage.

The distribution of farm lands by major use is shown in Table III-21. 
TABLE III-21

DISTRIBUTION OF LAND IN FARM BY MAJOR TYPES OF USE, 1968

\begin{tabular}{lrr}
\hline Type of Use & Acreage & of. Total \\
\hline Sugar Cane & 167,000 & 11.2 \\
Bananas & 84,000 & 5.6 \\
Coconuts & 100,000 & 6.7 \\
Citrus & 25,000 & 1.7 \\
Cocoa & 27,000 & 1.8 \\
Coffee & 15,000 & 1.0 \\
Pimento & 24,000 & 1.6 \\
Tobacco & 1,900 & 0.1 \\
Other tree crops & 1,000 & 0.1 \\
Domestic food crops & 91,000 & 6.1 \\
Commercial forests & 16,000 & 1.1 \\
Improved pasture & 250,000 & 16.6 \\
Natural range (grassland) & 138,400 & 9.2 \\
Other lands suitable for & & \\
$\quad$ agriculture & 139,000 & 9.2 \\
Remainder* & 420,000 & 28.0 \\
Total & $1,500,000$ & 100.0
\end{tabular}

*Remainder: Includes forests, woodlands, swamps, etc.

Source: Five-Year Development P1an Jamaica 1978-82

This pattern of 1 and use did not follow any specific plan aimed at optimum use of the limited land resources. The result is the present haphazard land use development.

Most of the crops in the table are grown in a mixed manner. Sugar, the major export crop occupies most of the alluvial coastal plains and interior valleys and is grown usually in a pure stand. Bananas, the second major export corp, 
is grown both in a pure and mixed stand on the coast and interiors. Sugar and bananas occupy the best and most fertile lands, over 252,000 acres, 21 percent of the land classified as suitable for agricultural corps. ${ }^{1}$

However, the value of sugar and bananas exported in 1977 amounted to only J\$85 million which was insufficient to cover the imports of consumer goods including food imports which totalled J\$100 million in that same year. Food imports alone, although declining due to the import restructions adopted, cost the country J\$52 million.

In 1938 , the agricultural sector contributed 36 percent to Jamaica's gross domestic product, ${ }^{2}$ in 1973 this fell to 7 percent and in 1977 it accounted for 8.8 percent in real terms. Domestic agriculture in 1977 improved from J\$68.5 million to J\$81.4 million livestock production also increased by 8.3 percent; forestry and logging by 14 percent over 1976 level,

The volume of agricultural production for the period 1973-1977 is shown in Table III-22,

${ }^{1}$ Five-Year Development Plan, 1978-82, op.cit.

${ }^{2}$ Adam Kaper, op.cit., p. 21 
TABLE III-22

VOLURE OF AGRICULTURAL PRODUCTION: 1973-1977

\begin{tabular}{|c|c|c|c|c|c|c|}
\hline Item & 1973 & 1974 & 1975 & 1976 & 1977 & $\begin{array}{l}: \text { Change } \\
1973-1977\end{array}$ \\
\hline Sugar Cane ('000 tons) & 3,584 & 3,785 & 3,524 & 3,571 & 3,177 & -11.4 \\
\hline $\begin{array}{l}\text { Sugar ('000 tons } \\
\text { Commercial) }\end{array}$ & 326. & 367 & 355 & 357 & 290 & -11.0 \\
\hline Bananas* ('000 tons) & 108 & 72 & 68 & 77 & 80 & -26.0 \\
\hline Citrus*: ('000 boxes) & 1,062 & 1,007 & 1,028 & 946 & 666 & -37.3 \\
\hline Pimento (tons) & 1,890 & 3,949 & 2,151 & 4,181 & 1,989 & +5.2 \\
\hline Cocoa (tons) & 2,071 & 1,593 & 1,771 & 1,573 & 1,614 & -22.1 \\
\hline Coffee** ('000 boxes) & 308 & 240 & 381 & 230 & 311 & +1.0 \\
\hline Ginger (short tons) & 749 & 857 & 930 & 995 & 423 & -44.0 \\
\hline $\begin{array}{l}\text { Rum ('000 proof } \\
\text { gailons) }\end{array}$ & 5,100 & 5,735 & 6,455 & 4,475 & 5,005 & -2.0 \\
\hline Mollasses (tons) & 129 & 121 & 120 & 118 & 117 & -9.3 \\
\hline Copra (short tons) & 14,608 & 8,901 & 6,308 & 5,624 & 3,406 & $-76,7$ \\
\hline Meat (million lbs.) & 97 & 89 & 103 & 102 & 111 & +14.4 \\
\hline Fish (million 1bs.) & 38 & 36 & 36 & 36 & 37 & -2.6 \\
\hline Eggs (million) & 136 & 139 & 147 & 162 & 152 & +11.8 \\
\hline Milk (million quarts) & 41 & 43 & 43 & 42 & 41 & -- \\
\hline $\begin{array}{l}\text { Root Crops } \\
\text { pounds) }\end{array}$ & 403 & 443 & 460 & 408 & 517 & +28.3 \\
\hline $\begin{array}{l}\text { Vegetables*** (million } \\
\text { pounds) }\end{array}$ & 205 & 215 & 203 & 223 & 276 & +34.6 \\
\hline
\end{tabular}

*Exports

*Deliveries to Packaging and Processing Plants $* *$ Selected items

Note: Production figures for citrus, cocoa, pimento, sugar cane, rum and coffee are for the crop year.

Source: Economic and Social Survey - Jamaica 1977 
Between 1973 and 1977 output of agricultural crops have been drastically reduced; in particular for the major export earners, sugar, bananas, citrus, cocoa, ginger and copra. Increases were only registered for root crops, vegetables, eggs and meat for domestic consumption.

In general there has been a decline in the total acreage of sugar cane reaped. Sugar cane acreage reaped by estates have been reducing while the acreage reaped by farmers have been increasing. Table III-23 shows this.

TABLE III -23

SUGAR CANE ACREAGE REAPED AND TONNAGE PER ACRE: 1972-1977

\begin{tabular}{l|l:l:l:l}
\hline & Crop Year & Estate & Farmers & Total \\
\hline \multirow{4}{*}{ Acreage Reaped } & $1972-73$ & 59,755 & 78,140 & 133,895 \\
& $1973-74$ & 65,176 & 78,410 & 143,586 \\
& $1975-76$ & 39,862 & 104,118 & 144,100 \\
& $1976-77$ & 25,000 & 114,000 & 139,600 \\
& 197000 & 104,000 & 128,000 \\
\hline
\end{tabular}

Source: Department of Statistics

Domestic exports of sugar and bananas is shown for the period 1955-1977 and as a percentage of Domestic Exports. 
TABLE III - 24

DOMESTIC EXPORTS OF SUGAP. AND BANANA 1955-1977

\begin{tabular}{|c|c|c|c|c|c|c|c|c|}
\hline \multirow[b]{2}{*}{ Year } & \multicolumn{2}{|c|}{ SUGAR } & \multicolumn{2}{|c|}{ BANANA } & \multicolumn{2}{|c|}{ TOTAL } & \multirow{2}{*}{$\begin{array}{c}\% \text { of } \\
\text { Domestic } \\
\text { Exports }\end{array}$} & \multirow{2}{*}{$\begin{array}{c}\text { Total } \\
\text { Domestic } \\
\text { Exports } \\
\phi^{\circ} 000\end{array}$} \\
\hline & $\begin{array}{l}\text { Tooo } \\
\text { tons }\end{array}$ & $\$ 1000$ & $\begin{array}{l}\text { To00 } \\
\text { tons }\end{array}$ & $\$ 000$ & $\begin{array}{l}\text { Toon } \\
\text { tons }\end{array}$ & $\$, 000$ & & \\
\hline 1955 & 289 & 21,602 & 10,852 & 10,040 & 11,141 & 31,642 & 48.8 & 64,854 \\
\hline 1956 & 372 & 25,179 & 11,218 & 12,171 & 11,590 & 37,350 & 48.8 & 76,468 \\
\hline 1957 & 303 & 25,113 & 11,370 & 13,600 & 11,673 & 38,713 & 39.1 & 99,070 \\
\hline 1958 & 278 & 20,741 & 9,966 & 9,994 & 10,244 & 30,735 & 33.0 & 93,056 \\
\hline 1959 & 312 & 23,318 & 10,274 & 9,888 & 10,586 & 33,206 & 36.7 & 90,536 \\
\hline 1960 & 353 & 25,957 & 10,175 & 9,616 & 10,528 & 35,573 & 31.9 & 111,522 \\
\hline 1961 & 380 & 28,458 & 5,980 & 9,780 & 6,360 & 38,238 & 31.5 & 121,264 \\
\hline 1962 & 379 & 29,162 & 6,337 & 9,023 & 6,716 & 38,185 & 30.7 & 124,470 \\
\hline 1963 & 394 & 42,458 & 160 & 9,688 & 554 & 52,146 & 37.1 & 140,368 \\
\hline 1964 & 417 & 39,206 & 174 & 12,089 & 591 & 51,295 & 33.9 & 151,152 \\
\hline 1965 & 424 & 31,253 & 200 & 12,208 & 624 & 43,461 & 29.0 & 149.872 \\
\hline 1966 & 408 & 33,205 & 200 & 12,676 & 608 & 45,881 & 23.7 & 193,300 \\
\hline $1967 *$ & $523 *$ & 30,183 & 190 & 13,124 & 713 & 43,307 & 22.3 & 193,800 \\
\hline 1968 & 383 & 34,048 & 153 & 13,800 & 536 & 47,848 & 23.5 & 203,300 \\
\hline 1969 & 294 & 27,937 & 151 & 12,469 & 445 & 40,406 & 19.6 & 206,100 \\
\hline 1970 & 293 & 30,022 & 134 & 11,822 & 427 & 41,844 & 15.0 & 279,116 \\
\hline 1971 & 460 & 29,987 & 126 & 11,722 & 586 & 41,709 & 15.2 & 275,203 \\
\hline 1972 & 276 & 33,765 & 127 & 11,822 & 403 & 45,587 & 15.6 & 293,077 \\
\hline 1973 & 261 & 35,369 & 108 & 16,268 & 369 & 51,637 & 14.8 & 347,841 \\
\hline 1974 & 270 & 74,422 & 72 & 11,411 & 342 & 85,853 & 13.4 & 641,639 \\
\hline 1975 & 254 & 139,688 & 68 & 14,654 & 322 & 154,342 & 21.2 & 727,312 \\
\hline 1976 & 230 & 55,859 & 77 & 11,921 & 307 & 67,780 & 12,1 & 561,623 \\
\hline 1977 & $217^{*}$ & 67,192 & $76 *$ & 16,278 & 293 & 83,470 & 12.0 & 693,412 \\
\hline
\end{tabular}

*Provisional

Source: Indices of External Trade 1969-1977 
Sugar production in 1977 of 217,000 tons was the lowest in 23 years only 40 percent of total sugar production in 1967, ten years earlier. Similarly for bananas. Compare 1977 banana production of 80,000 tons with production in 1957 of 11.3 million tons.

Constant demands are being made on the agricultural sector to expand to meet local food requirements due to restrictions placed on imported food and raw materials. An emergency production plan was launched in 1977 and efforts concentrated on crops requiring short maturity periods. A "Land Lease Project" was started under which a gross acreage of 109,000 acres, with 61,307 arable acres, on 448 properties were leased to 31,364 tenants up to January 1978. Also a "Crop Lein" programme aimed at making special credit available to sma11 farmers producing selected crops. ${ }^{1}$

In the most recent five-year plan the targeted growth rate for agriculture is 7-8 percent per annum, Domestic food crop production is to expand by an additional 90,000 crop-acres over the same five year period. "Crop-acre" refers to the number of acres of various crops planted during a year, that is more intensive use of acreage. This will be made possible by bringing idle lands into production. It is estimated there are $65 ; 000$ acres of arable 1 ands on properties of over 100 acres laying idle. ${ }^{2}$ Also making other lands suitable for intensive production through drainage,

${ }^{1}$ Economic and Social Survey, Jamaica 1977. op.cit., p.115

${ }^{2}$ Five Year Development Plan, Jamaica 1978-82, op.cit.., p.10 
irregation or terracing of steep slopes. Agriculture's share of the "classifiable labor force" has declined from 45 percent in 1943 to 34 percent in 1972. For the year 1977, the "classifiable labor force" totalled 917,900 of which an average of 243,500 were employed in the industry during the year that is 26.5 percent of the labor force or $30 \%$ of those employed in 1977. There are many contributing factors for the present state of the agriculture sector. Generally the farms are too small to be economically profitable and so the farmers often have to engage in non-farm activities to supplement their incomes. The farmers knowledge of management and husbandry is poor. The crops are grown in a mixed stand, interplanted with other, and many crops are planted on lands unsuitable for their production. On the other hand there are few direct linkages between the industry and the rest of the economy. More importantly the depression in agriculture has been the product of the historical stigma attached to it, and aversion to work on the soil, a stigma reinforced by the low income level prevailing in the sector.

The depressed state of the agricultural sector is accompanied by increasing dependence on imported foods which could be produced locally. In general the receipts from domestic agricultural exports is insufficient to cover the island's import bill. This all points to the need for a transformation of the agricultural sector through land reform programs started and providing the farmers with the technical assistances needed--credit and marketing facilities, educational and recreational amenities. 


\section{THE MINEPAL INDUSTRY}

The mineral sector is comprised of bauxite mining, processing of bauxite into alumina; mining of gypsum, silica sand, marble and alabaster; quarrying sand, gravel and marl; production of industrial lime and prospecting for metals and oil.

The bauxite and alumina industry is Jamaica's major foreign exchange earner. In 1977 the industry accounted for 70 percent of Jamaica's exports, 30 percent of Government's nonloan revenues and 11 percent of the Gross Domestic Product ${ }^{1}$ in real terms.

Discovery and Development

Deposits of aluminous red earth was known to have existed in the Tertiary Limestone Districts of Jamaica since the $1820^{\prime} \mathrm{s}^{2}$ As a result of soil investigation carried out between 1938-1942 by the Agricultural Chemistry Laboratory of the Department of Agriculture, the commercial importance of the bauxite deposits were confirmed. February 1943, a trial shipment of 2,500 tons of the bauxite were sent to the United States for testing. However, due to its chenical composition and physical properties, the material was not amenable to processing in the then existing North American factories, and so immediate processing was not possible. ${ }^{3}$ The processing had to be altered to handle Jamaica bauxite.

${ }^{1}$ Five-Year Plan Jamaica 1978-82, op.cit,p. 29.

${ }^{2}$ overseas Geological Surveys, Mineral Resources Division Bauxite Alumina and Aluminium, (London) p. 110 .

3 Ibid. p. 111. 
The real beginning of the industry only dates back to 1952 with the mining and export of kiln dried bauxite by Reynolds Jamaica Mines Limited, a wholly-owned subsidiary of Reynolds Metal Company. Shortly after, alumina was produced and exported by Alumina Jamaica Limited, a subsidiary of Aluminium Company of Canada. During the nine-year period 1952-1960, it is estimated that Jamaica's output of bauxite totalled 30.5 million tons (dried equivalent). Of this amount, 24.6 million tons were exported and 5.9 million tons used for production of alumina. ${ }^{1}$

Bauxite reserves are estimated to be between $1.2-2.0$ billion metric tonnes, and are the fourth largest measured reserves of aluminium ore in the world. ${ }^{2}$ It is estimated that about one-half of the known resources are located in the parish of Manchester, about one-third in St. Ann and the remainder scattered about five or six other parishes.

The chief deposits occur at an altitude of 2,000 to 2,700 feet above sea-level on the Manchester Plateau, also between 800 to 2,000. feet near the Eastern boundary of the plateau, and on the St. Ann Plateau 1,200 to 1,500 feet.

Bauxite deposits are usually found in areas covered by White Limestone Formation which covers five-eights of total

\footnotetext{
Ioverseas Geological Survey, op.cit,p. 113. ${ }^{2}$ Five Year Plan 1978-82, op.cit,p.29.
} 
land area. The deposits are covered by a thin layer of soil. The depths of the deposits vary from over 100 feet to only a few inches. Average depth is about 20 feet and deposits under 5 feet are not considered of commercial use.

Bauxite is a soft to moderately hard, extremely finegrained porous, earthy material of a dark-red, reddish-brown, yellowish-brown colour ${ }^{1}$, depending on the amount and nature of the iron content. Most Jamaican ore is in the form of gibbsite and the remainder in the form of boehmite. Ore of gibbsitic composition is readily amenable to American Bayer conditions of temperature and caustic concentration. Using this process, a ton of ore should yield 0.45 tons of alumina. ${ }^{2}$

The processing of bauxite to aluminium has three stages. In Phase one the ore is crushed, washed and dried to produce dried ore. Phase Two is benefication - alumina is extracted from the dried ore by a chemical process. Phase Three is the extraction of aluminium from alumina via smelting requiring large amounts of power. Generally, it takes $2-3$ tons of bauxite to produce a ton of alumina and $2-3$ tons of alumina to make a ton of aluminium. 3

1 overseas Geological Survey,op.cit,p, 114.

${ }^{2}$ Ibid.

${ }^{3}$ Iserdo Jainarain, op.cit,p. 273. 
The value added is about 250 percent in the second stage and about 22 percent in the third stage. 1 Jamaica only participates in the first and second stages.

The decision to locate processing outside the host countries has been the main reason for loss of potential benefits. The establishment of refining facilities was hampered by the small size of the country and its inability to support a capital goods industry, and also the unavailability of a cheap source of electric power.

At the beginning there were only three companies operating in Jamaica - Reynolds, Kaiser and Alcan. Reynolds and Kaiser concentrated exclusively on the extraction of the ore, whereas from the beginning Alcan processed all its ore into alumina for export. In 1963, Alcoa started extracting bauxite and in 1972 its alumina plant started operations. $1969 \mathrm{saw}$ Alumina Partners of Jamaica (a consortium of Kaiser, Reynolds and Anaconda) producing alumina, and in 1971 Revere Copper and Brass set up an alumina plant.

Presently there are five companies operating in the industry, two still mine and export the dried ore, while three others operate four extraction plants producing alumina. The increased alumina processing has been the result of Government policies aimed at maximum local processing.

${ }^{1}$ Calculated from $H$. D. Huggins, Aluminium in Changing Communities (London, Andre Deutsch, 1965, p. II. Girvan gives nigner tigures than Huggins - 320 percent in the second stage and 265 percent in the third. See Norman Girvan, The Caribbean Bauxite Industry, Jamaica, University of the West Indies, 1967, p. 3. 
Since 1974, Government involvement in the industry increased in terms of ownership and earnings. Table III-25 shows the companies mining the bauxite ore and the structure of ownership at 1978 .

\section{Table III -25}

OWNERSHIP IN THE JAMAICAN BAUXITE/ALUMINA INDUSTRY

1. JAMALCAN

2. Alumina Partners of JAMAICA Ltd. (ALPART)

3. JAMALCO

4. Kaiser Bauxite

5. Reynolds Mines Jamaica Limited

6. (Revere Alumina*)
Alcan Aluminium Ltd. Government of JAMAICA

$93 \%$

$7 \%$

Anaconda Aluminium

Kaiser Aluminium

Reynolds Metals

Aluminium Company of America

Government of JAMAICA

Government of JAMAICA

Kaiser Aluminium

Government of JAMAICA $51 \%$ Reynolds Metals

(Revere Copper and Brass)

* Ceased operations in 1975.

Source: Five Year Development Plan 1978-82. 
The bauxite-alumina industry is still today dominated by American multi-national, vertically-integrated concerns, although the Government of Jamaica has made strides in reducing foreign ownership and increasing the share to Jamaica from increased production, through such measures as increased royalty payments and imposition of a production levy. The companies do the entire processing from mining of the bauxite, through benefication into alumina, smelting into alumina and finally to the manufacture of the aluminium into semi-fabricated aluminium products. The companies also are involved in the production of the inputs needed for processing of the ore at various stages - such as caustic soda, flourspar, cryolite and carbon and electric power required for the later stages. The bargaining power of these giants can only be imagined. These multinational giants, through imports from their parent company, provide for all their needs of capital, machinery, management and skilled personnel, thereby internalizing all their profits.

Bauxite is extracted and processed exclusively by the aluminium companies. There is really no free trade in bauxite anywhere in the world as there are for traditional exports. Performance of the Bauxite-Alumina Industry

In the Emergency P1an of 1977, the mining sector was identified as the area for development to produce the needed foreign exchange earnings. Production targets were set for production of bauxite and alumina in 1977. This is compared to actual performance in Table III-26. 
Table III- 26

TARGET AND ACTUAL OUTPUT OF BAUXITE AND ALUMINA

\begin{tabular}{|c|c|c|c|c|c|c|}
\hline & $\begin{array}{l}\text { Total Prod. } \\
\text { (Million } \\
\text { Metric } \\
\text { Tons) }\end{array}$ & $\begin{array}{l}(\%) \text { Change } \\
1977-1976\end{array}$ & $\begin{array}{l}\text { Capacity } \\
\text { Used }(\%)\end{array}$ & $\begin{array}{l}\text { Exports } \\
\text { (Milion } \\
\text { Metric } \\
\text { Tons) }\end{array}$ & $\begin{array}{l}\left(\begin{array}{l}0 \\
0\end{array}\right) \text { Change } \\
1977-1976\end{array}$ & $\begin{array}{l}\text { Capacity } \\
\text { Used (\%) }\end{array}$ \\
\hline 1976 & 10,311 & $\cdots$ & 68 & 1,621 & -- & 61 \\
\hline $\begin{array}{l}1977 \\
\text { (Target) }\end{array}$ & 12,548 & 22 & 83 & 2,400 & 48 & 90 \\
\hline $\begin{array}{l}1977 \\
\text { (Actual) }\end{array}$ & 11,433 & 11 & 75 & 2,034 & 25 & 76 \\
\hline
\end{tabular}

Source: Economic and Social Survey, 1977.

Production in 1977 never actually attained the target levels, but nevertheless was still in excess of 1976 output. Real Contribution to Gross Domestic Product by this sector was $\$ 214.5$ miliion, an increase of $\$ 31.2$ million over $1976^{\prime} \mathrm{s}$ figure of $\$ 183.3$ million. This was the result of an 11 percent growth in output of bauxite, a 26 percent increase in output of alumina and a 21 percent rise in output of industrial 1 ime. ${ }^{1}$ The targeted growth rate for $1978-82$ is $5-6 \%$ per annum, according to the most recent five year plan. Total production of bauxite in 1977 was 11,433 million metric tons, about 9 percent lower than the targeted 1977 output. Data on the production of bauxite for $1973-1977$ is presented in Table I I I - 27 .

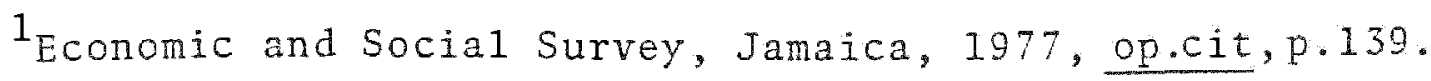


Table III -27

BAUXITE AND ALUMINA PRODUCTION: 1973-1977

EXPORTED PROCESSED LOCALLY

\begin{tabular}{|c|c|c|c|c|c|c|}
\hline Year & $\begin{array}{l}\text { Quantity } \\
\text { ('000 } \\
\text { Metric } \\
\text { Tons) } \\
\end{array}$ & $\begin{array}{l}\left(\frac{0}{8}\right) \text { of } \\
\text { Total } \\
\text { Production }\end{array}$ & $\begin{array}{l}\text { Quantity } \\
\text { ('000 } \\
\text { Metric } \\
\text { Tons) }\end{array}$ & $\begin{array}{l}\left(\frac{0}{6}\right) \text { of } \\
\text { Total } \\
\text { Production }\end{array}$ & $\begin{array}{l}\text { Total } \\
\text { Bauxite } \\
\text { ('000 } \\
\text { Metric } \\
\text { Tons) } \\
\end{array}$ & $\begin{array}{l}\text { Alumina } \\
\text { Exported } \\
\text { ('000 } \\
\text { Metric } \\
\text { Tons) } \\
\end{array}$ \\
\hline 1973 & 7,389 & 54.3 & 6,210 & 45.7 & 13,600 & 2,316 \\
\hline 1974 & 7,999 & 52.0 & 7,328 & 48.0 & 15,328 & 2,851 \\
\hline 1975 & 5,482 & 47.4 & 6,088 & 52.6 & 11,570 & 2,336 \\
\hline 1976 & 6,284 & 60.9 & 4,027 & 39.1 & 10,311 & 1,644 \\
\hline 1977-target & 6,797 & 54.2 & 5,751 & 45.8 & 12,548 & 2,500 \\
\hline 1977-actual & 6,355 & 55.6 & 5,078 & 44.4 & 11,433 & 2,035 \\
\hline 1978-provisional & $\mathrm{N} / \mathrm{A}$ & $N / A$ & $N / A$ & N/A & 11,555 & N/A \\
\hline
\end{tabular}

Source: Economic and Social Survey, 1977.

Since 1974 , Jamaica's contribution to world production of bauxite has fallen from 19.6 percent to 13.4 percent in 1977 . This is shown in Table III-28. 
Table III- 28

BAUXITE PRODUCTION BY SELECTED COUNTRIES AS A PERCENTAGE OF TOTAL WORLD PRODUCTION

\begin{tabular}{|c|c|c|c|}
\hline Country & $\begin{array}{l}\text { Percentage of } \\
1974\end{array}$ & $\frac{\text { Wor } 1 \mathrm{~d}}{1976}$ & $\begin{array}{r}\text { Production } \\
1977 \\
\end{array}$ \\
\hline Australia & 25.7 & 30.1 & 30.5 \\
\hline $\begin{array}{l}\text { Dominican } \\
\text { Republic }\end{array}$ & 1.9 & 0.7 & 0.8 \\
\hline Guinea & 6.4 & 14.1 & 12.7 \\
\hline Jamaica & 19.6 & 12.9 & 13.4 \\
\hline Surinam & 8.2 & 5.8 & 5.8 \\
\hline (Caribbean) & 34.7 & 23.8 & 24.8 \\
\hline
\end{tabular}

Source: Five Year Development Plan 1978-82.

The industry produces exclusively for the export market. Statistics for domestic exports of bauxite and alumina for the period 1955-1977 and their contribution to total domestic exports is presented in Table III-29. In 1950, the mining sector was based on quarrying and gypsum, and accounted for less than one percent of Gross Domestic Product. ${ }^{1}$ With the introduction of bauxite-alumina, the sector's real contribution has risen to a high of 13 percent in 1974 , falling since to 8.7 percent and up to almost 11 percent in 1977. Exports of bauxite and alumina have risen from 26 percent of total domestic exports in 1955 to account for 74 percent of domestic exports in 1977 . 
Table III-29

DOMESTIC EXPORTS OF BAUXITE AND ALUMINA,

1955-1977

\begin{tabular}{|c|c|c|c|c|c|c|c|c|}
\hline \multirow[b]{2}{*}{ Year } & \multicolumn{2}{|c|}{ BAUXITE } & \multicolumn{2}{|c|}{ ALUMINA } & \multicolumn{2}{|c|}{ TOTAL } & \multirow{2}{*}{$\begin{array}{l}\frac{0}{6} \text { of } \\
\text { Domestic } \\
\text { Exports }\end{array}$} & \multirow{2}{*}{$\begin{array}{l}\text { Total } \\
\text { Domestic } \\
\text { Exports } \\
\$ 1000\end{array}$} \\
\hline & $\begin{array}{l}000 \\
\text { tons }\end{array}$ & $\$: 000$ & $\begin{array}{l}1000 \\
\text { tons } \\
\end{array}$ & $\$ 000$ & $\begin{array}{l}\text { Toon } \\
\text { tons }\end{array}$ & $\$ 1000$ & & \\
\hline 1955 & 2,172 & 7,768 & 184 & 9,568 & 2,356 & 17,336 & 26.7 & 64,854 \\
\hline 1956 & 2,575 & 9,200 & 207 & 11,606 & 2,782 & 20,806 & 27.2 & 76,468 \\
\hline 1957 & 3,641 & 19,126 & 436 & 23,822 & 4,077 & 42,948 & 43.4 & 99,070 \\
\hline 1958 & 4,799 & 25,194 & 373 & 18,264 & 5,172 & 43,458 & 46.7 & 93,056 \\
\hline 1959 & 4,197 & 22,032 & 399 & 18,812 & 4,596 & 40,844 & 45.1 & 90,536 \\
\hline 1960 & 4,148 & 21,774 & 665 & 33,268 & 4,813 & 55,042 & 49.4 & 111,522 \\
\hline 1961 & 4,975 & 26,118 & 703 & 33,770 & 5,678 & 59,888 & 49.4 & 121,264 \\
\hline 1962 & 5,986 & 31,430 & 628 & 28,846 & 6,614 & 60,276 & 48.4 & 124.470 \\
\hline 1963 & 5,162 & 27,100 & 726 & 31,902 & 5,888 & 59,002 & 42.0 & 140,368 \\
\hline 1964 & 5,967 & 31,328 & 768 & 36,368 & 6,735 & 67,696 & 44.8 & 151,152 \\
\hline 1965 & 6,784 & 35,618 & 721 & 34,986 & 7,505 & 70,604 & 47.1 & 149,872 \\
\hline 1966 & 7,020 & 70,196 & 791 & 38,634 & 7,811 & 108,830 & 56.3 & 193,300 \\
\hline 1967 & 7,142 & 71,420 & 824 & 41,772 & 7,966 & 113,192 & 58.4 & 193,800 \\
\hline 1968 & 6,212 & 62,120 & 868 & 50,833 & 7,080 & 112,953 & 55,6 & 203,300 \\
\hline 1969 & 7,601 & 46,559 & 1,177 & 70,226 & 8,778 & 116,785 & 56.7 & 206,100 \\
\hline 1970 & 7,575 & 75,752 & 1,768 & 111,141 & 9,343 & 186,893 & 67.0 & 279,116 \\
\hline 1971 & 7,590 & 74,630 & 1,752 & 104,316 & 9,342 & 178,946 & 65.0 & 275,203 \\
\hline 1972 & 7,049 & 68,375 & 2,102 & 119,867 & 9,151 & 188,242 & 64.4 & 292,277 \\
\hline 1973 & 7,274 & 79,469 & 2,576 & 147,769 & 9,850 & 227,238 & 65,3 & 347,841 \\
\hline 1974 & 7,873 & 121,718 & 2,772 & 337,313 & 10,645 & 459,031 & 71.5 & 641,639 \\
\hline 1975 & 5,396 & 97,475 & 2,337 & 389,817 & 7,733 & 487,292 & 67.0 & 727,312 \\
\hline 1976 & 6,185 & 113,738 & 1,596 & 274,935 & 7,781 & 388,673 & 69.2 & 561,623 \\
\hline 1977 (a) & 6,355 & 145,896 & 2,034 & 343,283 & 8,389 & 489,179 & 74.7 & 655,267 \\
\hline $1977(\mathrm{~b})$ & & & & & & & 70.5 & 693,412 \\
\hline
\end{tabular}

Source: External Trade 
The Government has been negotiating agreements with the individual bauxite companies in achievement of their objectives for increased participation in earnings, ownership and diversification of market outlets for bauxite-alumina. The objectives include:

1. Acquiring all non-operating mining lands - In the most recent five year plan, it is stated the Government intends to buy back 195,000 acres or 92.5 percent of the companies' lands; that is, a11 land with the exception of land that is integral to their mining and processing operations.

2. Acquiring equity participation in bauxite-alumina operations in Jamaica. 51 percent participation in Kaiser was purchased at US\$13.8 million, payable over 10 years at 8.5 percent interest per annum, and in Reynolds at US\$7.2 million, payable over 10 years at 8 percent interest. ${ }^{1}$

3. Allocation of reserves on a 40 year guarantee basis.

4. A basic production levy fixed at 7.5 percent of the realized price of aluminium ingot for an 8 year period was started in 1974.

The production levy placed on al1 mined bauxite, whether for export or local processing into alumina, in addition to 
increased royalty payments by the companies, led to an increase in Government revenues and foreign exchange earnings. Direct earnings from the industry increased from $J \$ 24,503,694$ in 1973 (for a total production of $12,599,383$ tonnes) to $\$ 168,521,978$ in 1974 (for a total production of 15,328,503 tonnes). 1

The payment of Production Levy and Royalties by bauxite and alumina companies to the Government of Jamaica is depicted in the table below.

Table III -30

PAYMENT OF PRODUCTION LEVY AND ROYALTIES BY BAUXITE AND ALUMINA COMPANIES TO THE GOVERNMENT OF JAMAICA.

\begin{tabular}{lcccc} 
Year & Production Levy & Corporate Taxes & Royalties & Total \\
\hline 1973 &.-- & 21.0 & 3.5 & 24.5 \\
1974 & 161.7 & -- & 7.0 & 168.7 \\
1975 & 134.0 & -- & 5.4 & 139.4 \\
1976 & 113.8 & -- & 4.8 & 118.6 \\
1977 & 167.1 & -- & 5.2 & 172.3
\end{tabular}

* Companies are not required to pay both Corporate Taxes as well as Production Levy. The Production Levy figures are net of rebates to Bauxite and Alumina Companies.

Payments in U.S. Dollars were converted at the "basic rate of US $\$ 1.10=J \$ 1.00$.

Source: Economic and Social Survey.

IFive Year Development Plan, Jamaica, 1978-82, p.31. 
Since the industry is highly capital intensive, its contribution to employment is sma11. According to the Labor Force Survey, employment in mining and quarrying was estimated at 7,500 in October, 1977, out of a total classifiable labor force of 917,900 at the same date, 1.0 percent of those employed. There was a reduction of 900 from the 8,600 employed in October, 1976. Table III-31 shows this.

Table III-31

EMPLOYMENT - MINING AND QUARRYING: 1974-1977

$19741975 \quad 1976 \quad 1977$

April October April October April October April October

No. Employed $\quad 7,100 \quad 8,300 \quad 7,600 \quad 7,300 \quad 7,300 \quad 8,400 \quad 7,200 \quad 7,500$

Source: Economic and Social Survey.

The fact that production has increased yet employment has decreased attests to the capital intensive nature of the industry. 
Industrial Materials

Output in 1977 was adversely affected by the relatively low activity level in the construction sector. Production of gypsum, sand and gravel, silica sand and marble declined, whereas industrial lime increased. Production of Industrial Minerals for the period 1974-1977 is shown below.

Table III- 32

PRODUCTION OF INDUSTRIAL MINERALS

$1974-1977$

\begin{tabular}{|c|c|c|c|c|c|}
\hline Product & $\begin{array}{l}\text { Unit of } \\
\text { Quantity }\end{array}$ & 1974 & 1975 & 1976 & 1977 \\
\hline Gypsum & $\begin{array}{l}1000 \\
\text { long tons }\end{array}$ & 264.5 & 235.8 & 249.2 & 210.0 \\
\hline $\begin{array}{l}\text { Industrial } \\
\text { Lime }\end{array}$ & $\begin{array}{l}1000 \\
\text { long tons }\end{array}$ & 230.0 & 180.0 & 240.0 & 290.0 \\
\hline $\begin{array}{l}\text { Silica } \\
\text { Sand }\end{array}$ & $\begin{array}{l}1000 \\
\text { long tons }\end{array}$ & 26.8 & 32.5 & 25.8 & 24.3 \\
\hline Marble & $\begin{array}{l}1000 \\
\text { long tons }\end{array}$ & 0.6 & 0.6 & 0.8 & 0.1 \\
\hline $\begin{array}{l}\text { Sand and } \\
\text { Grave1 }\end{array}$ & $\begin{array}{l}\text { '000 cubic } \\
\text { yards }\end{array}$ & $4,000.0$ & $6,000.0$ & $3,500.0$ & $3,000.0$ \\
\hline $\begin{array}{l}\text { Fill (marl } \\
\underset{\&}{q} \text { rubble) }\end{array}$ & $\begin{array}{l}\text { '000 cubic } \\
\text { yards }\end{array}$ & $7,600.0$ & $7,000.0$ & $6,000.0$ & $6,000.0$ \\
\hline
\end{tabular}

Source: Economic and Social Survey 


\section{MANUFACTURING}

Performance

The manufacturing sector was the largest contributor to the Gross Domestic Product in 1977. It accounted for $\$ 353$ milion, that is, 17.5 percent of GDP, despite a decline of 5.5 percent in its output for the year. In 1977, this sector was the fifth largest employer of labor, accounting for 76,000 jobs, that is, approximately 8 percent of the total labor force of 917,900 . Its earnings from exports of selected manufactured goods amounted to $\$ 144.8$ million in 1977 , but this was due largely to the valuation of exports at the special exchange rate. If the basic rate was applied, i.e., the exchange rate existing in 1976 , earning would have declined.

The year 1978 saw marginal increases in production of manufactured and semi-manufactured goods as import restrictions on raw materials, particularly for export-oriented items, was slightly eased.

Problems Encountered in the Industry

The performance of the manufacturing sector has been severely hampered by the small size of the population, low per capita income level and limited natural resources and raw material availability. These factors restrict industrialization on a large scale. They limit the size of the domestic market to only a few consumer goods industries, while the tariffs and quota restrictions in foreign markets discriminate against imports from 
countries such as Jamaica where 1 abor and production costs may be lower. As a British Colony, Jamaica's role was to supply the raw materials for manufacture, such as raw sugar to the Metropole and be an accessible market for its manufactured goods.

The capital intensive technology, borrowed from the developed nations and utilized in small Third World countries like Jamaica, is often unsuitable for production on the small scale needed to supply domestic demand. This results in underutilization of plant and machinery capacity, inefficient production methods and overal1 wastes.

In addition, consumer goods produced locally faces certain prejudices and resistances. In the Caribbean, consumers place a higher value on imported items than on locally produced substitutes. Local substitutes are regarded as inferior and are suspect for quality. The suspicion about quality is often due to the relaxed enforcement of set standards of quality, also the monopolistic conditions under which the items are manufactured. As imports are restricted, it is possible for domestic output to increase of margarine, condensed milk, paints, fertilizers, soaps-until a point of saturation is reached. This is not often the case due to worker disagreements, work stoppages and raw material shortages. Also the local substitutes are higher priced than the imports they replace. The guaranteed market conditions make this possible, via protective tariffs and licenses aimed at developing the age-old "infant" industries. 
The economy exhibits a high level of dependence on imported raw materials, some of which with adequate research and planning could be supplied locally. The real domestic value added is basically confined to the employment utilized in the production process.

The high level of migration has had the effect of not only removing the enterprising entrepreneural class, but also the skilled workers. Local entrepreneurs with available capital generally show a preference for the distributive trades rather han manufacturing, due to the higher risks involved.

In 1977 , the manufacturing sector was adversely affected by the negative foreign exchange situation which necessitated tighter licensing of imports of raw materials and capital goods. The establishment of the two-tier exchange rate structure in April 1977 had the effect of increasing the cost for these essential imports which attracted the special devalued rate (approximately 40 percent).

Many firms suffered cash flow problems, due to the sluggish local market situation and their inability to collect outstanding debts. The commercial banks, although highly liquid, discouraged loans with the maintenance of high interest rates on loans, averaging approximately 14 percent. ${ }^{1}$ In addition, the depressed state of the Construction Industry reduced demand for inputs from the manufacturing sector. Also, there were numerous industrial

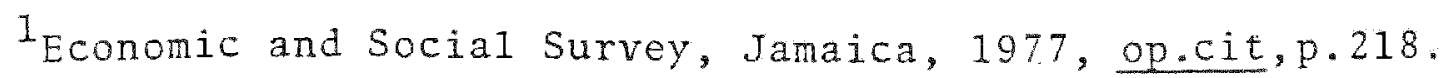


disputes triggered off by restraints on wages and worker benefits and proposals for worker retrenchment, due to rising costs and declining business. In fact, employment in large establishments (i.e., firms employing 10 or more persons) has been declining since March, 1976. The estimated number of employees in such firms at December, 1977 was 44,690 , a reduction of 17.1 percent of the figure of 53,880 for March, 1976. This loss of employment was concentrated in the wage earning group. Total employment in the Manufacturing Industry is shown in Table III-33

Table III- 33

CLASSIFIABLE LABOR FORCE AND EMPLOYMENT IN MANUFACTURING: $1974-1977$

$\begin{array}{cccc}1974 & 1975 & 1976 & 1977 \\ \text { April October April October April October } & \text { April October }\end{array}$

Labor Force $^{*} \quad 98,800 \quad 97,900 \quad 89,400 \quad 95,200 \quad 95,200 \quad 96,500 \quad 101,200 \quad 96,700$

Enployment $\quad 81,400,81,100 \quad 75,200 \quad 72,700 \quad 76,100 \quad 75,000 \quad 77,600 \quad 74,900$

* The labor force is comprised of:

(a) Persons currently employed in the sector.

(b) Persons currently unemployed whose last job was in this sector.

Source: Economic and Social Survey. 
The targeted growth, according to the most recent Five Year Development PIan, is for a 4-5 percent growth per annum, based on both large and small enterprises, craft activities and "community cooperative" enterprises. The objectives are to include:

(i) Adequate production of basic domestic items in the areas of processed foods, construction materials, footwear, clothing and pharmaceuticals;

(ii) Development of increased linkages within the ecoromy

(iii) Intensive utilization of already installed capacity in manufacture;

(iv) Realization of the potential for utilizing local raw materials;

(v) Generation of 14-16 percent increase per annum in foreign exchange earnings from exports of manufacture. 


\section{Construction and Installation}

The activities of the Construction and Installation sector includes both housing and non-housing construction and installation. This sector of the economy has the ability to increase the level of fixed capital formation in the economy and is a general indicator of the activities in the other sectors. The performance of this sector is a reflection of the level of investment in the economy. A decline in this sector is indicative of a decline in investment demand, in production and sales of building materials-cement, steel and other construction materials, in fixed capital formation and reduction of employment.

\section{Cement}

Cement was produced in 1977 at approximately 18 percent below the capacity of the Cement Plant. Production declined by 31,000 tons to 328,000 tons $\left(333,248\right.$ tonnes). ${ }^{1}$ Table III-34 gives Production and Sales of Cement for the period 1973-1977.

Table III -34

Production and Sales of Cement 1973-1977

(000 tons)

\begin{tabular}{|lllllll|}
\hline & 1973 & 1974 & 1975 & 1976 & 1977 & 1978 \\
\hline Production & 397 tons & 393 tons & 399 tons & 359 tons & 328 tons & 288.9 \\
Local Sales & $418 *$ & $408 * *$ & $424 * * *$ & 359 & 321 & tons \\
Export & 1.8 & 0.54 & -- & -- & 7.0 & \\
\hline
\end{tabular}

* includes approximately 5,300 tons imported December 1973

** includes approximately 32,400 tons imported December 1974

$* * *$ includes approximately 7,536 tons imported December 1975

Source: (1) Economic and Social Survey

(2) Department of Statistics 
Steel

Steel production declined for 1977 by 25 percent or 3,463 tons. Production was affected by the cessation of operations for four months in the Melt Shop due to an accident at the steel plant at the end of September 1977. The damaged equipment was repaired and full resumption of operations took place in February 1978. Table III-35 gives output and sales of steel for 1973-1978.

Table III-35

Output and Sales of Steel for $1973-1978$

\begin{tabular}{|ccccccc|}
\hline & 1973 & 1974 & 1975 & 1976 & 1977 & 1978 \\
\hline & tons & tons & tons & tons & tons & tons \\
\hline Production & 17,824 & 16,292 & 20,767 & 13,653 & 10,190 & 14,000 \\
$\begin{array}{l}\text { Sales } \\
\text { (Caribbean }\end{array}$ & & & & & & \\
$\quad$ Stee1) & 18,765 & 13,382 & 21,009 & 15,981 & 11,483 & \\
Imports & 33,136 & 35,438 & 8,954 & 10,841 & 6,135 & \\
\hline
\end{tabular}

Source: Economic and Social Survey

Imports of steel in 1977 was inadequate to meet the shortfall in local production. Total sales of steel amounted to 17,618 tons, that is, 9,204 tons less than sales in 1976 .

Other Local Materials

This category includes bagasse and paints. Bagasse board production declined by $11.2 \mathrm{million}$ square feet in 1976 to 3.5 milion square feet in 1977 ; a decline of 68.5 percent. Paint 
production was also 191,000 gallons, 15 percent below 1976 production. 1

Table III-36 shows the amount of Fixed Capital formation by the construction sector. Building construction related to residential and non-residential construction while other construction includes roads and other public works and land improvements. Total capital formation has been declining since 1975.

Table III- 36

Composition of Fixed Capital Formation by Type of Capital Goods

$(\$ \cdot 000)$

\begin{tabular}{|c|c|c|c|c|}
\hline Type of Capital Goods & 1974 & 1975 & 1976 & 1977 \\
\hline Building Construction & 230,440 & 273,659 & 226,593 & 201,768 \\
\hline $\begin{array}{l}\text { Other Construction in- } \\
\text { cluding land improve- } \\
\text { ments }\end{array}$ & 31,824 & 23,194 & 17,503 & 11,027 \\
\hline Transport Equipment & 58,833 & 96,197 & 37,907 & 17,507 \\
\hline Machinery \& Equipment & 157,100 & 218,755 & 167,164 & 112,706 \\
\hline Gross Fixed-Capital & 478,197 & 611,805 & 499,167 & 343,008 \\
\hline
\end{tabular}

Change in Gross Fixed Capital Fornation 1974-1977 $=-28.3 \%$

Change in Gross Fixed Capital Formation 1975-1977 $=43.9 \%$

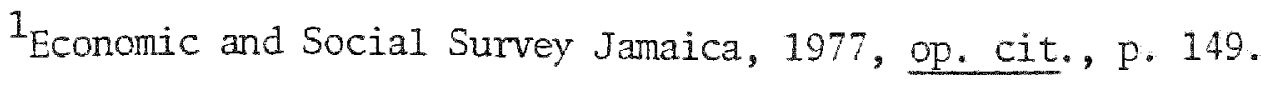


Contribution of the Industry

The contribution of the Construction sector shows a decline since 1975. At constant prices the value declined from $\$ 176.3$ million in 1976 to 143.3 million, over 18 percent. In 1977 it contributed only 7.1 percent to the Gross Domestic Product in real terms. The sector has been faced with a decline in the demand for houses as well as non-residential construction. This has been the result of high escalating construction costs reducing demand, and the generally depressed economic conditions resulting in a reduced demand for new construction.

Since early 1978 some Building Societies have reduced their interest rates on mortgages from 12 percent to 11 percent as a stimulus to the industry.

Employment in the construction sector has declined since 1975 from an average of 44,600 to 32,200 in October 1977 , a decline of 12,400 jobs; that is almost 4 percent of the total labor force at that same date.

Tab1e II -37

Labor Force and Employment in Construction 1974-1977

\begin{tabular}{|c|c|c|c|c|c|c|c|c|}
\hline & \multicolumn{2}{|c|}{1974} & \multicolumn{2}{|r|}{1975} & \multicolumn{2}{|c|}{1976} & \multicolumn{2}{|c|}{1977} \\
\hline & Apr. & Oct. & Apr. & Oct. & Apr. & Oct. & Apr. & Oct. \\
\hline Labor Force * & 52,000 & 53,000 & 58,100 & 56,400 & 53,100 & 53,700 & 53,000 & 46,800 \\
\hline Numbers employed & 39,900 & 41,500 & 45,400 & 43,800 & 39,600 & 36,300 & 33,700 & 32,200 \\
\hline
\end{tabular}

* The Labor Force is comprised of: (a) persons currently enployed in the sector; (b) persons currently unemployed whose last job was in this sector.

Source: Economic and Social Survey. 


\section{TOURISM}

Introduction

Tourism is very important to the economy of Jamaica. The tourist industry normally competes with sugar for second place in the nation's earnings of foreign exchange, behind the bauxite/alumina industry.

The industry dates back to the late 19 th century and the Jamaica International Exhibition which was to be held in 1891. The Jamaica hotels law was passed in 1890 to encourage hotel construction and thereby provide visitor accommodation. The Government offered to guarantee the capital at $3 \%$ interest for all approved hotel construction. Later there were other incentive legislations and creation of special institutions all aimed at facilitating development of the tourist industry. The Hotels Aid Law, 1944, granted accelerated depreciation allowances and duty-free importation of materials for the construction and furnishing of hotels. The Hotel Incentives Law, 1968, and the Resort Cottages Incentives Act, 1971 provided tax holidays and other concessions.

The tourist trade had achieved real significance after World War II consequent on the increased material prosperity in the developed countries and the availability of cheap, fast air transportation. Jamaica benefited from the trade. The country not only possessed natural tourist assets but it was also close to the major North American urban population centers. The industry had potentials. 
Slowly, the growth in accomodation facilities outstripped the growth in visitor arrivals. Occupancy levels started to fall, financial problems set in and many hotels closed in the 1970's, some temporarily, some permanently.

In 1975, the Government decided to reduce incentives to developers under the Hotel Incentives Act 1968. The incentives would only be granted in exceptional circumstances. The Negril resort area was exempted. Construction was limited to replacement of obsolete rooms or until overall occupancy levels exceed 55 percent for at least two years. ${ }^{1}$

The industry is organized under the Jamaica Tourist Board. The Board is a statutory body under the Ministry of Industry, Tourism and Foreign Affairs and operates in the United States, Canada, the United Kingdom/Europe, and Jamaica. The Jamaica Tourist Board's budget has grown from under J\$400,000 in 1955 to over $J \$ 8,000,000$ in 1974 . This is calculated to be about 6.6 percent of the gross receipts from the Tourist Industry in 1974. Approximately 85 percent of the Tourist Board's advertising expenditure is spent in the North. American mainland attesting to the high concentration of the industry's market. In recent years the Jamaica Tourist Board has sought to diversify this tourist market through promotions in Europe. The grant for 1978-1979 is $\$ 1,406,845$.

${ }^{1}$ Statistical Yearbook of Jamaica 1977. (Department of Statistics, Kingston), p. 527. 
Performance of the Industry

In 1977 the Tourist Industry continued to experience the decline started since 1975. There was a steep reduction in visitor arrivals and the corresponding hotel occupancy levels. The deciine can be attributed to both internal and external factors.

Jamaica was affected by the recession in the developed countries as a consequence of oil price increases. This led to rising cost of living, job layoff, a fall in discretionary income and reduced demand for travel. World travel declined for two years, 1974 and 1975 .

Economic difficulties were experienced in Jamaica due to low production of the major exports-bauxite, sugar and bananas. This was further aggravated by the domestic social and political climate then existing in the island. The Caribbean Tourist Industry had been undergoing a period of unrest in the islands with an established tourist industry since the last 1960's. The economic deprivation of the masses of the region led to resentment of an industry designed for the wealthy, privileged few. ${ }^{1}$

Incidents of crime and violence increased. At about this time in 1972 , the new governmental regime won the elections and began expounding their doctrine of Democratic Socialism, Third World Solidarity, increased relationships with Cuba and imposed the new bauxite production levy in 1974. Tourism by its very

\footnotetext{
${ }^{1}$ Bank of Jamaica, Monthly Review, March 1979., p. 48.
} 
sensitive nature reacted almost instantly to the upsurges in criminal activities and the new ideological expoundings and the adverse publicity attendant on these factors.

In the United States trave1 to the Caribbean declined by 2.0 percent. In Jamaica the number of stop-over visitors declined for three consecutive years, 1975-1977. This is shown in Table III- 38 .

Table III -38

Stop-Over Visitors on Annual Basis

$\begin{array}{llr}1972 & 407,806 & +13.5 \\ 1973 & 418,257 & +2.6 \\ 1974 & 432,987 & +3.5 \\ 1975 & 395,809 & -8.6 \\ 1976 & 327,706 & -17.2 \\ 1977 & 264,921 & -19.2 \\ 1978 & 381,800 & +44.0\end{array}$

Cruise Passengers on an Annual Bas is

1973

1974

1975

1976

1977

1978
91,450

92,675

150,433

141,494

120,982

148,682
$+28.0$

$+1.3$

$+62.3$

$-5.9$

$-14.5$

$+22.8$

Source: Economic and Social Survey of Jamaica

The year 1978 saw an increase in all categories compared to 1977. The long-stay category increased by 115,300 arrivals and 
cruise passengers by 27,700 . This has been an upward trend in visitor arrivals which started in the last months of 1977 attributed to increased publicity expenditure and reduced adverse press reports. Total visitor arrivals for 1978 amounted to 532,900, an increase of 146,300 or 37.8 percent over 1977. ${ }^{1}$ Table III-39. gives total visitor arrivals for the years 1968-1978.

Table III-39

Total Visitors to Jamaica: $1964-1978$

1964

Total

1966

232,190

1968

345,288

1970

396,347

1971

414,720

1972

448,564

1973

493,488

1974

517,726

1975

530,726

1976

553,258

1977

470,714

1978

386,514

532,864

Distribution of Stop-Over Visitors by Country of Residence 1973-1978

\begin{tabular}{lrrrrrr}
\hline & 1973 & 1974 & 1975 & 1976 & 1977 & 1978 \\
\hline United States & & & & & & \\
of America & 77.8 & 78.4 & 75.2 & 70.0 & 67.9 & 66.4 \\
Canada & 8.8 & 8.7 & 11.8 & 14.8 & 16.0 & 18.8 \\
Europe & 6.4 & 6.3 & 6.7 & 8.4 & 8.8 & 9.1 \\
Other & 7.0 & 6.6 & 6.3 & 6.8 & 7.3 & 5.7 \\
\cline { 2 - 7 } & 100.0 & 100.0 & 100.0 & 100.0 & 100.0 & 100.0 \\
\hline
\end{tabular}

Source: Bank of Jamaica, Monthly Review, March, 1979,p.48. 
The national origins of stop-over visitors show Americans and Canadians accounting for over 85 percent of the total stopover visitors. However, there has been a decline in the percentage of Americans since 1974 and an increasing Canadian and European visitor market. The number of stop-over visitors is important as they are an indication of the overall demand for services and facilities in the industry, because it is this group that determines the "bulk of the income generating capacity" of the tourist industry. Cruise passengers, while spending an estimated average of about $J \$ 30.00$ on a one-day stop with an additional J\$10 per person from dockage fees, are like armedforce personnel. Their per capita expenditure is relatively small as they do not utilize accommodation facilities on iand. The number of hotel rooms available in the industry in 1977 was 9,119 , a net increase of 90 rooms or 1 percent compared to 1976 total of 9,024 .

The total number of available rooms for the years 1970-1977 is shown on the following page. 
Table III -40

Visitor Accommodation: $1970-1977$

\begin{tabular}{lrrrrrrrrr}
\hline ITEM & \multicolumn{10}{c}{ ROOMS } \\
\cline { 2 - 9 } & 1970 & 1971 & 1972 & 1973 & 1974 & 1975 & 1976 & 1977 \\
\hline Hotels & 5427 & 6116 & 6623 & 7499 & 8288 & 8366 & 9024 & 9119 \\
$\begin{array}{l}\text { Guest Houses } \\
\text { Resort Cottages }\end{array}$ & 1227 & 282 & 278 & 297 & 292 & 295 & 295 & $\mathrm{n} / \mathrm{a}$ \\
$\begin{array}{l}\text { Apartment } \\
\text { Houses }\end{array}$ & 124 & 282 & 323 & 206 & 147 & 147 & 149 & $\mathrm{n} / \mathrm{a}$ \\
\hline TOTAL & 7026 & 8129 & 9065 & 10,069 & 11,068 & 11,235 & 12,061 & $\mathrm{n} / \mathrm{a}$ \\
\hline
\end{tabular}

Change in Total Accommodation: 1970-1976 $=71.6 \%$

Source: (1) Statistical Yearbook - 1977

(2) Economic and Social Survey - 1977

Between 1970 and 1976 total visitor accommodation increased by over 5,000 rooms or 72 percent and for beds the increase is even more significant.

The increase in visitor accommodation in most cases outstripped increases in visitor arrivals. Furthermore, the industry suffers from seasonal fluctuations. The busy season is from December to April when occupancy rates are extremely high. The expansion of capacity seems to be geared to the size of the market in the high season. In the off-season period, in particular summer rates are reduced often as much as 40 percent to attract the budget conscious visitor with lower income. 
Since the last $1960^{\prime} \mathrm{s}$ there has been a downward trend in hotel occupancies, often due to increase in capacity and annual decline in visitor arrivals attributed in the past few years to the social and political climate in the Caribbean region and Jamaica. The occupancy rate is derived by expressing total occupancy, local and foreign, as a percentage of total capacity.

Dccupancy rates of around 50 percent is often felt to be enough to make an enterprise profitable although recent studies say the break-even point is 60-65 percent room occupancy rate. 1

The table below shows the downward trend in occupancy rates. 1978 estimate showed a remarkable upswing in Table III-41.

Table III-4I DOWNWARD TREND IN HOTEL OCCUPANCY RATE 1968-1977-JAMAICA

\begin{tabular}{lcc} 
YEAR & ROOM & BED \\
\cline { 2 - 3 } 1968 & 66.8 & 63.0 \\
1969 & 62.1 & 58.7 \\
1970 & 50.1 & 46.3 \\
1971 & 51.5 & 45.3 \\
1972 & 48.9 & 45.3 \\
1973 & 48.1 & 43.3 \\
1974 & 43.8 & 40.0 \\
1975 & 43.5 & 39.5 \\
1976 & 33.2 & 30.4 \\
1977 & 28.9 & 25.3 \\
1978 & 39.5 & 40.0
\end{tabular}

Source: Bank of Jamaica

The highest occupancy rates were experienced in Jamaica's newest resort, Negril which started operations in 1975. By 1976

${ }^{1}$ CADEC, The Role of Tourism in Caribbean Development, (Barbados, 1971), p. 42. 
it was experiencing occupancy of 44 percent compared to the al1island rate low of 33 percent. In 1977 it surpassed its previous record enjoying 67 percent room occupancy as against the a 11 -island rate of 29 percent.

In an attempt to improve occupancy levels Jamaica is being promoted as a year-around operation and not just a winter haven for the wealthy, at the same time to expand domestic tourism. A domestic holiday programme was established to encourage local Jamaicans to vacation 1ocally; thereby improving hotel occupancy, maintain employment and save foreign exchange. The Government made a provision of $\mathrm{J} \$ 3$ million to enable workers in the public service to utilize the domestic holiday programme. The programme boosted 10cal visitorship to over 131,000 visitors for 1977 . The table below gives the distribution of Jamaican guests in hotels for 1976 1977.

Table III - 42

NUMBER OF JAMAICAN GUESTS

IN HOTELS 1976-1977

\begin{tabular}{lcc}
\hline Area & $\begin{array}{c}(\text { Aug-Dec } \\
1976\end{array}$ & 1977 \\
\hline Kingston & 7,016 & 29,079 \\
Montego & 10,062 & 25,334 \\
Ocho Rios & 16,249 & 50,042 \\
Port Antonio & 5,850 & 12,998 \\
Mandeville & 4,049 & 8,303 \\
Negril & 886 & 5,337 \\
\hline TotAL & 44,112 & 131,089 \\
\hline
\end{tabular}

Source: Economic and Social Survey of Jamaica 
The steep decline in tourism for the two years 1976 and 1977 resulting in change in the ownership patterns of the existing hotels in the island. The seasonality of the industry was accentuated by the decline in visitor arrivals. The hotel occupancy levels for the island declined to a disastrous level of 28.9 percent in 1977 , approximately 30 hotels closed and hundreds of workers laid off during the year. The withdrawal of foreign ownership pressured the Government into expansion of state ownership into hotel infrastructure. An indication of Government ownership of hotels in 1977 is given below.

\section{Table III -43}

GOVERNMENT OWNERSHIP OF HOTEL ROOMS 1977

No. of Hotels No. of Rooms

Fully Government Owned 11 2,574

Shareholding by Government

4,252

Source: Economic and Social Survey

In 1971 thirty-five percent of the hotels in Jamaica were wholly foreign owned, 56 percent were wholly locally owned and 9 percent were joint ventures. ${ }^{1}$

Foreign ownership dominated the larger hotels, in the form of large American hotel chains. Internationally known hotel names

${ }^{1}$ Iserdeo Jainarain, op. cit.,p. 307. 
such as Hilton, Holiday Inn and InterContinental Hotels operate in Jamaica. By January 1978, foreign ownership had declined to 26 percent of total hote 1 rooms, or 2,323 rooms. 26 percent were owned by private entrepreneurs. ${ }^{1}$

Table III -44

OWNERSHIP OF HOTEL ROOMS AT JANUARY 1978

\begin{tabular}{|c|c|c|}
\hline A11 island & No. of Rooms & \multicolumn{2}{c|}{ Ownership } \\
\hline Local & Foreign & Local \\
\hline 6617 & 2323 & 74.0 \\
\hline
\end{tabular}

As a result of the expansion the state-owned company-National Hote1s and Properties Limited is in control of the 4,252 hotel rooms. This represents approximately $\$ 200$ million in investments and makes them the largest single hotel owner local1y.

The recent five-year plan has set various targets for the industry, in particular:

(i) To double foreign exchange earnings from tourism the target for 1978 is US $\$ 134$ million and this is to increase to US\$276.0 million in 1982 .

(ii) The achievement of 65 percent occupancy levels is landwide for the period - starting with a $40 \%$ occupancy in 1978 and increasing to $80^{\circ}$ occupancy in 1982.

(iii) To increase domestic tourism to 180,000 Jamaican vacationers by 1982 .

${ }^{1}$ Economic and Social Survey, op.cit., p. 172. 
(iv) Increase local content of tourism expenditures; The National Hotel Supplies Company will buy and stock local consumable items for use by hotels. (v) Upgrading tourism staff.

This is to be achieved by increased package tours and charters particularly in the low months, May, June, September, October and the installation of a central reservation system. There is a planned 1000 rooms of new hotels and an occupancy level target of 77 percent upon completion at the end of 1982 .

Contribution of the Industry

Tourism appears in the balance-of-payments account as an "invisible" service item, and its receipts are used to offset the age-old trade deficit in the merchandise section. The industry normally competes with sugar for second place behind the bauxite/ alumina industry in the islands earnings of foreign exchange. 1977 it maintained its number two position due to the depressed condition of the world sugar market. Estimates for the year 1978 show the same thing happened for that year.

Estimates of Tourist expenditures for the period 1972-1978 are shown in Table III-45. 
Table III - 45

RECEIPTS FROM TOURISM 1972-1978

(J\$)

\begin{tabular}{lccccccc}
\hline & 1972 & 1973 & 1974 & 1975 & 1976 & 1977 & 1978 \\
\cline { 2 - 7 } $\begin{array}{l}\text { Receipts } \\
\begin{array}{l}\$ \text { milion } \\
\text { Percentage }\end{array}\end{array}$ & 107.9 & 115.8 & 121.2 & 116.8 & 96.1 & $95.5^{*}$ & $223.6^{* * *}$ \\
\begin{tabular}{l} 
change \\
\hline
\end{tabular} & 15.8 & 7.3 & 4.7 & -3.6 & -17.7 & -0.6 & \\
\hline
\end{tabular}

* Basic Rate

** Inflated dollars due to devaluation

Source: Bank of Jamaica

The estimate for 1978 shows a significant increase over 1977. Its true value is much less as between January 1977 and December 1978, the value of the U.S. dollar increased from:

$$
\begin{aligned}
& J \$ 1.00=\text { U.S. } \$ 1.10 \text { to } \\
& J \$ 1.70=\text { U.S. } \$ 1.00
\end{aligned}
$$

The various devaluations over this period was constantly converting to the more Jamaican dollars compared to the period prior to the devaluations in April 1977.

A recent survey conducted in 1977 by the Tourist Board showed tourists were spending more in 1977 than in 1971. This is feasible considering the increased cost of vacations worldwide. The survey indicated that the stop-over visitor spent on an average U.S. \$48 per day in winter and U.S. \$41 in sumner.

Earnings from tourism as a percentage of the Gross Domestic Product has been on the decline since 1973. This is depicted in Table III -46. 
Table III -46

EARNINGS FROM TOURISM AS A PERCENTAGE

OF GROSS DOMESTIC PRODUCT

Year $\quad$ of G.D.P.

$\begin{array}{ll}1973 & 6.8 \\ 1974 & 5.4 \\ 1975 & 4.4 \\ 1976 & 3.4 \\ 1977 & 5.0\end{array}$

Source: Five-Year Development Flan, Jamaica

Preliminary figures for 1977 indicate that the contribution of earnings of tourism may have risen to almost 5.0 percent of Gross Domestic Product.

The following table gives the contribution of the major export items to total exports for the years 1972-1977.

Table III -47

\begin{tabular}{|c|c|c|c|c|c|c|}
\hline Items & 1972 & 1973 & 1974 & 1975 & 1976 & $1977^{+}$ \\
\hline Alumina & 119.0 & 147.8 & 343.5 & 346.9 & 276.8 & 343.3 \\
\hline Bauxite & 68.4 & 79.5 & 127.6 & 106.9 & 112.6 & 145.9 \\
\hline Bananas & 11.9 & 16.4 & 11.5 & 14.6 & 11.9 & 16.7 \\
\hline Sugar & 33.8 & 35.4 & 74.4 & 139.7 & 55.9 & 69.2 \\
\hline $\begin{array}{c}\text { Tourism* } \\
\text { (gross) }\end{array}$ & 107.9 & 115.8 & 121.2 & 116.8 & 96.1 & $95.5+$ \\
\hline other & 66.1 & 75.6 & 107.4 & 104.6 & 118.5 & $109.1+$ \\
\hline TOTAL & 408.8 & 470.5 & 785.6 & 829.5 & 671.8 & 779.7 \\
\hline $\begin{array}{c}\text { *Net Tourism } \\
\text { Receipts }\end{array}$ & 71.3 & 90.4 & 88.5 & 69.3 & 42.6 & 84.7 \\
\hline
\end{tabular}

+Basic Rate

Source: Bank of Jamaica, Quarterly Bulletin, March 1978

In 1973 it was estimated that about 66\% of every do11ar earned in the industry remained in Jamaica, that is, the retained expenditure of 66 percent. It is assumed today that this percentage 
is slightly higher with the reduced amount of foreign ownership and imported food items. The industry still consumes a large amount of imported foods and payments must be made abroad to promoters and commission agents. This is increasingly so as Jamaica diversified into package tours and increased charters.

In Jamaica the industry provided direct employment for 8421 in 1977, concentrated among lower hierarchial levels--the unskilled and females. Tourism employs only a small number of expatriates but they have effective control over the industry. Employment for 1971-1977 is shown below.

Table III- 48

EMPLOYMENT IN VISITOR ACCOMMODATION IN JAMAICA FOR 1971-1977

\begin{tabular}{|llllllll|}
\hline & 1971 & 1972 & 1973 & 1974 & 1975 & 1976 & 1977 \\
\hline TOTAL & 9,396 & 9,585 & 10,177 & 10,740 & 9,673 & 8,482 & 8,421 \\
\hline
\end{tabular}

Source: (i) Jamaica Tourist Board

(ii) Economic and Social Survey

There has been a decline in employment since 1974 from over 10,740 jobs to 8,421 at the end of December 1977 , that is, 1 ess than 1.0 percent of the total labor force. Compare this to an all-island recorded unemployment figure of 24 percent in 1977 . It's possible the actual figures could have been much lower as earlier in 1977 during the off-season months 30 hotels closed and hundreds of workers were laid off. However, there was a dramatic improvement in visitor arrivals in the last months of 1977 continuing into 1978. The employment figures were calculated at this high point in December 1977. 
Using a ratio of $1: 1$ direct to indirect employment overal1 employment could be 17,000 for 1977. Average annual income per employee was estimated to be $\$ J 3200$ per annum in $1977^{1}$ For those intermittently employed in craft production of souvenirs, the average per capita earnings is even much lower, less than half of the above figure.

Apart from the industry's contribution to net foreign exchange and employment, it should act as a stimulus to overall development. However, this is not usually so, it is an enclave virtually isolated from the rest of the economy. The pattern is that of an "international tourism style" highly dependent on imported managerial skills, food and beverages and even architectural designs. In recent years in Jamaica there has been a concerted effort to increase the domestic content of the inputs.

While it is possible for the tourist to isolate himself from the host society, the society does not have this choice. The host society must face the social cost and compare the economic returns with the "opportunity cost" of the capita1. In 1968 it was estimated that the average cost of bringing one room into operation was EC $\$ 33,600$ in Jamaica. Since then the cost had increased tremendously. This is an extremely high capital requirement per direct job, much higher than in manufacturing. In addition tourism requires additional investments in supporting and

${ }^{1}$ Employment, Earnings and Hours in Large Establishments, 1977. (Average weekly earnings of $\$ 56.16$ for a 42 hour work week.) 
ancillary services. Also in highly capital-intensive infrastructures--in airports, harbours, roads, telephone, water-supply and other utilities.

The industry in Jamaica involves the leisured enjoyment of specially maintained areas of natural island beauty by visitors with service provided by formally clad, often deferential Jamaicans. Tourism is a maturing industry prone to the ills of such industries-vicious competition and its corresponding reduced profit rates. Slowly, as the Tourist product becomes standardized among competing resort destinations to suit the mass market of package tours and charters the countries become interchangeable in the mind of the tourist and the ability of each destination to provide variety, novelty and strangeness decreases. 


\section{CHAPTER IV}

Tourism despite its glanour is just another industry with its own particular side effects. The major benefits of tourism such as foreign exchange earnings, contribution to employment and development are not ignored, but the aim of the chapter is to analyse the structure of the industry as it exists in Jamaica and its economic, social-cultural, political and environmental impacts. This include the dangers of over-commercialization of original hospitality, tourist densities, dependence and demonstration effects.

\section{CRITICISMS OF THE TOURIST INDUSTRY}

Tourism has often been likened to a new version of colonialism within post-colonial societies. The reintroduction of the rich, westernized elite in Third World developing countries and the obvious display of wealth in poor societies provides contrasts of race and affluence. The generalized myth of the prosperity of the tourists is not easily dispelled and is said to have created the so-called "demonstration effect" or confrontation effect." Exposure to the way of life of the tourist creates the desire to work harder, to achieve the level of education amono the local people to be able to emulate the tourists. As this desire becomes frustrated, hostility, and resentment set in. As Brian Archer stated:

-- "and especially when there is a considerable disparity of wealth between the indigenous population and the tourists, crime, prostitution, gambling and drug traffic may be imported into the 
holiday areas from other regions. Many of the social conventions and constraints imposed upon tourists in their home areas are absent when they visit another region and, in consequence, their moral behaviour can deteriorate without due censure. As a result many local people find that by catering for the several needs of their visitors, they themselves can achieve a relatively high level of prosperity." (1)

The "demonstration effect" extends to the elites and the mass of the middle class in the host society. They become even more material conscious:

-- "their eyes turned even more firmly toward the delights of the industrialised, consumer-oriented world. The Masses see the tourist both as a hated foreigner and a powerful symbol of the inequalities of our contemporary world." (2)

Much of the foreign exchange earned in the industry finds its way into the Black Market and thereby enables the elites to hold on to their privileges.

The Metropolitan agencies who sell tourism have been criticized for their "fantasy" images created of the Third World destinations and the rise of the "playground culture" and leisurely life styles as they are inimical to development for newly struggling, independent nations.

\section{STRUCTURE OF THE INDUSTRY IN JAMAICA}

Most of the large hotel complexes in Jamaica are managed either under straight management contracts, joint ownership

${ }^{1}$ Brian Archer, "Domestic Tourism as a Development Factor," Annals of Tourism Research; Volume V, Number 1; January/March 1978, p. 129.

${ }^{2}$ Louis Turner and John Ash, op. cit., p. 185. 
or lease arrangements with large international companies. In their own self-interest these international hotel chains prefer management contracts, leasing or franchising to equity participation as these arrangements reduce risks while increasing profitability, and achieving international expansion and prestige from being worldwide. The risks are calculated as a product of these factors; political stability, degree of inflation, history of nationalisation, economic growth, credit availability and currency convertibility. An international banker wrote of his experience in Jamaica:

-.-"after working closely with Hyatt and InterContinental in Ocho Rios, I am convinced that the major hotel chains are getting away with "absolute murder" in the industry. All of the costs of raising funds - capital and bank debt has been successfully pushed off onto the government with the "vague hopes" that the costs will be recouped in the lease contracts. While government funding and ultimate ownership could foster greater control over the industry, most of that control is abrogated in the lease contracts, anyway." (1)

Management contracts are usually preferred to franchises because the level and quantity of expertise to operate an international hote 1 is regarded as 1 imited in the host country and the indigenous management is felt to be incapable of managing. These international hotel chains are usually well-established in their home countries with a track record of success in provision of services for the tourist in those destinations the tourists have shown preferences for. The hotels are predominanty

${ }^{1}$ Andrew Harris, First National Bank of Chicago, personal 
resort hotels - for pleasure, located in urbanized areas with the amenities required, and an average room size of around 100 rooms.

The Multi-National Hotel Chains are needed even though one is aware of their disadvantages such as their unfavorable accounting practices - their use of transfer pricing, overstatement of costs and understatement of earnings, and their technical expertise in negotiations compared to the local civil servants and politicians. Often the agreements concluded are detrimental to the country and the fees charged for managerial and technical assistance are exorbitant. These hotel chains tend to keep to themselves their best personnel in those hotels where they have a self-interest, in terms of equity involvements, or higher profitability and ease of currency convertibility. At the same time the level of expertise required in effect reduces the role of the Jamaicans to the unskilled laborer and their training for $10 \mathrm{ca} 1$ executive positions leaves much to be desired.

The expansion of these International Hotel Chains in Third World Tourist destinations like Jamaica is yet another market outlet for American goods, witness the U. S. Department of Commerce report on tourism growth in Trinidad; the department stated:

"The tourist activity will create a further demand for hotel and restaurant equipment that offer an opportunity for American suppliers of hotel furnishings, electrical and air-conditioning installations, refrigeration equipment and swiming pools. In 
addition, American food product lines will be necessary to supply the North American tourists expected to fill these new hotels." (1)

The industry has a strong propensity to import. Those in control want a liberal import policy to import what they want. This seems to imply that those domestically produced imputs - food, drink, construction materials, furniture and manpower are inferior. Often the type of technology used in the industry requires further importations of both specialized maintenance equipment and technicians.

Advertisements are prepared by American firms. In 1977 the advertisement budget of Jamaica was $\$ 2-2.5$ million. ${ }^{2}$ Often the image portrayed is not one of the most desired and a limited presentation of the country can result in an incomplete picture of the country for potential tourists. They are limited to the range of choices presented and will seek to experience only those.

$1_{U}$. S. Department of Commerce, "World Trade Outlook for Latin America and the Caribbean", Overseas Business Reports, December 1970 , p. 5.

${ }^{2}$ Robert Alan Britton, "International Tourism and Indigenous Development objective: A Study with Special Reference to the West Indies", University of Minnesota, Ph.D. $1978, \mathrm{p} .44$. 
Table IV -1

U.S. Media Expenditure and Cost Per

Visitor ${ }^{(a)}$ for ${ }^{(*)}$ Selected Caribbean

Island, 1976

\begin{tabular}{lcccc} 
State & U.S. Arrivals & & Expenditure & $\begin{array}{c}\text { Expenditure per } \\
\text { U.S. Visitor }\end{array}$ \\
\cline { 2 - 2 } Bahamas & $750,000^{(b)}$ & & $2,426,000$ & \\
Jamaica & 229,000 & & $2,064,000$ & 93.23 \\
Dominican Rep. & 181,000 & 94,000 & .01 \\
Barbados & 56,000 & 195,000 & 3.48 \\
Trinidad \& Tobago & 39,000 & 233,000 & 5.97 \\
Curaco & 33,000 & 172,000 & 5.21
\end{tabular}

* (a) Not including cruise or transit passengers

(b) Estimate

Sources: ASTA Trave1 News, Trave1 '77/'78: The Big Picture, pp. 47, 48, 78; The Caribbean Tourism Association, Visitor Statistics, 1976.

Dependence on Tourism corresponds with vulnerability to fluctuations in the economic cycles of the main tourist generatingeconomies, that is the United States and Canada. Add the seasonal nature of tourism and its sensitivity to changes in fashion and taste and the problem of dependence is even more insurmountable. Witness the disastrous effects of planning and construction of increased hotel rooms in the period of optimism and completion in the lean years. Islandwide hotel room and bed occupancy dropped to an all-time 1ow, many hotels closed, some permanently, some temporarily, and hundreds of workers laid off. Often the Government is left with the responsibility of protecting employees from loss of jobs. Dependence on the use of foreign 
capital, technology, imported goods and manpower also raise the question of sovereignity and domestic control.

Destination places have historically been subjected to the tastes of the visitors. As Stanley Plog stated in his paper "Why Destination Areas Rise and Fall in Popularity":
"We can visualize a destination moving across the spectrum, however gradually or slowly, but far too often inexorably towards the potential of its own demise. Destination areas carry with them the potential seeds of their own destruction, as they allow them- selves to become more commercialized and lose their qualities which originally attracted tourists." (1)

The often-stated benefits from devaluation is short-sighted as the country ends up paying more for the imported inputs and local prices are adjusted upward to compensate for increased costs. Devaluation also adversely affects the domestic tourist market who must pay more although their salaries have not appreciably increased.

The industry boasts of tourism's possibility as a development strategy yet the minute they are asked for a contribution, witness their resentment:
"The Caribbean hotel industry's gross operating profit is far and away the lowest in the world, basically because island governments expect and to varying degrees make the industry subsi- dize social needs often unrelated to the industry, in order to raise the local population's standard of living--unless the hotels stand together, the governments will divide and rule."
(2)

Istanley C. Plog, "Why Destination Areas Rise and Fall in Popularity", paper presented at a meeting of the Southern California Chapter of The Travel Research Association, 10 Dctober 1972, p. 5 . 


\section{THE ECONOMIC IMPACT}

The economic benefits of Tourism are threefold: the earnings of foreign exchange, the multiplier effect of the tourist expenditure within the economy, and employment. Tourism was the second largest earner of foreign exchange in 1977 behind the bauxite/alumina industry, but ahead of sugar grossing $J \$ 95.5$ million. The net receipts of visitor expenditures to Jamaica and expenditures of Jamaicans abroad was on $1 y$ J\$84.7 million in 1977. As Turner and Ash wrote:
"A number of illusions about the economics of tourism need exploring. First, just because a tourist spends a dollar in a country there is no guarantee that it is going to stay there. In large parts of the tourist world, many of the hotels and restaurants are foreign owned, so part of the tourist dollar flows out inevitably in the form of profits or dividends; many of the top managers are expatriates, who, as well as being paid more than local employees, will tend to bank a good part of their salary out of the country; much of the food and drink may have to be imported to meet the conservative tourist palate,.............. the tourists demand expensive machinery like air-conditioning, 1ifts, speed boats and cars, al1 of which will have to be imported"........ (1)

It was estimated in 1973 that Jamaica had a leakage of 34 percent. Newspaper reports suggest between 60 and 80 percent 1eakage. ${ }^{2}$ Today it is expected to be reduced due to the restrictions placed on importation of food and consumer durables, and increased local ownership and participation in the industry.

\footnotetext{
${ }^{1}$ Louis Turner and John Ash, op. cit., p.116.

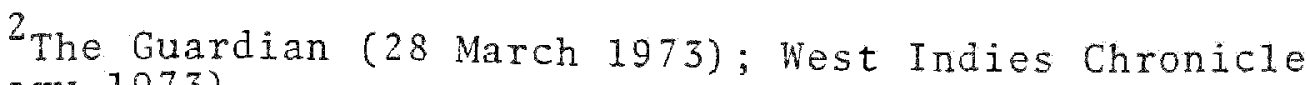
(February 1973). 
Where a foreign airline or charter is used, a large proportion of the total money spent by tourists for the holiday will never reach Jamaica as it is spent on transportation to and from the island. Also Travellers' cheques and credit card schemes are all administered externally in the tourist-generating countries and commissions have to be paid - and this further complicates the enforcement of exchange control regulations.

The black marketing of currency and the settlement of tourist expenses by local residents deprives the country of the needed foreign exchange. However insisting on a minimum foreign exchange expenditure per tourist day can alienate visitors and thereby be counter-productive.

The high degree of leakage including the cost for intermediate goods imported such as fuel for electricity enters the calculation and has the effect of reducing the multiplier effect of tourist expenditure.

John Bryden's report on the economics of tourism claims that tourism kills both export-oriented and domestic agriculture. Increased visitor arrivals is accompanied by increased imports of everything, food included and traditional agricultural exports decline. He states there is little evidence that the wages paid to the unskilled and semi-skilled is any higher than in the fields. After analyzing possible alternatives, he concludes that the returns on investments in hotels are very low, depending on the extent of foreign ownership, number of expatriates employed and where the 
money was raised. Peasant farmers are displaced, inflation increases and property values increase beyond the reach of the local people. I
"Tourism depends on resorts, which are built for the benefit of foreigners,..........., because the industry is modern and glamorous, and there are some jobs which pay better than traditional ones, everyone drops tools and rushes to serve the foreigners, The locals build the resorts and serve in them, which, if fully controlled by foreigners, will contain few really worthwile jobs. In the meantime, the fields return to weeds; the locals lose their traditional skills; they lose their ability to produce anything." (2)

Tourism tends to draw on the unskilled agricultural labor force, thereby increasing rural-urban migration.

There are additional problems of lack of confidence in locally produced foods. Local hoteliers and chefs are believers of the myths that visitors desire only international cuisines and accommodation. Lundgren found that the large resort hotels in Jamaica made purchases from small suppliers - 59.2 percent of all large hotel food transactions were from small growers but the purchases accounted for only 14.6 percent by value. 3 In 1977 out of a total population of $2,096,800$ only 8421 persons were employed in the Industry for the month of December

${ }^{1}$ John Bryden, Tourism and Development: A Case Study of the Commonwealth Caribbean (Cambridge: Cambridge University Press, 1973)

${ }^{2}$ Louis Turner and John Ash, op. cit. p.123.

${ }^{3}$ Jan Lundgren, "Tourist Penetration/The Tourist Product/ Entrepreneurial Response", Proceedings of a meeting of the International Geographical Union 's Working Group on the Geography of Tourism and Recreation (Peterborough, Ontario: Department of Geography, Trent University, 1975), p. 66-67. 
1977 , a high point in the winter 1977-1978 tourist season. Expatriates accounted for less than 1 percent of those directly employed in Jamaican accommodations in $1975^{(1)}$ but wherever they were they had effective control. There are stipulations about employing Jamaicans but nothing on how this is to be structured.

In addition to revenue leakage, a low multiplier and competition for labor there are other negative economic factors to consider such as the cost of tourism - infrastructure, competition for land, excess capacity of tourist facilities and increased balance of payment problems.

The cost of providing and maintaining the infrastructure is not borne equitably due to the granting of tax holidays and other incentives. The hotels facilities build are also energyintensive.

Competition for land causes increased land prices and speculation. The seasonal nature of the industry can cause inflationary price pressures which are felt more intensely by low income groups.

Overbuilding and tourism's seasonality results in excess capacity and low annual occupancies for all concerned. Between 1970-1977 the number of hotel rooms in Jamaica increased from 5427 to 9119 available rooms, that is an increase of 68 percent.

IPeter Goffe, "Development Potential of International Tourism", Corne11 Hote1 and Restaurant Administration Quarter1y $16: 3(1975: 29$. 
For the same period, room occupancy fell from 50 percent in 1970 to 29 percent in 1977. Occupancy is indicative of the financial stability in the island's hotels. The Caribbean region ranked lowest in occupancy rates; lowest in gross operating profits on a per room basis at $\$ 903$; when world average was $\$ 3566$. At the same time the region had the highest operating expenses, at $\$ 5259$; paid the most for travel agents' commissions relative to room sales, advertising and promotion, administrative and general costs; had the second highest repairs and maintenance outlay and the second highest ratio of payroll and related expenses to hotel sales. ${ }^{1}$

The increased demand for imported goods spurred on by the additional income and exposure to the tourist is in excess of the island's capacity to import. Also the presence of tourist stimulates the demand for foreign travel. The total effect is to increase balance of payment deficits.

\section{THE SOCIO-CULTURAL IMPACT}

Any analysis of the impact of tourism should consider both the economic and the non-pecuniary effects. However the noneconomic impacts of tourism are not easily quantifiable as it is difficult to assign a dollar to each of tourism negative or positive aspects. The tourist brings the needed convertible currency but not without a cost to Jamaica. It bestows benefits

${ }^{1}$ Robert Britton, op. cit., p. 246. 
at the same time that it exacts a cost. The cost is the unexpected sacrifices and compromises the society has to make.

Even developed societies, although more resistant experience tourism's negative impacts. ${ }^{1}$ Every year miliions of tourists converge on the large metropolitan cities of New York, London, Toronto but they are easily absorbed within the system and merge with the local populace. ${ }^{2}$ on a small island like Jamaica, too many tourists can overwhelm the country and the people. The degree of dislocation is related to the ratio of visitors to 1ocals. In 1977 when tourism was at its lowest ebb, there were only 386,514 visitors to Jamaica. The population was estimated at that date to be $2,096,800$, which gives a ratio of about $5: 1$ locals to tourists. This was reduced to $4: 1$ locals to tourist in 1978 when visitor arrivals totalled 532,864, that is a density of 121 visitors per sq. mile. The ratio of tourists to locals is much higher than the all-island average in the resort areas of Montego Bay, Ocho Rios and Negril.

The tourist density in Jamaica is not as high as that of the Bahamas which had a population of 185,000 and tourist arrivals of 1.4 million in $1975^{(3)}$, or the U. S. Virgin Islands with a total land area of $132 \mathrm{sq}$. miles, population of 80,000 and tourist arrivals of 1 million in 1972, or Barbados where there are 2,110

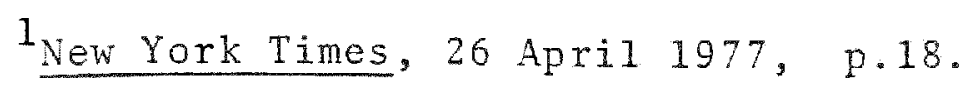

${ }^{2}$ Donald Lundberg, "Caribbean Tourism Part II - Social and Racial Tensions", Cornel1 Quarterly, May 1974, p. 82-87.

${ }^{3}$ Somerset Waters and William Patterson, SSTA Travel News: The Big Picture 1976 (New York, Trave1 Communication 1976), p. 42 . 
visitors per sq. mile. ${ }^{1}$ In these cases tourist arrivals outnumber the local population which often gives rise to resentment by locals towards visitors.

Even when the tourist does not differ from the locals racially, as in the case with Black American visitors to Jamaica and the Caribbean, they nevertheless differ in speech, culture and social customs.

\section{TOURISM CAUSES SOCIAL TENSIONS}

The typical tourist is in Jamaica to escape his highly urbanized culture. He seeks the simple, exotic life portrayed in the advertising promotion conceived in his own country. He desires to enjoy himself forgetting the pressures of his middleclass world he has just left as well as the economic social and environmental realities of the island he is visiting. He demands certain standards of accommodation, food and service. Gradually his Euro-American values are superimposed on the Jamaican society with its historical background in colonization, slavery and Independence.

Social tensions are inevitable. The workers in the menial hotel jobs are exposed to guests carrying as much money in their pockets as they will make in one or two whole years. According to Lundberg he cannot understand, why, if there is, justice is he not wealthy ${ }^{2}$ Unlike the visitors they cater to, the possibility

${ }^{I}$ Geoffrey Wal1 \& Inshan M. Ali, "The Impact of Tourism in Trinidad " Tobago", Annals of Tourism Research, Volume V, Oct./ Dec."79, p.45.

${ }^{2}$ Donald Lundberg, op. cit., p. 85 . 
of them taking such an escape is remote. The result is that they scheme ways to separate the visitor from some or all of his monetary of material possessions. This may take many forms such as supplying the tourist needs for entertainment, drugs or even outright theft of the tourist's belongings.

\section{TOURISM CAUSES A DECLINE IN LOCAL CUSTOMS}

Tourism slowly displaces the original local culture, evidenced by the preference for the materialistic and acquisitive values of the tourist and his consumptive pattern, called "champagne stomachs in beer pockets society" - the tourist model is not the most beneficial for a newly independent nation struggling to hold its own. The model displayed is one of overindulgence - in sun, fun, sex and drug; unaccountability and illusory wealth. The moral values of the tourist deteriorates, once they are out of the eyes of censor of their society. This has numerous implications for those urbanized pockets of Jamaican soeiety where tourist abound. The pattern of sexual behaviour begins to resemble that of more developed societies where morals are less rigid. Also increased acceptance of marijuana, hashish, cocaine and soft drugs develops. A taste of "hedonism".

In Jamaica, where the majority of visitors speak the same language as the native Jamaican--English--there is a tendency among hotel workers and people of the resort community to try to adopt the visitors' accents, slangs and manner of speech. After a couple of years of catering to the tourist trade, slowly the tourist attractions and facilities are standardized. 
Due to the difficulties of satisfying a continuous stream of tourists particularly during the peak season, it becomes necessary to offer a uniform tourist experience. The tourist exposure is thereby limited to few standard elements and cultural richness and spontaneity is reduced. The original hospitality becomes over-commercialized and goodwill declines.

Proponents for the industry are willing to cite ways in which tourism has increased folklore, artistic and cultural awareness. However the cultural exhibition deliberately put on for the benefit of the tourist reduced its inherent value to the performers. Often the performances are altered - either exaggerated or condensed to live up to the expectations of the visitors who seldom like the authentic culture and prefers his own concept of what he thinks it is.

- "By making it part of the tourism package, it is turned into an explicit and paid performance and no longer can be believed in the way it was before. This commoditization of culture in effect robs people of the very meanings by which they organize their 1ives."

Tourism has the similar effects on the production of portable souvenirs. The products are modified and standarized to suit tourist taste and concepts of what they should look like.

${ }^{1}$ Davydd Greenwood, "Culture by the Pound: An Anthropological Perspective on Tourism as a Cultural Commoditization", paper presented at the 73 rd Meeting of the American Anthropological Association, Mexico City, 19-24, November 1974, p.12. 


\section{TOURISM CAUSES CLASS TENSIONS}

Tourism increases tension between the classes, heightens the distance between the privileged and underprivileged in the society. At the bottom of the job hierarchy are the underprivileged. This gradually gives way to the privileged class and finally the expatriates at the very top. Associated with this hierarchy is the change from black to brown and finally to white.

In the eyes of the rural poor and urban masses, the tourist "glass palaces" are predominantly built to accommodate, by their humble standards - the wealthy North American foreigners and the nouveau riche national elite. There is a tendency among the national elite to identify with the tourist and as mentioned before the foreign currency derived from the industry provides a guarantee for them to hang onto their bourgeois taste of:

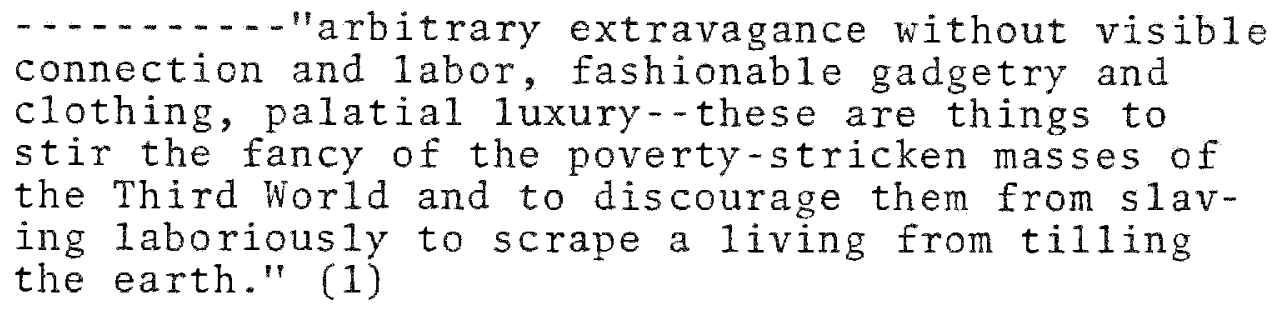

As previously mentioned tourism adds fuel to the rural-urban drift - and thereby decreases the possibility of Domestic selfsufficiency and social change. Census data on Jamaica during the 1960 s when tourism development was rapid show a considerable

IJacques Bugnicourt, "Tourism-The Other Face", Development Forum 5:6 (1977):8. 
number of migration from agricultural areas to tourist resort areas. It was estimated that about 75 percent of the 4000 workers employed in the Montego Bay Tourist industry might have migrated from the interior agricultural sector. ${ }^{1}$ This migration leads to overcrowding and pockets of unemployment and the resulting social problems connected with this type of development - harassment of tourists, juvenile delinquency and crime.

Associated with this migration is prostitution in the resort areas. Although tourism is not the cause of prostitution it has nevertheless increased the demand and supply for this type of service. It becomes very important that venereal disease in resort areas be monitored closely. Today there are strains of gonorrhea, resistant to penicillin which can do great damages to the residents in the small resort communities.

\section{POLITICAL IMPACT}

Since Independence in 1962, political power has shifted from the British Colonial masters to the present local politicians. Due to tourism's sensitive nature and vulnerability to changes in tastes and fashion of the consuming public it becomes necessary to subdue and restrain political debate and certain social changes rather than risk losing the major North American conservative market. Also, the easy flexibility among Caribbean destinations

${ }^{1}$ Headley Brown "The Impact of the Tourist Industries on the Agricultural Sectors: The Competition for Resources and the Market for Food Provided by Tourism", Unpublished research paper, National Planning Agency, Kingston, Jamaica, 1975, p.7-10. 
point to the need to present a balanced political, social and cultural front. The Jamaican industry has only recently started to recover from the blows dealt in 1975 and 1976 by adverse publicity in the North American tourist markets as previously mentioned in chapter III. The turn-around has not only been timely but achieved at a great promotional cost to Jamaica. Jamaica in addition to catering to tourist whims has to court the tour operators and tour packers. The tour operators have a similar influence on the island as the manufacturer of a food product has on the chain store which ultimately sells its products. They hold all the cards as the customer seldom knows exactly what he wants to buy and prefers to shop in a store which gives him a range of brands (as in the case of food) or destinations (as in the case of tourism). 1

Often the need arises for implementing certain restrictive policies for the economic or social good of the island, but consideration of the consequent negative effect on the Tourist Industry results in less effective compromises being adopted or exclusion clauses included. Witness the demand for a liberal import policy for goods and services by those in the industry when local indigenization of the industry to increase its contribution to the economy is urgently needed or the need to crush the drug traffic for fear of discouraging the younger tourist traffic or even the implementing of measures to reduce trafficing in foreign currency for fear of discouraging visitors.

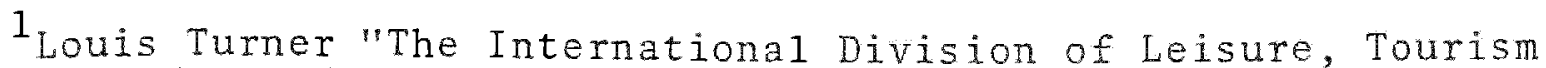
and the Third World", Annals of Tourism Research, Volume IV, No.1, September/october $1976 ., \mathrm{p} .17$. 
There is also the additional problem of Dependence and Sovereignity. Dependence on the tourist dollar translates into dependence on the buoyancy of the North American economies and therefore susceptibility to their economic fluctuations of recessions and inflation. Jamaica thus imports these conditions into an island already feeling the blows of underproduction, under-employment, devaluation and runaway inflation, and migration of the skilled and entrepreneural class.

\section{ENVIRONMENTAL IMPACT}

Generally the environmental effects are unmeasured and hard to assign a monetary value. Nevertheless the environment needs to be protected in order to retain its beauty. The architectural design of the hotel facilities imitates that of Miami Beach, and is not built to make maximum use of the local climate. These "many-storied glass palaces" not only block residents' views of the sea but also the inland movement of the sea-breeze and its cooling effect. Often waste and sewerage from these large structures are discharged in an unprocessed form and can pollute the surrounding sea. This is to the detriment of the marine life and those individuals who depend on fishing for a livelihood or a source of protein. Another effect is the depletion of ground water through overconsumption; soil and coastal erosion caused by removal of sand for use on beaches, and the removal of marine grass and clearing of mangrove areas. 
The decision makers on the island are reluctant to adnit to the numerous tourism-induced problems. They devoutly believe that the foreign exchange gains more than balances the costs of tourism. All the emphasis is placed on making the local people more friendly and welcoming to the visitors through the various local advertising conditioning and campaigns embarked on, while seeking to increase tourist arrivals through increased promotional expenditures.

Increased visitor arrivals is only a part of the solution, a decision has to be made on the type of tourist market most beneficial to the economy in terms of length of stay and average expenditure. 


\section{CHAPTER V}

\section{SUMMARY AND CONCLUSIONS}

This paper has attempted to present the scope of international tourism and its relevance to the developing nations of the Caribbean and Jamaica in particular. It has sought to establish the contributions of the major productive sectors including tourism to Gross National Product, foreign exchange earnings, employment and overall development of the Jamaican economy and it also discusses the major negative aspects of tourism. Its aim is to conclude whether tourism is the answer to Jamaica's developmental problem and whether tourism's negative impacts can be reduced and its effective contributions increased.

Chapter I reviews the history of tourism as it exists today in the 20 th century with widespread use of airplanes and automobiles. It followed tourism's development through the tropical regions of the world and the change from "sun-shunnilg" to "sun-worshipping" by the leisured class. It discusses the present trends in International Tourism, which is now the secondlargest item in world trade accounting for over 245 miliion international tourists globally and expenditures of U.S.\$50 billion in 1977. Tourism's fantastic growth has been the result of several factors: constant increases in disposable income and leisure time in developed societies; technological advancements in travel methods and accommodations, mass marketing, competition 
among destinations to welcome tourists, higher education and changing lifestyles. It is expected that international tourist arrivals will reach between 250 to 280 million by 1980 out of a global movement of between 780 to 1,050 million arrivals throughout the world. This indicates that the pace of tourism growth may yet be greater if travel predications are correct. Internationa1 Tourism is big business, a mass production activity.

International Tourism has displayed its ability to withstand economic fluctuations as seen during the worldwide recession of 1973-1974. By 1975 International Tourism had recovered once more, to within I percent of the 215 million arrivals in the prerecession year 1973, while at the same time Domestic Tourism in each country was increasing. In fact the recessions did not damage tourism, it only changed its structure. People merely chose to take vacations closer to home, chose less expensive accommodations and ate more cheaply.

This feature of tourism is important when one considers the impending recession consequence on the present worldwide fuel crisis. One can foresee a shift to destinations closer to each tourist-generating country. This can be to the benefit of the Caribbean Islands, close in proximity to the North and South American Continents.

The five critical factors adversely affecting major shifts in tourist traffic were recounted, they are: 1) different currency values; 2) different rates of inflation; 3) increased airline fares; 4) political disturbances; 5) economic recessions in the developed countries occurring simultaneous 1 y. 
Next the world pattern of tourist movement was discussed. Approximately one dozen countries generate four-fifths of al1 tourists. Arrivals were likewise concentrated to the nations of Western Europe and North America. Domestic Tourism however far surpasses international tourism. Out of a total expenditure of $\$ 70$ billion spent by Americans for domestic and foreign travel (the largest source of international travellers) foreign travel accounted for only $\$ 9.5$ billion.

The Third World nations together collect about one-fifth of total tourist expenditures, but almost 50 percent of this is accounted for by two countries: Mexico and Yugoslavia.

A definition of a tourist is also given and the four basic motives for travel identified - 1) physical motives relate to desire for rest, relaxation, recreation; 2) cultural relates to the desire to learn more about the world; 3) sociological involves travel for the sake of overcoming boredom in economically developed societies; 4) status - prestige involves keeping up with the Joneses and "one-upmanship". The factors determining the ultimate choice of a destination are recounted in particular the travel agents' recommendation. The prospective tourist is preoccupied with three factors: cleanliness, safety and reliability.

In Chapter I the commonalities within the Caribbean are discussed, these are location, climate; temperature, history of colonization, slavery, emancipation, immigrant labor, similarity of soil conditions, and crops. The islands of the Caribbean 
are small, densely populated with a history of emigration and its consequent adverse effects. Nevertheless the islands speak different native languages, have different political, economic and cultural structures, the result of their various colonial regimes - British, Spanish, French or Dutch. This explains the present absence of cohesion and the system of fragmentation.

The Caribbean, since the discovery has undergone very little structural change - the economies are still - 1) primary producers of raw materials to the developed countries; 2) dependent on external decision-making, imported manpower, technology, and raw materials; 3) possesses a very inadequate domestic agricultural sector; 4) growing unemployment. The mainstay of their economies are agriculture and tourism.

A discussion of Jamaica follows. An island of 4,244 square miles and is located approximately 100 miles southeast of Cuba and 100 miles west of Haiti. Jamaica is "a long jagged spine of.mountain set in a ring of plains", with the Blue Mountain rising to 7,402 feet above sea-level and more than half of its surface above 1,000 feet above sea-level. Only 20 percent is flat compared to other west Indian islands which are almost totally flat. Over 50 percent of the land is composed of Iimestone which is no good for agriculture thereby further limiting land for agriculture, Jamaica's foremost employer of unskilled labor. 
In 1977 Jamaica's population was estimated to be 2,109,400 of which 53 percent. were under 19 years and a total of 75 percent under 40 years old in 1976. Jamaica has been heavily dependent on emigration abroad to reduce its population land pressures, recorded migration exceeds 20,000 per annum, that is 1 percent of the tota1 population. Between 1950-1960, the exodus was to Britain but recently the movement is to Canada and the United States. Alas, the pattern has changed from being mostly unselective as in the case of Britain to be heavily skewed towards the skilled and professional qualified as regards North America. In effect, Jamaica becomes burdened by a greater proportion of the very young and old, both of which require a higher level of social services without some commensurate social contribution. In addition it deprives the country of leadership and an adequate return on the investment in the education of those Jamaicans who later migrate.

Jamaica suffers from similar ailments as all the other Caribbean territories, lacking land space, limited natural resources, skilled manpower and having a very fast growing population. However being the third largest island in the Caribbean, it still has much more land space capable of productive use, more rainfall and fast flowing rivers due to the mountainous interior and underground water for irrigation purposes. Most importantly Jamaica has Bauxite, the aluminous red earth which is the island's major foreign exchange earner. It also has a light manufacturing sector heavily dependent on imported raw materials and finally, Tourism. 
The reasons behind tourism's development in the Caribbean are then explored. Tourism seems tallored for the developing countries in the Caribbean. Governments of these islands possessing abundant supply of sun, warm climates; physical land and people constraints have opted for tourism hoping; 1) to revive their decadent sugar-cane producing economies; 2) to serve as an impetus for development of other industries; 3) to act as a cultural-political bridge between the developed tourist-generating economies and their individual countries.

Tourism's development is seen as having "a short gestation period" and can produce revenues within two years after a strong advertising campaign. It is a way of earning urgently needed convertible currencies required to reduce balance of payment deficits caused by increased demand for imports and reduced exports of primary commodities. Tourism promises maximum use of the unskilled and reduction in unemployment. The demand for international tourism is more stable than commodity trade. Tourism's market potential is good compared to commodity trade, the markets are not as protected therefore more easily accessible.

The thrust of the promotional efforts are directed at the developed Western markets with high standards of living, high rates of economic growth and a developed mass media - the U.S.A., Canada, Federa1 Republic of Germany and Great Britain.

The Caribbean region was further aided by its; 1) accessibility to its markets, there are regular scheduled flights from 
North America; 2) the relatively cheap airfare cost; 3) plentiful accommodation at varying "price ranges; 4) variety of other attractions offered - such as night-life, duty-free shopping, water sports and cultural entertainment.

Tourist arrivals in the region has increased annually by an average of 9.1 percent and for the years 1974-1977 which saw a world recession and recovery, arrivals showed an even higher rate of increase. However the increase in tourist expenditures has not kept pace with the increase in arrivals due to the tourist's success in economizing costs and shorter stays. Jamaica, however, registered a decline in stop-over visitors, tourism receipts, and its contribution to the Balance of Payments.

Travel agents play an effective role in directing tourism flows, therefore the survey of U.S. travel agents attitudes towards destinations in Latin America and the Caribbean was discussed. The agents were slightly more favorable towards the Caribbean than Latin America, but both regions were perceived to be remiss in providing for the personal and property safety of visitors. Mexico emerged as the OAS region most favorably positioned attitudinally. Mexico receives a third of all Americans vacationing outside the U.S.A.

The personality of a typical visitor to the Caribbean is explored. He is escaping his own world of anxieties and frustrations and is not interested in the social and economic issues of the small island nation sold to him as the place to go by his travel agent or the island government's tourist office in his 
home country. Anything other than his expectations makes him feel cheated and angry.

Chapter III presents data on the performance of the Jamaican economy in recent years, the adverse balance of trade, balance of payment deficit, reduced foreign exchange earnings and capital inflows and depleted foreign exchange reserves. The government policy of reducing imports and outflows of foreign currency were recounted. Also the incentives given to local producers to increase output for local consumption and export. The numerous devaluations demanded as a loan condition by the International Monetary Fund was mentioned. The devaluations were also expected to give a boast to the non-traditional exports as traditional exports are sold under prearranged trading agreements.

Overall there has been a negative real growth of 11 percent between 1972-1977, and the distribution of real income has also fallen considerably since 1971. Of 13 industrial sectors only three sectors, Agriculture, Mining and Transportation registered a real growth increase in 1977. Despite a decline of over 5 percent in output, the manufacturing sector was nevertheless the major contributor to the Gross Domestic Product. It was followed by the Distributive Trade in second place, Producers of Government Services, third, and the Mineral Industry in fourth position. Tourism contributing approximately 5 percent to the Gross Domestic Product ranked about ninth or tenth in 1977. 
Provisional figures for 1978 show there was even a greater surge in imports, which increased by over 60 percent of the 1977 total while exports increased by a lower figure of 55 percent, a consequence of the devalued Jamaican dollar as against the U.S. dollar standard on the world market. In 1977 food and consumer goods accounted for 13 percent of total imports, raw materials including fuel for 65 percent and capital goods - 22 percent.

Total foreign debt has increased and Jamaica's net foreign reserve took a negative plunge to $\$ J 405$ miliion in March, 1979.

Food exports made up on $1 y 16.6 \%$ of total domestic exports in 1977, falling from $23.5 \%$ in 1975, and crude materials composed mainly of bauxite and alumina accounted for over 71 percent followed in third place by export of beverages and tobacco 3.7 percent.

Jamaica's economy is heavily dependent on six industrial sectors and five of the most important sectors - agriculture, mining, manufacturing, construction and tourism are examined for their contribution to the gross domestic product, foreign exchange earnings, employment and overall development.

Agriculture including commercial forestry occupied 55 percent of Jamaica's total land area. Land division still follows the earlier plantation system of few large estates and a large peasantry. Less than one percent of all farms accounted for more than half of all farm acreage and were of the best and most fertile agricultural lands. Farms under 25 acres made up 
98 percent of al1 farms. Also the land use pattern is very haphazard and does not follow any specific plan aimed at optimum use of the limited land resources.

The two major export crops, sugar and bananas occupy the most fertile alluvial coastal plains, over 252,000 acres, 21 percent of the land classified as suitable for agriculture. However increasingly the value of sugar and bananas for all its privileged land utilization pattern and the energy put into its production the returns in any one year are insufficient to cover the imports of consumer goods including food imports needed to feed the populace. Imported food alone which was placed under heavy restrictions in 1977 cost Jamaica $J \$ 52$ million or 61 percent of the funds earned by export of sugar and bananas in that year. Since then imports of food have surged in 1978 while increase in the value of exports, although increased, has been due to the effect of devaluation.

Between 1973 and 1977 , the output of the major agricultural export crops have all been drastically reduced. Increases were only registered for root crops, vegetables, eggs and meat for domestic consumption. Sugar production in 1977 was the lowest in 23 years, less than 40 percent of sugar production in 1967 and similarly for bananas.

The poor performance of the agricultural sector is due to a combination of factors; 1) farms are too small to be economically profitable; 2) the farmers' knowledge of management and husbandry is poor; 3 ) the crops are grown in a mixed stand interplanted with other crops; 4) the crops are often planted on lands 
unsuitable for their production; 5) the historical stigma attached to work on the soil. There is need for a transformation of the agricultural sector through land reform programs already started and providing the technical assistance needed by farmers.

In 1977 the agricultural sector was one of the three sectors to achieve a positive real growth. Its growth of $6 \%$ was confined to the production of domestic root crops and vegetables. The sector contributed less than 9 percent to the Gross Domestic Product in real terms and an approximately 17 percent toward total domestic exports. Of a classifiable labor force of 917,900 in 1977 and a recorded unemployment of $25 \%$ agriculture employed only $27 \%$ of the total labor force.

The Mineral industry was discussed next. It is Jamaica's major foreign exchange earner. It accounted for 70 percent of Jamaica's export earnings, 30 percent of Government non-loan revenues and 11 percent of the gross national product in real terms. The industry in 1977 had the highest growth rate out of the three sectors which had real positive growth, yet it employed less than 1.0 percent of the labor force. Increased production was achieved with fewer employees in 1977 which attests to its capital intensive nature. The industry records the highest weekly earnings for wage-earners of $\$ J 171.00$ for a 36 -hour work week.

Discovery and development of the industry only dates back to 1952. Bauxite reserves are estimated at between 1.2 to 2.0 
bilition metric tonnes, the fourth largest measured reserves of aluminium ore in the world. Bauxite is a soft to moderately hard, fine-grained, porous, earthy material of usually a darkred, reddish-brown colour.

The processing of bauxite follows three stages. Phase I the ore is crushed, washed and dried. Phase II of extracting alumina from the dried ore is often done in Jamaica. Phase III, the final extraction of aluminium from alumina requiring large amounts of power is not done in Jamaica. It takes 2-3 tons of bauxite to produce a ton of alumina and 2-3 tons of alumina to make a ton of aluminium. The real value is in Phase II and III. Jamaica only participates in Phase I and whenever possible in Phase II.

Although the Government of Jamaica has been increasing its ownership and earnings in the mineral industry the industry is nevertheless dominated by North American multi-national enterprises. These giant companies through imports from their parent company provide all their needs of capital, machinery, management and skilled personnel, thereby reducing the multiplier effects of their presence on the island.

In addition bauxite is extracted and processed exclusively by these large aluminium companies and so the ore cannot be sold by Jamaica on the world market as there is no free trade in the ore anywhere in the world.

Next the manufacturing industry was presented. This sector was the largest contributor to the gross domestic product in 
1977 despite a decline of over 5 percent. This sector produces largely for domestic use and employed approximately 8 percent of the total classifiable labor force in 1977. Its earnings from exports of selected manufactured goods was estimated to be $\$ 144$ million which was more than the gross receipts from tourism in that year of sugar and bananas combined. The manufacturing sector average weekly earnings for wage earners is about the third lowest in the island of $\$ 60.41$ for an average work week of 38 hours.

The factors which hamper performance of this sector are discussed. These are: I) small size of the population; 2) low per capita income; 3) Iimited natural resources; 4) dependence on imported raw materials; 5) union activity and worker disagreement; 6) restricted entry to foreign markets; 7 ) economic recession reducing demand for manufacturing inputs; 8 ) migration of the risk-taking entreprenueral class.

The real domestic value is confined to the employment utilized in the production process.

The construction and installation industry was presented next. The activities of this sector includes housing and nonhousing projects. The performance of this sector is a reflection of the level of investment in the economy, the level of fixed capital formation and an indicator of the activities in other sectors.

Between 1975 and 1978 the production of all building materials declined; cement by over $27 \%$; steel by over $32 \%$; 
bagasse board production declined by over $68 \%$ in 1977 and paint by $15 \%$ in 1977. There has been a decline in overall Gross Fixed - Capital Formation of 28\% between 1974 and 1977 which accelerated in the period 1975-1977 to register a decline of $44 \%$.

The contribution of the sector has been on a constant decline since 1975. In 1977 it accounted for only 7 percent of the Gross Domestic Product and employed less than 4 percent of the classifiable labor force in October 1977. Average weekly earnings for wage earners are moderately high at $\mathrm{J} \$ 83.3$ per week for a 40-hour week.

A brief history of tourist development was then given. The industry achieved real significance after the second World War being close to the eastern seaboard of North America and because of the island's natural beauty. Slowly the growth in accommodation far outstripped the increase in visitor arrivals and all-island occupancy fell below breakeven to $29 \%$ in 1977. Financial problems set in, rescued slightly by increased domestic tourism. The decline had increased in proportion since 1975 due to the worldwide recession as a consequence of the oil price increase and the existing social and political climate in Jamaica and the Caribbean in general. For three consecutive years, 1975-1977, the decline in stopovers and since 1976 in cruise passengers got increasingly worse. The pattern has just since 1978 started to reverse due to increased publicity expenditure and reduced adverse press reports. At the same time, 
Jamaica's budgetary allocation for operation of the National Tourist office and promotion has increased from $J \$ 400,000$ in 1955 to J\$8.0 million in 1974 , that is, 6.6 percent, of the gross receipts from tourism for 1974. For the year 1978/79, the allocated budget was $\mathrm{J} \$ 10.4 \mathrm{million}$.

The heavy concentration of Jamaica's tourist market is attested to by the fact that $85 \%$ of the nation's advertising expenditure is spent in North America. However in recent years there has been a slight change in the composition of the Jamaican tourist market. The Anericans although they represent the largest number of visitors have been reducing slowly. The fall-off in Americans is equally balanced by an increase in Canadian and European visitors.

Today the Government of Jamaica has achieved a profitable mix of ownership between public and private and domestic and foreign participation in tourism due to: 1) the deliberate withdrawal of foreign ownership; 2) change in government policy towards greater participation in major productive sectors.

The Government owns fully, or shareholds in $47 \%$ of the hotel rooms on the island. Foreign ownership has declined to 26\% of the hotel rooms, confined most1y to the large international chain operations. There is a total local ownership ratio to foreign ownership of $3: 1$ in favor of Jamaica.

In terms of tourism's contribution to Jamaica, the receipts from the industry appear in the "invisible" section of the balance-of-payments account and are used to offset the age-old 
deficit on the visible merchandise trade. The industry normally competes for second place as an earner of foreign currency with sugar, behind the bauxite/alumina industry. In recent years because the decline in volume of sugar exports has been much more than the decline in gross receipts from tourism, the industry ranked higher than sugar in the receipt of foreign currency. The net receipts from tourism may nevertheless be much lower than sugar as the figures often given for tourism are gross figures of a one-way visitor traffic to Jamaica. The net cost of Jamaicans travelling overseas as visitors has to be subtracted also the leakages from imported goods and services necessary for the industry and the other non-economic, nonpecuniary cost to which it is difficult to assign a value. The fact that the development of tourism's infrastructure and superstructure has been subsidized through incentive legislations, results in the industry providing an inadequate return through taxation and royalty payments. Also the multiplier effect of tourist expenditures is much lower than for sugar and the agricultural industry as the farmers who receive payment have no other choice but to purchase locally to fulfill their needs, whereas much of the foreign currency earned by the tourist industry finds its way into the black market and invariably leaves the island. Together sugar and bananas earned as much foreign currency as net travel receipts of Jamaica but before subtraction for the leakages and other costs to Jamaica. The total value of food export surpassed the gross receipts from tourism. 
In addition tourism and agriculture follow a distinctive pattern. Whenever visitor arrivals decline for a long period as it did between 1975 and 1977 in Jamaica, the agriculture sector improved its performance. As soon as tourism started to recover in 1978 agricultural production declined and the balance of payment worsened. Food imports were up in 1978 by $26 \%$, beverages by $22 \%$, manufactured goods by $32 \%$ and miscellaneous commodities by $19 \%$. In 1978 exports of food declined by $3.4 \%$, beverages by $8 \%$ and miscellaneous commodity exports by $39 \%$. The pattern could be coincidental but travel writers have often claimed tourism kills agriculture. John Bryden was of a similar opinion. The tourist industry could be attracting labor from the agricultural sector who would eventually return to the 1 and during tourism's fall-off period. The tourist industry could also be fanning the flames for increased importations caused by excessive exposure to the consumptive preferences of the visitors.

The tourist industry operates as resort enclaves virtually isolated from the rest of the economy, patterned off an "international tourism style" with an obvious disregard for local architectural designs. Despite numerous calls for "product indigenization", the tourist industry is still dependent on imported managerial skill utilized mostly through the use of management contracts, leases and joint ownership with international hotel operators, imported food and beverage, and technology. 
The industry has a high capital requirement similar to the mining industry, higher than manufacturing, measured on a per-employee basis and provides employment for the same percentage of the total "classifiable labor force" as the mineral industry, less than 1 percent, despite all its promise of utilizing a large proportion of unskilled workers and females which are in abundance in Jamaica. The majority of those service employees in tourism will remain basically unskilled and semi-skilled in comparison to those employed in the more technically-skilled industries such as mining, manufacturing and construction. The average weekly salary for a wage earner in tourism is the second lowest in Jamaica. It averages $\$ 56.16$ for a longer 42-hour work week. It is surpassed only by wages in the distributive sector.

Tourism's role in Jamaica is over-inflated. It contributed the lowest percentage to the Gross Domestic Product in real terms of all the seven major sectors. Even agriculture has a greater scope for absorbing surplus labor than tourism. Chapter IV zeroes in on some of the criticisms of tourism in a post-colonial society and the structure of the tourist industry in Jamaica under management contracts and leasing. The multi-national hotel chains are needed even though the country is aware of their disadvantages such as: 1) unfavorable accounting practices; 2) their technical experience in negotiations compared to locally elected politicians and civil servants. Often the agreements concluded are to the detriment of Jamaica "control is abrogated in the lease contracts, anyway". 
Advertisements are prepared by foreign firms which often leads to the portrayal of an image which is not the most desired for a newly independent nation. Jamaica in 1976 spent more money to attract the average American visitor than the Bahamas which enjoys a higher number of visitor arrivals per annum, and more than the Dominican Repub1ic, Barbados, Trinidad and Curacao, the five Caribbean territories in the survey.

Finally, the chapter considered the impacts of tourism in Jamaica. The benefits of tourism were not ignored but the aim of the chapter was to highlight the most important economic, social, cultural, political and environmental costs of tourism. There are often three major advantages stated: foreign exchange earnings, contribution to employment, and development. However there are major economic effects such as: 1) increase in trade deficits through the increased demand for direct and indirect imports and foreign trave1; 2) increase in black marketing of foreign currencies; 3) competition with agriculture for manpower and land; 4) lack of confidence in local solutions; 5) seasonal excess capacity of hotel facilities; 6) considerable government outlay for tourism infrastructure and promotion. The negative socio-cultural impacts are then described, these are factors which can undermine long-term stability and increase tension in resort areas. The impact include: 1) the replacement of the indigenous way of 1 ife with inappropriate elements of developed societies; 2) increase in class tension between the privileged tourist and local elites as against the 
underprivileged mass; 3) migration to tourism centers and the problems of urbanization; 4) distraction of nationals from seeking legitimate social change; 5) prostitution and venereal diseases.

Tourism in particular stifles political debate in order not to jeopardise confidence in the industry while the environmental impacts relate to the damage to the physical system and the pattern of 1 and use.

Generally the industry does not wish to acknowledge the negative impacts as it is important that the tourist market remains confident. The tourist market is very fickle and there is considerable flexibility within the Caribbean destinations and between the Caribbean and other receiving nations worldwide. The foreign exchange in particular is urgently needed at this time of economic depression, more than ever, and employment in the industry has to be protected, considering the level of recorded and unrecorded unemployment in today's Jamaica.

\section{RECOMMENDATIONS}

Choose the Tourist Market carefully

A desirable first step for Jamaica is to decide on the market it wants, between a quantitative expansion, that is, a mere increase in tourist volume or a qualitative expansion, "fewer but better" tourist market. The decision is between "mass" or "class". There are numerous economic and social implications dependent on the market type attracted. The market 
type will also determine the facility planning needed, in particular whether the tourist industry should remain an enclave in the Jamaican society or be integrated into the society.

Quantitative expansion is achieved through the use of package tours and extensive use of charters. The budgetconscious visitor labelled the mass market produces a greater social costs without a compensatory economic benefit. A considerable proportion of his total vacation expenditure is spent on international transportation and accommodation. Usually he chooses a medium-priced hotel. The result is less receipts and reduced margins for Caribbean operations like Jamaica already experiencing the lowest gross operating profits on a per-room basis and the highest operating expenses worldwide. One has to constantly keep in mind that there is no economic benefit accruing to Jamaica merely from the tourist's presence, but only from his expenditure for goods and services produced 1ocally.

The personality of the mass tourist has to be analysed also for its impacts on the society. He is the type of tourist who seeks all the trimmings of a vacation experience, he demands action, nightlife, excitement. To the extent that extra capital goods, services have to be imported to cater to this sophisticated demand, then the developed countries from which he comes have merely extended their economic activities into the "hinterland" and the Jamaicans are no better off. At the same time the mass tourist is not interested in the problematic realities 
of a Third World developing country such as Jamaica. He has come to relax and enjoy himself particularly as this place has been sold to him as the place to be either by his travel agent or the Government's National Tourist office in his home country. He has invested too much money in this vacation and so he wants his money's worth and wants nothing to spoil it neither the bureaucratic red tape, unfamiliar food and water, inadequate nightlife or even the untrained hotel workers. A tourist enclave is preferable for the mass market if one is to reduce the effect of their presence.

Whenever the "mass" tourists start arriving, they drive out the earlier discovers. One has a choice between catering to this market by outrightly seeking the smaller number of higher quality visitors. This is the qualitative market with a lower social costs and a higher economic benefit. It becomes easier to practice the type of intercultural tourism Jamaica prefers and the visitor being more sophisticated can be integrated into the society. The really wealthy want tranquility and simplicity and may be more sympathetic. In addition Jamaica can seek those groups of people with an affinity to the region and the culture, be selective of the media, the travel writers and organizations with a political interest in the Caribbean and Jamaica's marketing efforts would have to be redirected towards those individuals who seek foreign travel for non-materialistic reasons, then to divert them to the national airline, hotels and other facilities where the country will receive the best economic return. 
Next the country could concentrate on having such a visitor stay longer during off-peak season, hoping to increase his expenditures. This may not be feasible considering the expenditure pattern of visitors varies inversely with the length of stay. The average expenditures per day tends to decrease the longer the stay. He may be induced to increase his expenditure on handicrafts if they are of good quality, variety, wel1-displayed and promoted.

Veit Burger in his study of the economic impact of tourism in Nepal discovered that the import-requirement of budget tourists--pleasure tourists who stay in lodges were only 25 percent below those of luxury tourists--pleasure tourists who use more expensive accommodations. The budget tourists were found to spend a large proportion of total expenditures on transportation to and from Nepal, and miscellaneous items like photographic supplies, books and medicine, al1 of which have a high import content. He concluded that there would be no appreciable reduction in Nepal's import requirement associated with expanded tourism could be realized by catering to one class of tourist rather than another. At the same time luxury tourists spend sufficiently more than budget tourists to generate a larger amount of foreign exchange earnings, and hence, income to nationals than budget tourists. 1

IVeit Burger, The Economic Impact of Tourism in Nepal, an Input-Output Analysis, Cornel1 University, Ph.d., 1978. 
Need to Revitalize the Industry

In order to attract the qualitative market it is necessary that Jamaica builds on its uniqueness. Every destination follows an age-cycle, a pattern of discovery growth, apex and decline, and at each stage it attracts a lower spending category of visitors, in its move from "class" to "mass". Every visitor accepts a certain amount of standardization and uniformity but they want a destination to be much more than beaches, bars and restaurants. Jamaica needs to protect and nurture those elements which earlier attracted the visitors, maintain its appeal, while improving the natural environment and increasing social equity such as housing, health services and employment.

Tourism is also very competitive, therefore Jamaica should keep abreast of market trends in accommodations and facilities as modern transportation today closes the gap between distant regions and countries. Constant market research is recommended and accurate forecasts of tourist requirements. Tourism could be made into a more meaningful inter-cultural experience with Jamaica demonstrating its harmonious mix of peoples, races and culture, its superiority in social advance emphasising the individual and his right of expression.

Enrich tourist facilities with the architectural heritage that is ours and further exploit the current wave of nostalgia among visitors for antiques and wicker in seeking to improve the tourist experience. Since a larger percentage of the 
the tourist budget is eaten up air travel and accomodation, a "sunk cost" the pleasure they get out of a vacation is derived largely from their participation in local recreational activities. There is therefore a need for diversification and upgrading of the island's entertainment and available instruments for familiarizing the tourist with local art, craft and music. There is need for promotion of less energy consuming vehicles such as rent-a-bicycles and motorbikes instead of cars in tourist areas.

Improvement of Services

Efficient professional managers are a necessity. Jamaica should therefore monitor the quality of staff training. Better educated personnel are more courteous and understanding of visitor needs and will enhance the quality of service delivered. Satisfied vacationers are the cheapest and most effective vehicles of "word-of-mouth" advertising. Jamaica should specify the percentage share and types of positions nationals ought to assume in the large hotel accommodations and every effort made to develop indigenous management ski11s.

It may be necessary to abolish individual tipping as is being practiced in some hospitality operations in the developed countries. The entire gratuity would be built into the guest bill and the guest given a choice of whether or not he wishes to pay this extra sum. At the same time worker benefits and promotions could be improved to provide the needed incentives. 
Service to visitors can be improved through the provision of visitor information manuals for hotel workers, tour guides and taxi-drivers. Accurate information on Jamaica, its history, and culture would be presented and illustrated for easy comprehension. A system of 1 icensing examinations and refresher course for updated information could be instituted. Elementary conversational Spanish could at a later date be built into the original program. The program provides additional opportunities and seeks to ensure that accurate information is conveyed at all times.

Government incentives to tourism

There is need for uniform hotel concessions throughout the Caribbean to reduce cut-throat competition in providing incentives to developers of hotel accommodations. The concessions and incentives given to investors have been over-generous and exceeded the stimulus required. Each should be individually evaluated for their net economic benefits to Jamaica. Often the loans to tourist enterprises are subsidized at rates reflecting the scarcity of capital and inflation. The benefits which accrues to Jamaica should be much greater than the financial gains accruing to the private resort operators. The cost to Jamaica is the loss of potential revenue and an inadequate return from tourists to cover their share of the infrastructure costs. 


\section{Domestic Tourism}

Domestic tourism caters to those who do not have the means for foreign travel and has proved to be an effective method of strengthening national sentiment and redistributing income among locals. It reduces excess capacity and seasonality by using an infrastructure already existing. However domestic tourists tend to use more medium-quality, lower-priced accommodation, require less imported food and beverage and labor. This means that the high-priced, more ostentatious hotels will be more dependent on foreign tourist traffic and will have to achieve a far higher average occupancy during the peak tourist season in order to realise an acceptable all-year occupancy and profitability.

Import Substitution

A balanced amount of import substitution should be achieved with Jamaica stressing material goods only to the extent it can be supplied locally.

It is extremely important that there be increased linkages between the agricultural sector and the touristindustry to reduce unnecessary leakages as have been pointed out by numerous Jamaican and Caribbean writers. Communication between the two sectors should first be improved so that the items required and specifications can be met and be made available as needed. With more efficient production of food and beverage inputs, it may be cheaper for Jamaica to supply her neighbouring Caribbean tourism-dependent islands. 
To achieve this end it will be necessary to reduce the historical stigma against working the soil by upgrading the skill levels of those employed in the industry through the Jamaica Agricultural School, and through improved technology.

One has to be careful with a policy of import substitution, as a visitor values the quality of service he receives and if he can be induced to spend more by supplying his request for imported goods, then it may be advantageous to have the goods available.

In addition a system of import licensing could be devised whereby foreign exchange permits would be issued to Hotel and Travel operations to allow them some small amount of freedom to pay for the imported goods and services necessary for their particular operation. Their foreign exchange allottment would be individually calculated as a small percentage of the foreign currencies which the individual operation had submitted to the Central Bank for conversion to local currency. This would also be an added incentive for their administrative personnels to control the flow of foreign currencies through their enterprises as this will be the yardstick by which their monthly or quarterly foreign exchange allottment would be calculated.

The replacement of foreign ownership and control with local private enterprise and the Jamaican Government is in the best interest of the island. However if the economic benefits from tourism are restricted to the selfish elites in ownership and control positions, then there has been local ownership without a corresponding equal spread of income. This problem needs to be redressed. 


\section{CONCLUSION}

The objective of this paper has been to present information on the contribution of tourism compared to the other major industrial sectors in Jamaica, to assist the island's planners in their decision as to whether or not tourism can be relied on to provide the economic development needed, and to suggest possible strategies and policies to derive increased benefits from tourism while minimizing the negative impacts.

Tourism is an effective method of earning foreign exchange but one that has numerous costs attached depending on the tourist market catered to. Even when the degree of local control is increased, the leakages of gross revenue reduced, and a more socially and culturally acceptable tourism is practiced, Jamaica's tourist industry will still be faced with the problem of dependency on the fickle tourist market, and economic fluctuations in the tourist-gerating nations. Many of the negative social impacts will continue.

Tourism should be developed to provide the foreign exchange needed but the island needs to start concentrating its energies in those areas where the benefits to the society are more widespread. 
Books and Collections of Papers

Bryden, John. Tourism and Development: A Case Study of the Commonwealth Caribbean. Cambridge: Cambridge Univer. sity press, 1973.

Demas, William. Change and Renewal in the Caribbean. Barbados: CCC Publishing House, 1975 .

Doxey, George V. The Tourist Industry in Barbados: A Socio-economic Assessment. Kitchener, Ontario: Dusco Graphics, 1971 .

Gray, H. Peter. International Trave1 - International Trade. Lexington, Massachusetts: Heath-Lexington, 1970 .

Jainarain, Iserdeo. Trade and Underdevelopment: A Study of the Sma11 Caribbean and Large Multi-national Corporations. Guyana: Institute of Development Studies,

Kuper, Adam. Changing Jamaica. Kingston Publishers, Kingston, 1976.

Lundberg, Donald. The Tourist Business. 3rd ed. Boston: Cahners, 1976.

MacCanne11, Dean. The Tourist: A New Theory of the Leisure Class. New York: Schocken, 1976.

McIntosh, Robert. Tourism: Principles, Practices, Philosophy Columbus, Ohio: Isrid, 1976.

Manley, Michael. The Politics of Change. London: Andre Deutsh, $197 \overline{4}$.

Robinson, H. A Geography of Tourism. London: MacDonald and Evans, 1976.

Schumacher, E.F. Small is Beautiful: Economics as if People Mattered. New York: Harper and Row, 1973

Shivji, I.G., ed. Tourism and Socialist Development. Dar es Salaam: Tanzania Publishing House, 1973.

Turner, Louis, and Ash, John. The Golden Hordes: International Tourism and the Pleasure Periphery. London:

Constable, 1975 .

Wahab, Salah. Wahab on Tourism Management. London: Tourism International Press, 1975.

Young, Sir George. Tourism: Blessing or Blight? Penguin, London, England, 1973. 
Prticles and Published Papers

"American Pleasure Travel". Cornel1 Hotel and Restaurant Administration ouarter1y $13: 3,1972, \quad$ P. . -16.

Archer, Brian. "Domestic Tourism As A Development Factor". Anna1s of Tourism Research. Jan/Mar. 1978. Vol. V. No. I.

Be11, John. "The Caribbean Hotel Industry--Problems and Possibilities." Caribbean Issues $2: 1$, 1976, pp48-55.

Blumenthal, Ralph. "The Caribbean". Signature. November $1976, \quad \mathrm{pp} .33-36$.

Bugnicourt, Jacques. "Tourism: The other Face". Development Forum $5: 6,1977$, P.8.

Cumper, G.E. "Tourist Expenditure In Jamaica, 1958" Socia1 and Economic Studies. $8 / 1959 ; \quad$ p.p. 287-310

"Currency Changes, Exchange Rates, and Their Effects on Tourism". International Tourism Quarterly, no.4 1975 , pp. 34-35.

Caribbean Year Book 1978/79.

Eyster, James J. "Economic Development and Public Policy: Tourism as an Alternative". Cornell Hotel and Restaurant Administration Quarter1y. 17:3, 1976, pp. 22-30.

Edelman, Klaus. "Major Problems and Tourism Growth in Developing Countries". Annals of Tourism Research, Sept./Oct. 1975, Vol III, No. I.

Goffe, Peter. "Development Potential of International Tourism". Corne11 Hotel and Restaurant Administration Quarterly $16: 3,1975, \mathrm{pp} .24-31$.

Gray, Peter. "The Demand for International Travel by the United States and Canada". Internationa1 Economic Review 7, 1966, pp.83-92.

Hiller, Herbert I. "Commentary on Things Tourismic". Caribbean Review $7: 1,1975$, p.7.

Hi11s, Theo and Lundgren, Jan. "The Impact of Tourism in the Caribbean--A Methodological Study". Annals of Tourism Research 4, 1977, pp. $248-267$.

Hudman, Lloyd E. "Tourist Impacts: The Need For Regional Planning". Annals of Tourism Research, Jan/Mar 1978. Vol. V No. I. 
Articles and Published Papers continued.

International Union of Official Travel Organizations, "The Impact of International Tourism on the Economic Development of the Developing Countries". Geneva, 1975 .

Jud, Donald. "Tourism and Economic Growth in Mexico Since $1950^{\circ}$. Inter-American Economic Affairs. $28: 1,1974$, pp. $19-43$.

Keller, Dale. "The Hotel of Tomorrow". Cornell Hotel and Restaurant Administration Quarteriy. 17:4, 1977, pp.49-55.

Linton, Neville. "Tourism In The Commonwealth Caribbean-An Overview". Caribbean Issues 2:1, 1976, pp.36-47.

Levitt, Kari and Best, Lloyd. "Character of Caribbean Economy". Caribbean Economy, Institute of Social and Economic Research. 1975, pp.36-47.

Mings, Robert C. "The Struggle for Cultural Autonomy Among Developing Nations: The Case of Puerto Rico and Its Tourist Industry". Caribbean Quarter1y 14:3, 1968, pp. $7-21$

Morgan, Peter. G. "Barbados Encourages Local Tourism Investment". Cornel1 Hotel and Restaurant Administration Quarterly 17:2, 1976, pp.14-17.

Matthews, Harry. G. "Radicals and Third World Tourism, A Caribbean Focus" Annals of Tourism Research. Oct/ Dec. 1977, Vol. V.

"National Report No. 33: Mexico". International Tourism Quarterly, No.3., 1976, pp.25-38.

Overseas Geological Surveys, Mineral Resources Division. "Bauxite, Alumina and Aluminium", Her Majesty's. Stationery Office, London. pp. 110-115.

Pollard, H.J. "Tourism: The Growth Industry of the Caribbean". Geography 61, 1976, pp.102-07.

Stock, Robert. "Political and Social Contributions of International Tourism to the Development of Israel", Annals of Tourism Research. Sept/Oct. 1977, Vol. V.

Waters, Somerset and Patterson, William. "World Tourism in Perspective". ICTA: Domestic and International Tourism. $1977, \mathrm{pp} .30-45$. 
Articles and Published papers continued.

Taylor, Frank, F. "The Tourist Industry in Jamaica, 1919$1939^{\prime \prime}$. Social and Economic Studies 22, 1973 , pp.205-

Theuns, H.L. "Notes on the Economic Impact of International Tourism in Developing Countries". Tourist Review $31: 3,1976, \mathrm{pp} .2-10$.

Turner, Louis. "The International Division of Leisure: Tourism and The Third World". World Development 4 , 1976 , pp. 253-60.

Vogt, Jay W. "Wandering: Youth and Travel Behavior". Annals of Tourism Research. Sept./Oct. 1976, Vol. IV,

Walah, S.E.A. "Aspects of Organization For Tourism at the Destination End". Tourist Review, 30:2, 1975 , pp.49-57.

Wa11, Geoffrey and A1i, Inshan Maccum. "The Impact of Tourism In TRINIDAD and Tobago". Annals of Tourism Research. Sept.oct. 1977. Vol. V.

Yesawich, Peter and Duncan, John III. "A Survey of Attitudes of U.S. Travel Agents". Cornell Hotel and Restaurant Administration Quarteriy, May Ty75.. 
Reports, Unpublished Papers, Goverment Publications, and other Sources

ASTA Trave1 News. Trave1 $176 / 1-77:$ The Big Picture. New York. ASTA Travel News 1976.

A.STA Travel News, Trave1 177/78: The Big Picture. New York. ASTA Travel News 1977.

Bank of JAMAICA Quarterly and Monthiy Bulletins. Several issues.

Brown Headley, "The Impact of the Tourist Industries on the Agricultural Sectors: The Competition for Resources and the Market For Food Provided by Tourism." Unpublished research paper, National Planning Agency, Kingston, Jamaica 1975.

Britton, Robert A. "International Tourism and Indigenous Development Objectives: A Study with Special Reference to the West Indies". Ph.D. dissertation, University of Minnesota, 1978.

Burger, Veit. "The Economic Impact of Tourism in Nepal, An Input-Output Analysis." Ph.D dissertation, Corne11 University, 1978.

Caribbean Tourism Association, Visitor Statistics 1976. New York: Caribbean Tourism Association 1977.

Christian Action For Development in The Caribbean (CADEC). The Role of Tourism in Caribbean Development: Report of the Ecumenical Consultation. Study Paper no.8.

Consumer Price Indices, Department of Statistics JAMAICA. Several monthly issues. Demographic Statistics 1977 , Department of Statistics, Jamaica.

Discover America Travel Institute. "Discover America Package Tour Handbook". Washington: Discover America Travel Institute 1976.

Economic and Social Survey, Jamaica 1977. National Planning Agency.

Economic and Social Survey, Jamaica 1976. National Planning Agency.

Employment, Earnings and Hours In Large Establishments in 1977. Department of Statistics, Jamaica.

External Trade, 1977. Department of Statistics Jamaica. 
Reports, Unpublished Paper, Government Publications, and other Sources continued.

Facts on Jamaica Tourism 1960-1972. Department of Statistics. Greenwood, Davydd. "Culture by the Pound: An Anthropological Perspective on Tourism As A Cultural Commoditization". Paper presented at the 73 rd meeting of the American Anthropological Association, Mexico City November 1974. pp. 19-24.

Government of JAMAICA. Five Year Development Plan 1978-82. National Planning Agency.

Horwath and Horwath International Worldwide Lodging Industry 1975 edition, New York: Horwath and Horwath International, 1975 .

Kanellakis, Vassilois. "International Tourism: Its Significance and Potential as an Instrument for the Economic Development of Greece". Ph.D dissertation, Kansas University, 1975.

Nettleford, Rex. "Cultural Impact of Tourism" Address presented to the Seminar "Tourism and Its Effects". Nassau, Bahamas, November 1975, pp. 24-28.

Plog, Stanley C. "Why Distination Areas Rise and Fall in Popularity". Paper presented at a meeting of the Southern California Chapter of the Travel Research Association, 10 October 1972.

Sindlinger, Albert E. Sindlinger Air Travel Demand Study presentation for the Eastern Council of Trave1. Research, Dec. 7, 1971.

Statistical Abstract 1977, Department of Statistics

Statistical Bulletin of the OAS. Washington D.C., JanuaryMarch 1979.

Statistical Yearbook of JAMAICA, 1977, Department of Statistics. 


\section{VITA}

Title of Thesis: International Tourism: Is this the Answer to Jamaica's Developmental Problems?

Full Name: Geli M. Eldemire

Place and Date of Birth: Kingston, Jamaica - June 1952.

Elementary and Secondary Education:

Elementary Education gained at Avondale Preparatory School.

Earned the G.C.E. Ordinary Levels Certificate from Merl Grove High School and G.E.C. Advanced Level Certificate from Excelsior High School.

Colleges and Universities - Years Attended and Degrees:

(1) University of the West Indies, Jamaica, 1971-1974 - BSC - Business Administration

(2) Florida International University, Miami, Florida 1977-1979 - MSc - Hotel and Restaurant Management

Membership in Learned or Honorary Societies:

(1) Hote1, Food and Travel Association

(2) International Students

(3) Jamaica School of Dance

Publications: None

Major Department: Hospitality Management

Minor(s): International Travel

Personnel Administration

Date: September 1979 